\title{
Groundwater-Quality Data from the National Water-Quality Assessment Project, May 2012 through December 2013
}

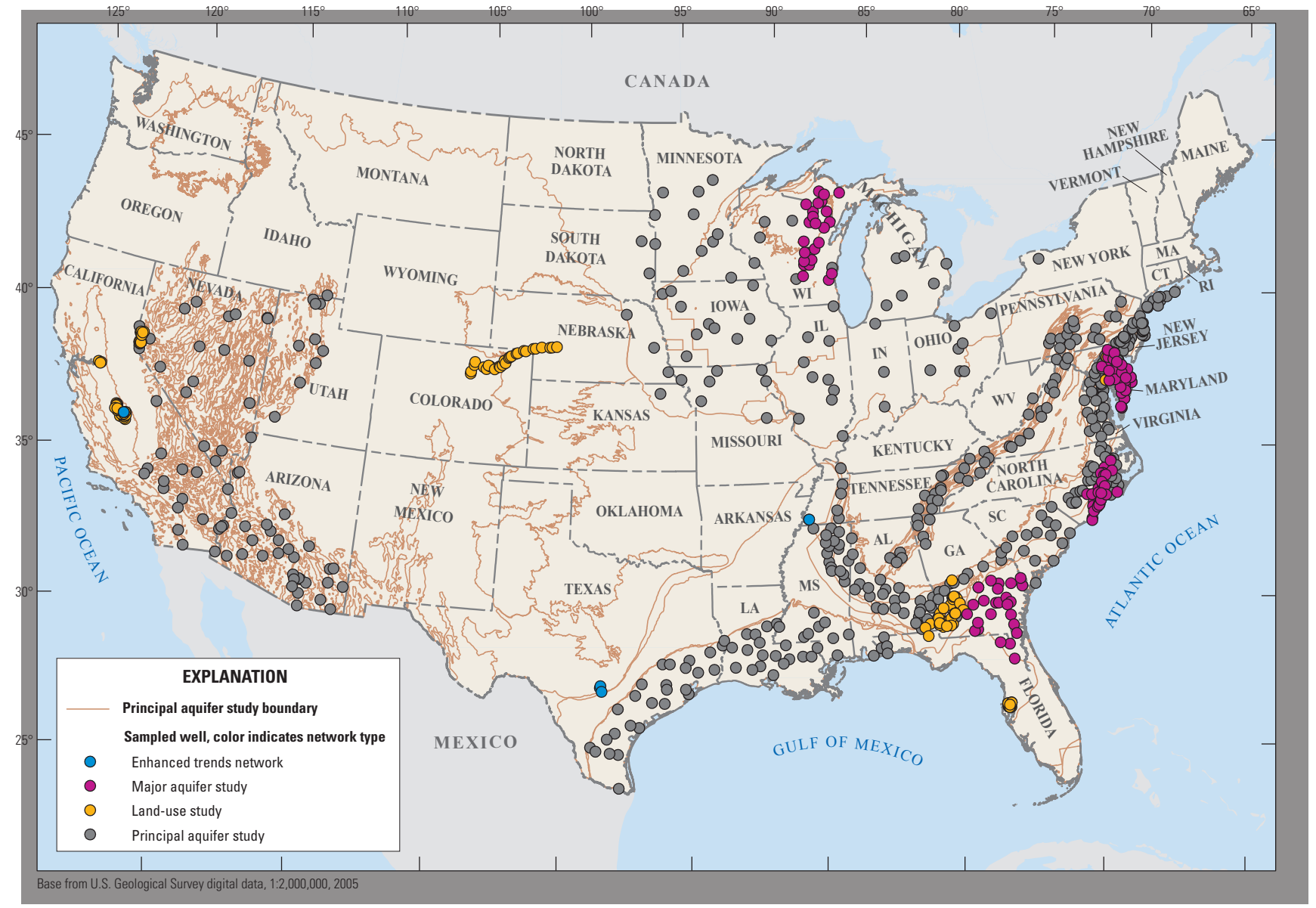

Data Series 997

Version 1.1, November 2016 
Front cover: Map shows Groundwater study networks and wells sampled as part of the U.S. Geological Survey National Water-Quality Assessment Project from May 2012 through December 2013 for which water quality data are included in this report. Modified from figure 1. 


\section{Groundwater-Quality Data from the National Water-Quality Assessment Project, May 2012 through December 2013}

By Terri L. Arnold, Leslie A. DeSimone, Laura M. Bexfield, Bruce D. Lindsey, Jeanine R. Barlow, Justin T. Kulongoski, MaryLynn Musgrove, James A. Kingsbury, and Kenneth Belitz

Data Series 997

Version 1.1, November 2016 


\title{
U.S. Department of the Interior SALLY JEWELL, Secretary
}

\section{U.S. Geological Survey Suzette M. Kimball, Director}

\author{
U.S. Geological Survey, Reston, Virginia: 2016 \\ First release: June 2016 \\ Revised: November 2016 (ver. 1.1)
}

\begin{abstract}
For more information on the USGS - the Federal source for science about the Earth, its natural and living resources, natural hazards, and the environment—visit http://www.usgs.gov or call 1-888-ASK-USGS.

For an overview of USGS information products, including maps, imagery, and publications, visit http://www.usgs.gov/pubprod/.
\end{abstract}

\author{
Any use of trade, firm, or product names is for descriptive purposes only and does not imply endorsement by the \\ U.S. Government. \\ Although this information product, for the most part, is in the public domain, it also may contain copyrighted materials \\ as noted in the text. Permission to reproduce copyrighted items must be secured from the copyright owner. \\ Suggested citation: \\ Arnold, T.L., DeSimone, L.A., Bexfield, L.M., Lindsey, B.D., Barlow, J.R., Kulongoski, J.T., Musgrove, MaryLynn, \\ Kingsbury, J.A., and Belitz, Kenneth, 2016, Groundwater quality data from the National Water-Quality Assessment \\ Project, May 2012 through December 2013 (ver. 1.1, November 2016): U.S. Geological Survey Data Series 997, 56 p., \\ http://dx.doi.org/10.3133/ds997.
}

ISSN 2327-638X (online) 


\section{Contents}

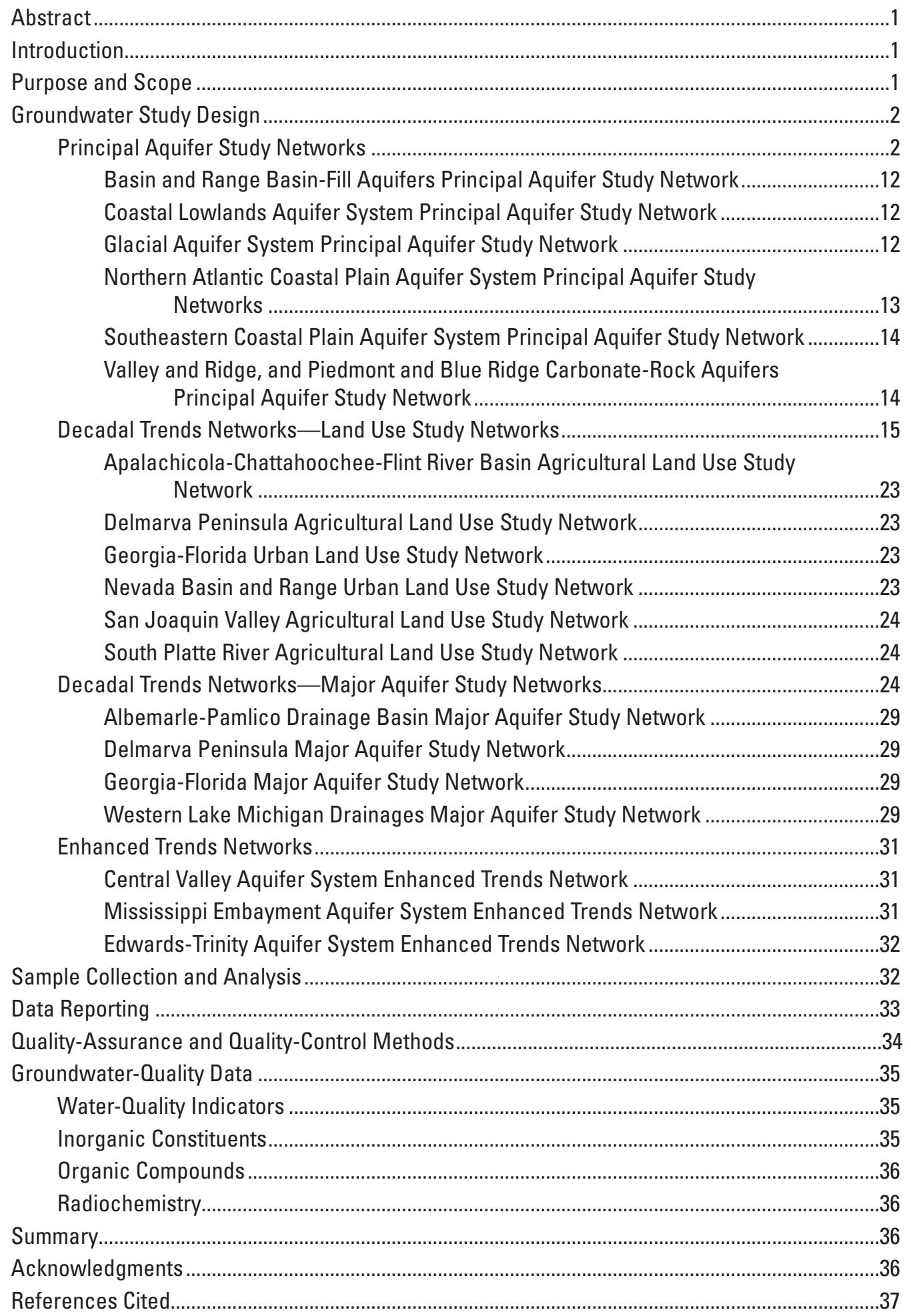


Appendix 1. High-Frequency Data from Enhanced Trends Networks ...........................................46

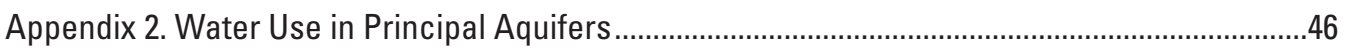

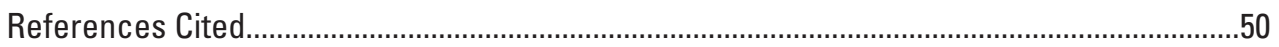

Appendix 3. Quality-Control Data and Analysis of Blank Samples...................................................51

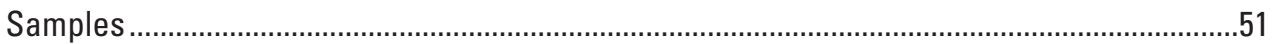

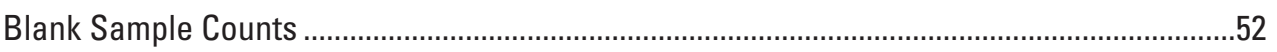

Constituent Concentrations in Blank Samples ……………....................................................52

Appendix Tables 3-2 through 3-15 are available for download at http://dx.doi.org/10.5066/F7H03X18 ................ (A list of table titles is found on page 53)

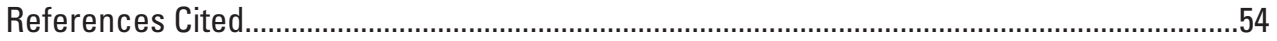

Appendix 4. Well depth and open interval by study network .......................................................5

\section{Figures}

1. Map showing groundwater study networks and wells sampled as part of the U.S. Geological Survey National Water-Quality Assessment Project from May 2012 through December 2013 for which water quality data are included in this report............3

2. Map showing study area and wells sampled as part of the Basin and Range basin-fill aquifers principal aquifer study network (bnrfpas1) for the U.S. Geological Survey National Water-Quality Assessment Project, June through November 2013.

3. Map showing study area and wells sampled as part of the Coastal Lowlands aquifer system principal aquifer study network (clowpas1) for the U.S. Geological Survey National Water-Quality Assessment Project, May through December 2013

4. Map showing study area and wells sampled as part of the glacial aquifer system principal aquifer study network (glacpas1) for the U.S. Geological Survey National Water-Quality Assessment Project, July through December 2013

5. Map showing study area and wells sampled as part of the Northern Atlantic Coastal Plain aquifer system principal aquifer study network (nacppas1) in New Jersey, New York, Delaware, and Maryland for the U.S. Geological Survey National Water-Quality Assessment Project, May through October 2012.

6. Maps showing study area and wells sampled as part of the Northern Atlantic Coastal Plain aquifer system principal aquifer study network (nacppas2) in Virginia and North Carolina for the U.S. Geological Survey National Water-Quality Assessment Project, July through November 2013. A, Study area and wells in the Piney Point-Castle Hayne aquifers. $B$, Study area and wells in the Potomac-Magothy aquifers

7. Map showing study area and wells sampled as part of the Southeastern Coastal Plain aquifer system principal aquifer study network (secppas1) for the U.S. Geological Survey National Water-Quality Assessment Project, June through September 2013...

8. Map showing study area and wells sampled as part of the Valley and Ridge, and Piedmont and Blue Ridge carbonate-rock principal aquifer study network (vpdcpas1) for the U.S. Geological Survey National Water-Quality Assessment Project, July through October 2013

9. Map showing study area and wells sampled as part of the ApalachicolaChattahoochee-Flint River Basin agricultural land use study network (acfbluscr3) for the U.S. Geological Survey National Water-Quality Assessment Project, August through September 2013. 
10. Map showing study area and wells sampled as part of the Delmarva Peninsula agricultural land use study network (dlmvluscr1) for the U.S. Geological Survey National Water-Quality Assessment Project, July through September 2012.

11. Map showing study area and wells sampled as part of the Georgia-Florida urban land-use study network (gafllusrc1) near Tampa, Florida, for the U.S. Geological Survey National Water-Quality Assessment Project, July through November 2012 ......18

12. Map showing study area and wells sampled as part of the Nevada Basin and Range urban land use study network (nvbrlusrc1) near Reno and Carson City, Nevada, for the U.S. Geological Survey National Water-Quality Assessment Project, April through June 2013.

13. Maps showing study area and wells sampled as part of the San Joaquin agricultural land use study network (sanjlusor1a) for the U.S. Geological Survey National Water-Quality Assessment Project, July 2013. A, Northern part of the study area, near Stockton, California. B, Southern part of the study area near Fresno, California

14. Map showing study area and wells sampled as part of the South Platte River agricultural land use study network (spltluscr1) for the U.S. Geological Survey National Water-Quality Assessment Project, June through August 2013

15. Map showing study area and wells sampled as part of the Albemarle-Pamlico major aquifer study network (albesus7) for the U.S. Geological Survey National Water-Quality Assessment Project, June through September 2013.

16. Map showing study area and wells sampled as part of the Delmarva Peninsula major aquifer study network (dlmvsus1) for the U.S. Geological Survey National WaterQuality Assessment Project, June through August 2013.

17. Map showing study area and wells sampled as part of the Georgia-Florida major aquifer study network (gaflsus4) for the U.S. Geological Survey National WaterQuality Assessment Project, June through September 2013

18. Map showing study area and wells sampled as part of the Western Lake Michigan drainages major aquifer study network (wmicsus2) for the U.S. Geological Survey National Water-Quality Assessment Project, July through August 2013.

19. Map showing study areas and wells sampled as part of the enhanced trends networks for the U.S. Geological Survey National Water-Quality Assessment Project, September 2013 through December 2013

\section{Tables}

The American Standard Code for Information Interchange (ASCII) text files of tables 1-11 are available for download at http://dx.doi.org/10.5066/F7H03X18.

1. Identification, location, sampling, and construction information for wells sampled for the U.S. Geological Survey National Water-Quality Assessment Project, May 2012 through December 2013.

2. Constituent primary uses and sources; analytical schedules and sampling period; USGS parameter codes; comparison thresholds; reporting levels; and number of analyses, detections, and detections above the reporting level for wells sampled for the U.S. Geological Survey National Water-Quality Assessment Project, May 2012 through December 2013.

3. Water-quality indicators in groundwater samples collected by the U.S. Geological Survey National Water-Quality Assessment Project, May 2012 through

December 2013. 
4. Nutrients and dissolved organic carbon in groundwater samples collected by the U.S. Geological Survey National Water-Quality Assessment Project, May 2012 through December 2013.

5. Major and minor ions in groundwater samples collected by the U.S. Geological Survey National Water-Quality Assessment Project, May 2012 through December 2013.

6. Trace elements in groundwater samples collected by the U.S. Geological Survey National Water-Quality Assessment Project, May 2012 through December 2013.

7. Volatile organic compounds (VOCs) in groundwater samples collected by the U.S. Geological Survey National Water-Quality Assessment Project, May 2012 through November 2012.

8. Volatile organic compounds (VOCs) in groundwater samples collected by the U.S. Geological Survey National Water-Quality Assessment Project, April 2013 through December 2013.

9. Pesticides in groundwater samples collected by the U.S. Geological Survey National Water-Quality Assessment Project, May 2012 through November 2012.

10. Pesticides in groundwater samples collected by the U.S. Geological Survey National Water-Quality Assessment Project, April 2013 through December 2013.

11. Radionuclides in groundwater samples collected by the U.S. Geological Survey National Water-Quality Assessment Project, May 2012 through December 2013. 


\section{Conversion Factors}

U.S. customary units to International System of Units

\begin{tabular}{lcl}
\hline \multicolumn{1}{c}{ Multiply } & By & \multicolumn{1}{c}{ To obtain } \\
\hline inch (in.) & Length & \\
foot (ft) & 2.54 & centimeter $(\mathrm{cm})$ \\
mile (mi) & 0.3048 & meter $(\mathrm{m})$ \\
\hline & 1.609 & kilometer $(\mathrm{km})$ \\
\hline square mile $\left(\mathrm{mi}^{2}\right)$ & Area & \\
\hline & 2.590 & square kilometer $\left(\mathrm{km}^{2}\right)$ \\
\hline million gallons per day $(\mathrm{Mgal} / \mathrm{d})$ & Flow rate & cubic meter per second $\left(\mathrm{m}^{3} / \mathrm{s}\right)$ \\
billion gallons per day (Bgal/d) & 0.04381 & cubic meter per second $\left(\mathrm{m}^{3} / \mathrm{s}\right)$ \\
\hline & 43.81 & \\
\hline picocurie per liter $(\mathrm{pCi} / \mathrm{L})$ & Radioactivity & becquerel per liter $(\mathrm{Bq} / \mathrm{L})$ \\
\hline
\end{tabular}

Temperature in degrees Celsius $\left({ }^{\circ} \mathrm{C}\right)$ may be converted to degrees Fahrenheit $\left({ }^{\circ} \mathrm{F}\right)$ as follows:

$$
{ }^{\circ} \mathrm{F}=\left(1.8 \times^{\circ} \mathrm{C}\right)+32
$$

\section{Supplemental Information}

Specific conductance is given in microsiemens per centimeter at 25 degrees Celsius $\left(\mu \mathrm{S} / \mathrm{cm}\right.$ at $\left.25^{\circ} \mathrm{C}\right)$.

Concentrations of chemical constituents in water are given in either milligrams per liter (mg/L), micrograms per liter $(\mu \mathrm{g} / \mathrm{L})$, or nanograms per liter $(\mathrm{ng} / \mathrm{L})$.

Activities for radioactive constituents in water are given in picocuries per liter (pCi/L).

This report contains Chemical Abstracts Service (CAS) Registry Numbers ${ }^{\circledR}$, which is a Registered Trademark of the American Chemical Society. The CAS recommends the verification of the CAS Registry Numbers through CAS Client Services ${ }^{S M}$

\section{Datum}

Vertical coordinate information is referenced to either the North American Vertical Datum of 1988 (NAVD 88) or the National Geodetic Vertical Datum of 1929 (NGVD 29) and is specified in tables where vertical datum is reported.

Altitude, as used in this report, refers to distance above the vertical datum. 


\section{Abbreviations}

ASCII American Standard Code for Information Interchange

EPA U.S. Environmental Protection Agency

ETN enhanced trends network

HHBP human-health benchmark for pesticides

ID identification

LRL laboratory reporting level

LT-MDL long-term method detection level

LUS land use study

MAR Midwestern agricultural region

MAS major aquifer study

MCL maximum contaminant level

MDL method detection level

NAWQA National Water-Quality Assessment

PAS principal aquifer study

OC quality control

ssLc sample-specific critical level

ssMDC sample-specific minimum detectable concentration

USGS U.S. Geological Survey

VOC volatile organic compound 


\title{
Groundwater-Quality Data from the National Water-Quality Assessment Project, May 2012 through December 2013
}

\author{
By Terri L. Arnold, Leslie A. DeSimone, Laura M. Bexfield, Bruce D. Lindsey, Jeanine R. Barlow, Justin T. \\ Kulongoski, MaryLynn Musgrove, James A. Kingsbury, and Kenneth Belitz
}

\section{Abstract}

Groundwater-quality data were collected from 748 wells as part of the National Water-Quality Assessment Project of the U.S. Geological Survey National Water-Quality Program from May 2012 through December 2013. The data were collected from four types of well networks: principal aquifer study networks, which assess the quality of groundwater used for public water supply; land-use study networks, which assess land-use effects on shallow groundwater quality; major aquifer study networks, which assess the quality of groundwater used for domestic supply; and enhanced trends networks, which evaluate the time scales during which groundwater quality changes. Groundwater samples were analyzed for a large number of water-quality indicators and constituents, including major ions, nutrients, trace elements, volatile organic compounds, pesticides, and radionuclides. These groundwater quality data are tabulated in this report. Quality-control samples also were collected; data from blank and replicate quality-control samples are included in this report.

\section{Introduction}

The National Water-Quality Assessment (NAWQA) Project of the U.S. Geological Survey (USGS) National Water-Quality Program was fully implemented in 1991 and operates in about 10-year long cycles. The NAWQA Project began its third cycle of studies in 2013. The NAWQA Project is designed to describe current water-quality conditions of the Nation's freshwater streams, rivers, and aquifers; describe how water quality is changing with time; improve understanding of the natural and human factors that affect water quality; forecast future water-quality conditions; and assess effects of water-quality stressors on aquatic ecosystems (Rowe and others, 2010, 2013). For the third cycle of studies, the NAWQA Project design was modified to include the last two goals listed above.
The NAWQA Project groundwater assessments focus on the quality of groundwater used for public and domestic drinking-water supply; groundwater susceptibility to degradation; effects of natural and human factors on source, transport, and flux of contaminants to and within aquifers; groundwaterquality contributions to surface-water quality; and current and historic management practices relative to groundwater quality. Groundwater quality is studied at multiple scales: locally, regionally, and nationally. The primary regional scale at which groundwater data are collected during the third decade of the NAWQA Project is the scale of the principal aquifers (Burow and Belitz, 2014). A principal aquifer is defined as a regionally extensive aquifer or aquifer system that has the potential to be used as a source of potable water. Principal aquifers were selected for assessment based on their national ranking as sources of water used for public supply (appendix 2).

Groundwater-quality data collected by the NAWQA Project during each year will be published in annual data series reports, like this report. Data series reports are available online through the USGS publications warehouse (http://pubs. er.usgs.gov/).

\section{Purpose and Scope}

The purpose of this report is to present the analytical results of the groundwater-quality samples collected in 2012 and 2013 as part of the third cycle of NAWQA Project studies and provide brief descriptions of the groundwater-quality study networks for use in subsequent publications. Types of analyses include the following: water-quality indicators, major and minor ions, nutrients, volatile organic compounds (VOCs), pesticides, and radionuclides. The water-quality data are presented as tables in the format of tab-delimited American Standard Code for Information Interchange (ASCII) text files, which may be imported into spreadsheet, database, or statistical software for manipulation and analysis. 


\section{Groundwater Study Design}

Groundwater-quality samples are collected from wells that are organized into networks for study purposes (fig.1). A network is a group of wells that have been selected for sampling based on specific hydrogeologic conditions, land use, or other design criteria. Many networks have wells that were sampled in multiple decadal sampling periods; however, if a network well was damaged or destroyed, had too little water, or the current owner would not permit sampling, then that well was not resampled. Maps and tables in this report have well identification (ID) numbers assigned by the NAWQA Project to identify the wells (table 1); since some wells could not be resampled, some networks do not have consecutively numbered NAWQA Project ID numbers in this report. As used on maps showing network-specific information (figs. 2-19), the ID numbers are shown either as numbers only or a combination of numbers and letters which indicate a particular well within the network. The NAWQA well identification number listed in table 1 is a combination of the network name and the NAWQA Project ID. Data from four primary types of groundwater study networks are presented in this report (fig. 1): principal aquifer study (PAS), land-use study (LUS), major aquifer study (MAS), and enhanced trends networks (ETN).

Wells in PAS, LUS, and MAS networks were randomly selected using an equal-area grid to divide up the study area (Scott, 1990). The equal-area grid method allows for evaluation of constituent concentrations at a regional scale (Belitz and others, 2010). For LUS networks, random potential sampling locations in each grid cell were generated by a software program (Scott, 1990), and monitoring wells were subsequently installed as near to the randomly selected locations as possible. Study areas for LUS networks included the areal extents of the primary aquifer and a specific land use (for example, orchard) of interest. For MAS and PAS networks, one well per grid cell was randomly selected from a population of existing domestic or public-supply wells (Gilliom and others, 1995; Scott, 1990). For PAS networks, one publicsupply well was selected for sampling within each grid cell where possible; however, if a well was not available within a grid cell (for example, because permission to sample could not be obtained), an additional well was selected within an adjacent grid cell, not to exceed four wells in two adjacent grid cells. Equal-area grids used for network design only are shown on figures relating to PAS networks because the grids are not available for LUS or MAS networks designed during the first two decades of sampling.

The ETN wells are selected from existing networks where possible. The wells are in hydrogeologic settings where changes in hydrologic conditions, land use, or contaminant inputs are expected to be quickly reflected in groundwater.

\section{Principal Aquifer Study Networks}

The PAS networks consist of public-supply wells and sample water from the part of the aquifer used for the public drinking-water supply (Burow and Belitz, 2014). Publicsupply wells are generally the deepest wells sampled. Wells in PAS networks are sampled once to assess groundwaterquality conditions in the study areas. The extents of PAS areas are defined by the U.S. Geological Survey (2003). Data from the following PAS networks are included in this report: the Basin and Range basin-fill aquifers (bnrfpas1; fig. 2), Coastal Lowlands aquifer system (clowpas1; fig. 3), glacial aquifer system (glacpas1; fig. 4), Northern Atlantic Coastal Plain aquifer system (nacppas1 and nacppas2; figs. 5-6), Southeastern Coastal Plain aquifer system (secppas1; fig. 7), and Valley and Ridge, and Piedmont and Blue Ridge carbonate-rock aquifers (vpdcpas1; fig. 8). 


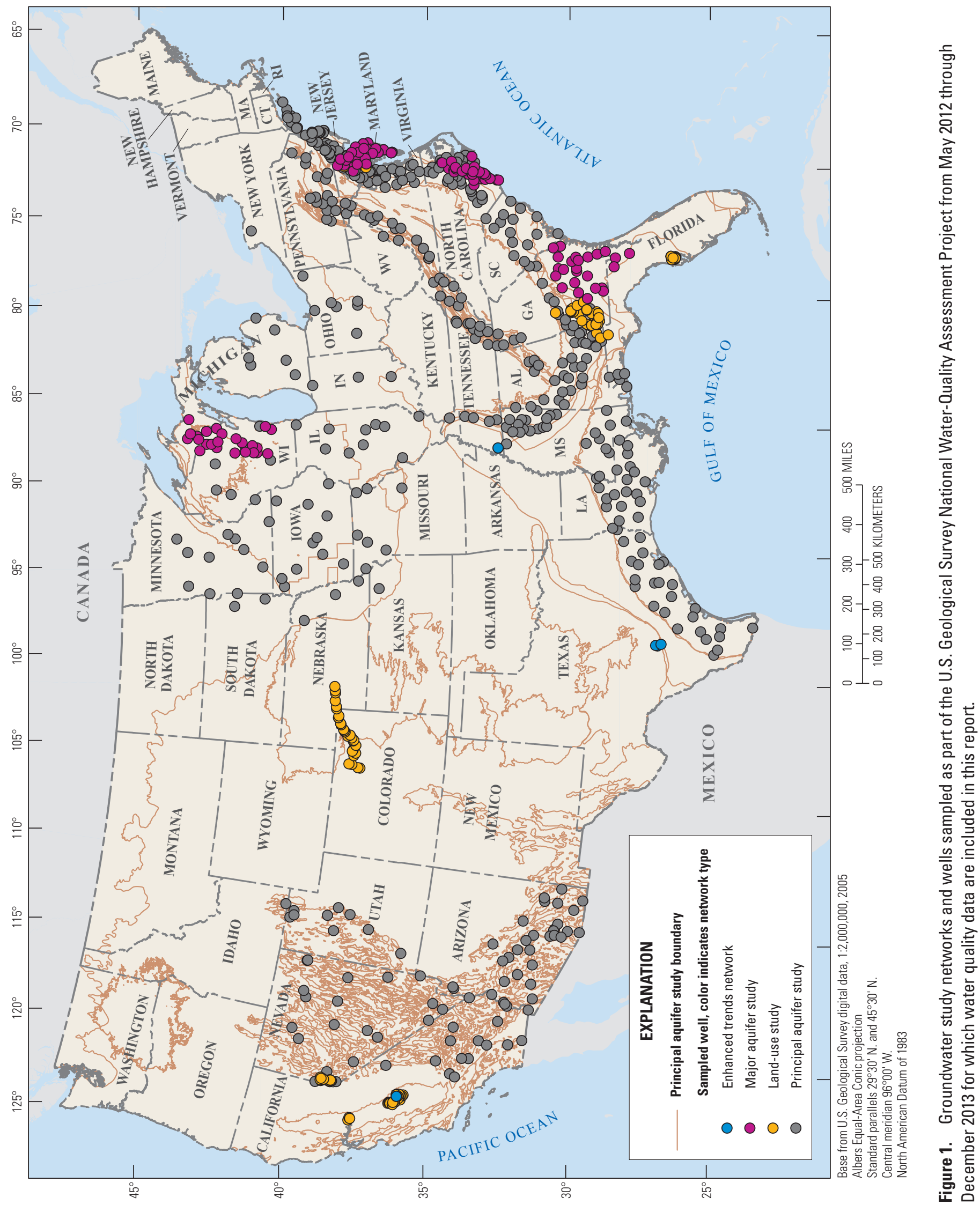




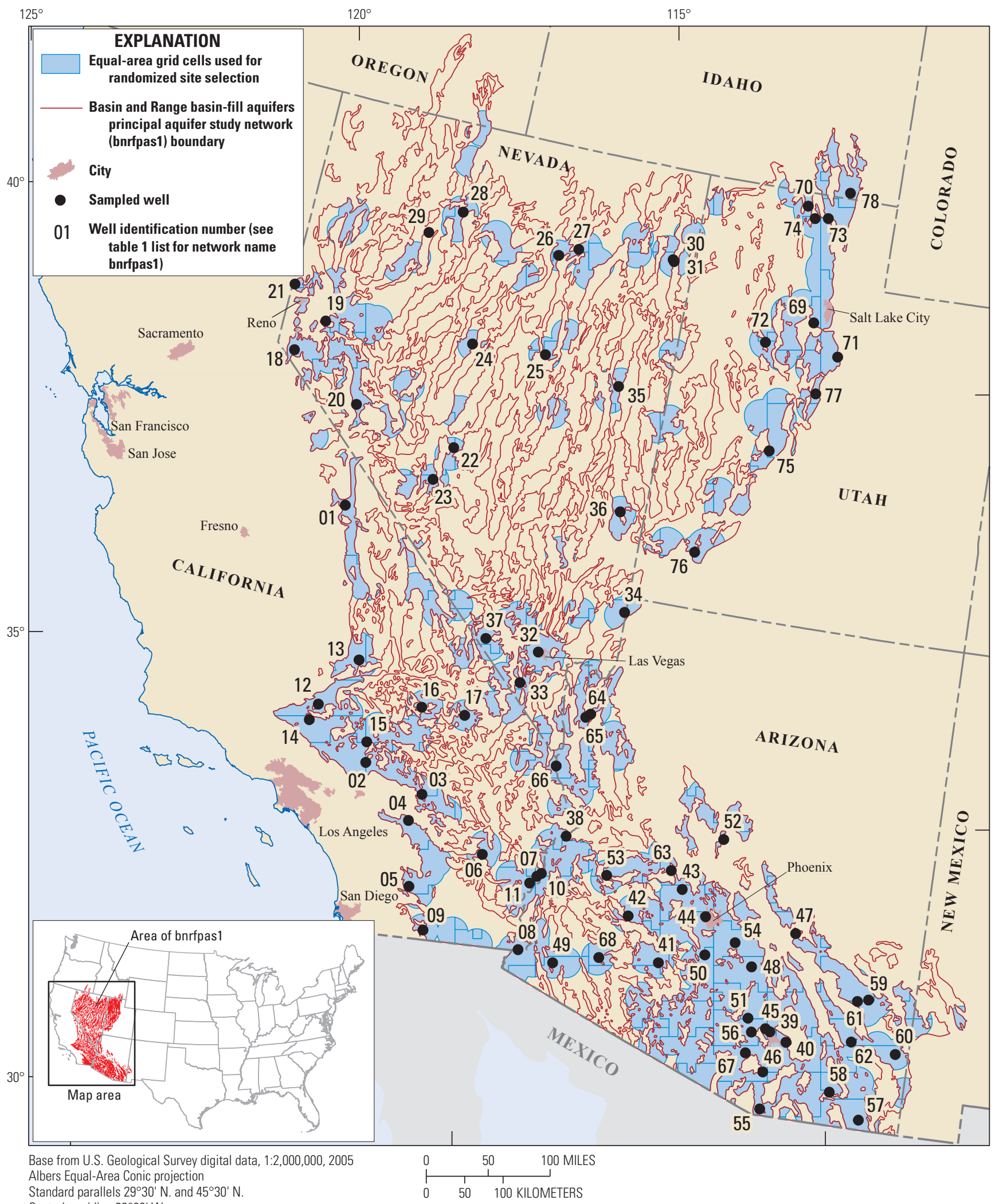

Standard parallels $29^{\circ} 30^{\prime} \mathrm{N}$ and $45^{\circ} 30^{\prime} \mathrm{N}$

Central meridian $96^{\circ} 00^{\prime} \mathrm{W}$.

Figure 2. Study area and wells sampled as part of the Basin and Range basin-fill aquifers principal aquifer study network (bnrfpas1) for the U.S. Geological Survey National Water-Quality Assessment Project, June through November 2013. 


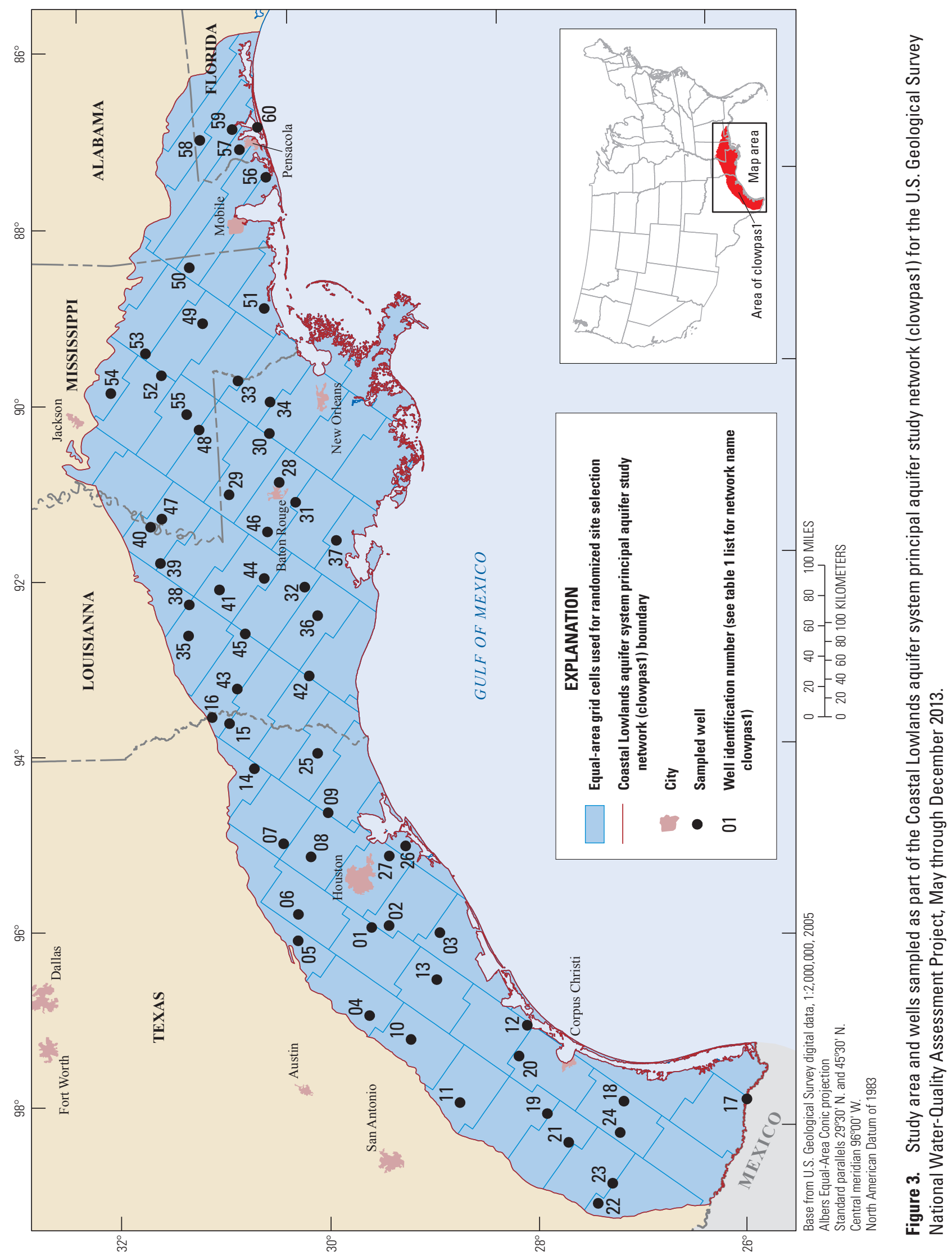




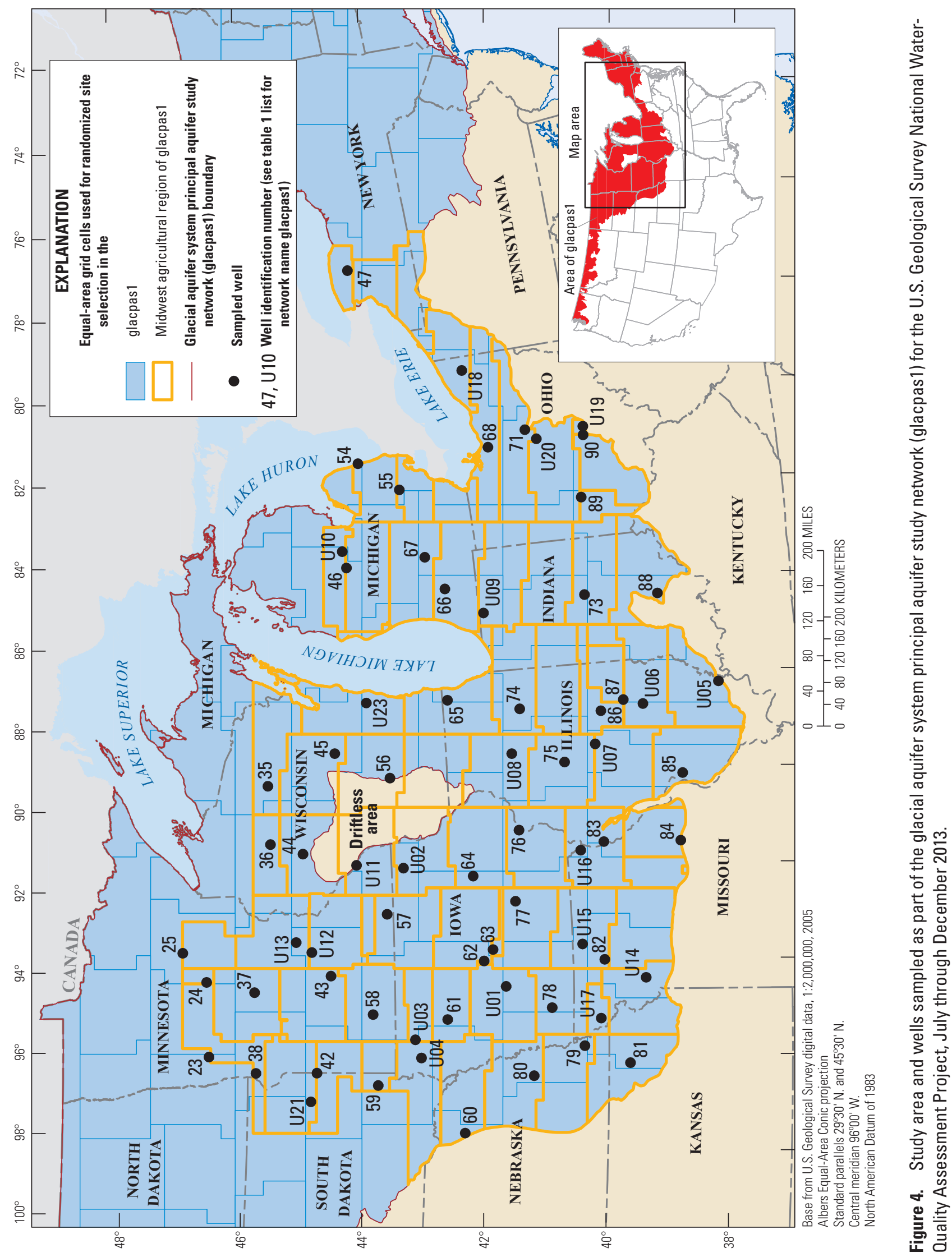




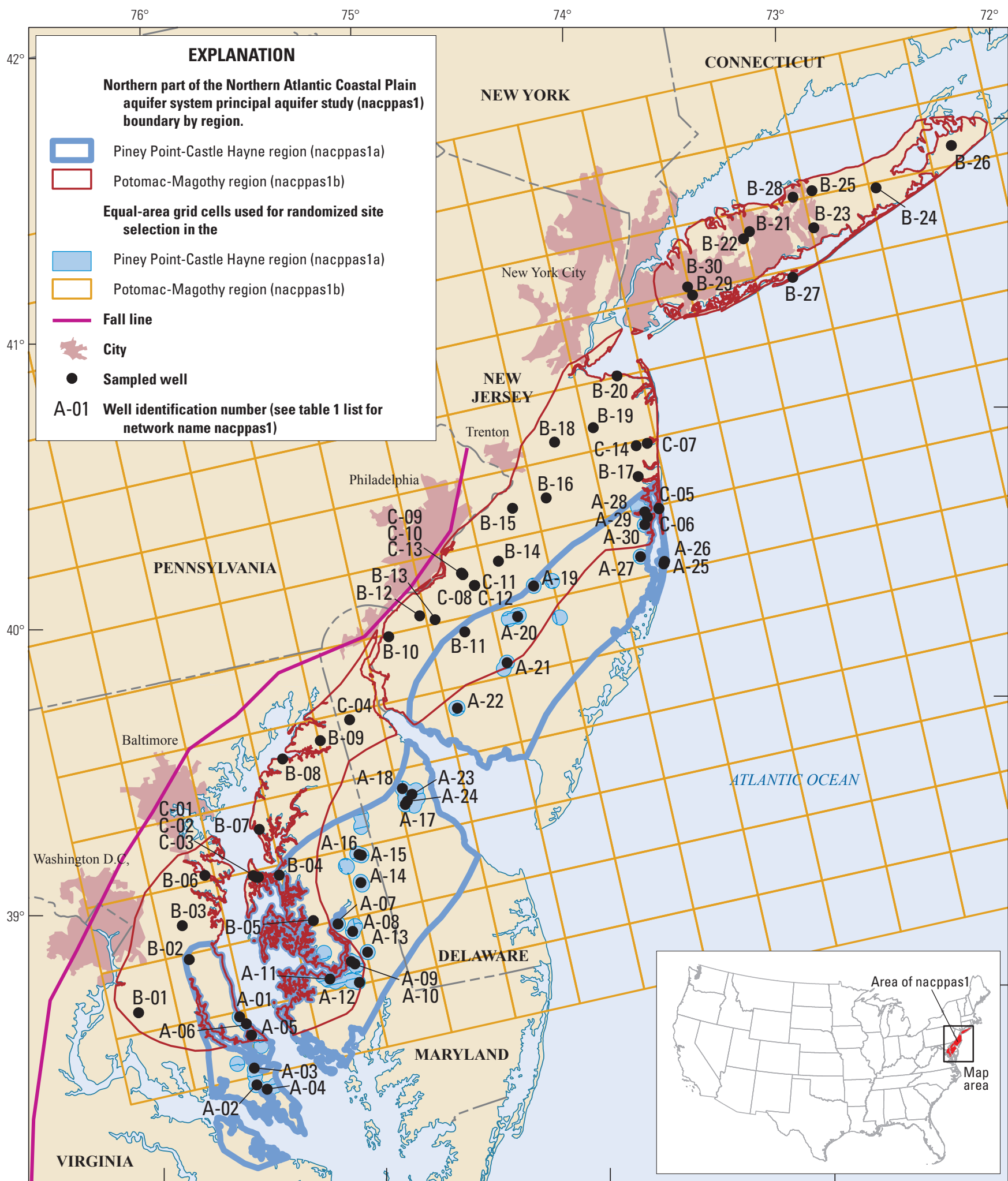

Base from U.S. Geological Survey digital data, 1:2,000,000, 2005 Albers Equal-Area Conic projection

Standard parallels $29^{\circ} 30^{\prime} \mathrm{N}$. and $45^{\circ} 30^{\prime} \mathrm{N}$.

Central meridian $96^{\circ} 00^{\prime} \mathrm{W}$.

North American Datum of 1983

Figure 5. Study area and wells sampled as part of the Northern Atlantic Coastal Plain aquifer system principal aquifer study network (nacppas1) in New Jersey, New York, Delaware, and Maryland for the U.S. Geological Survey National Water-Quality Assessment Project, May through October 2012. 


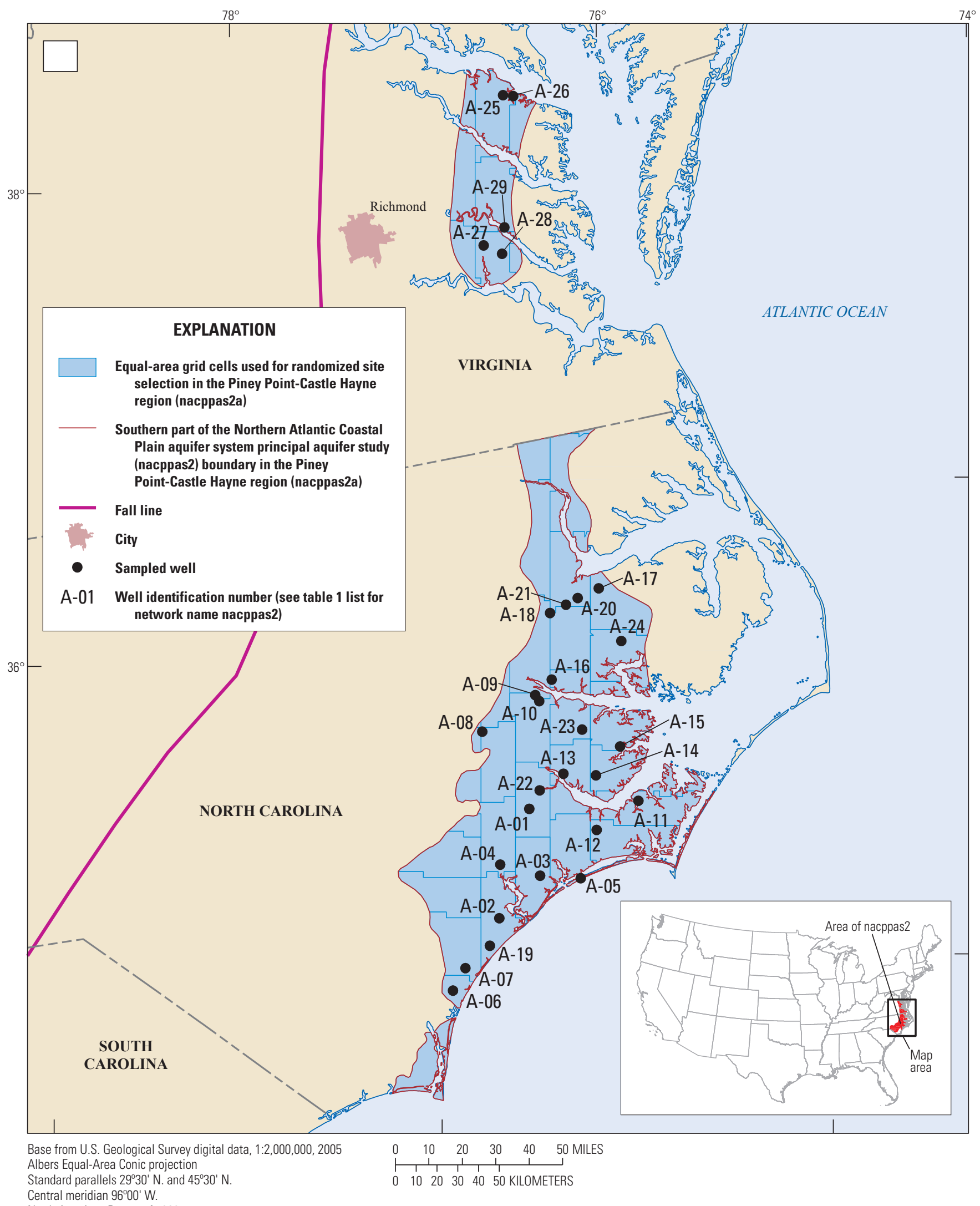

Central meridian $96^{\circ} 00^{\prime} \mathrm{W}$.

North American Datum of 1983

Figure 6. Study area and wells sampled as part of the Northern Atlantic Coastal Plain aquifer system principal aquifer study network (nacppas2) in Virginia and North Carolina for the U.S. Geological Survey National Water-Quality Assessment Project, July through November 2013. A. Study area and wells in the Piney Point-Castle Hayne aquifers. B. Study area and wells in the Potomac-Magothy aquifers. 


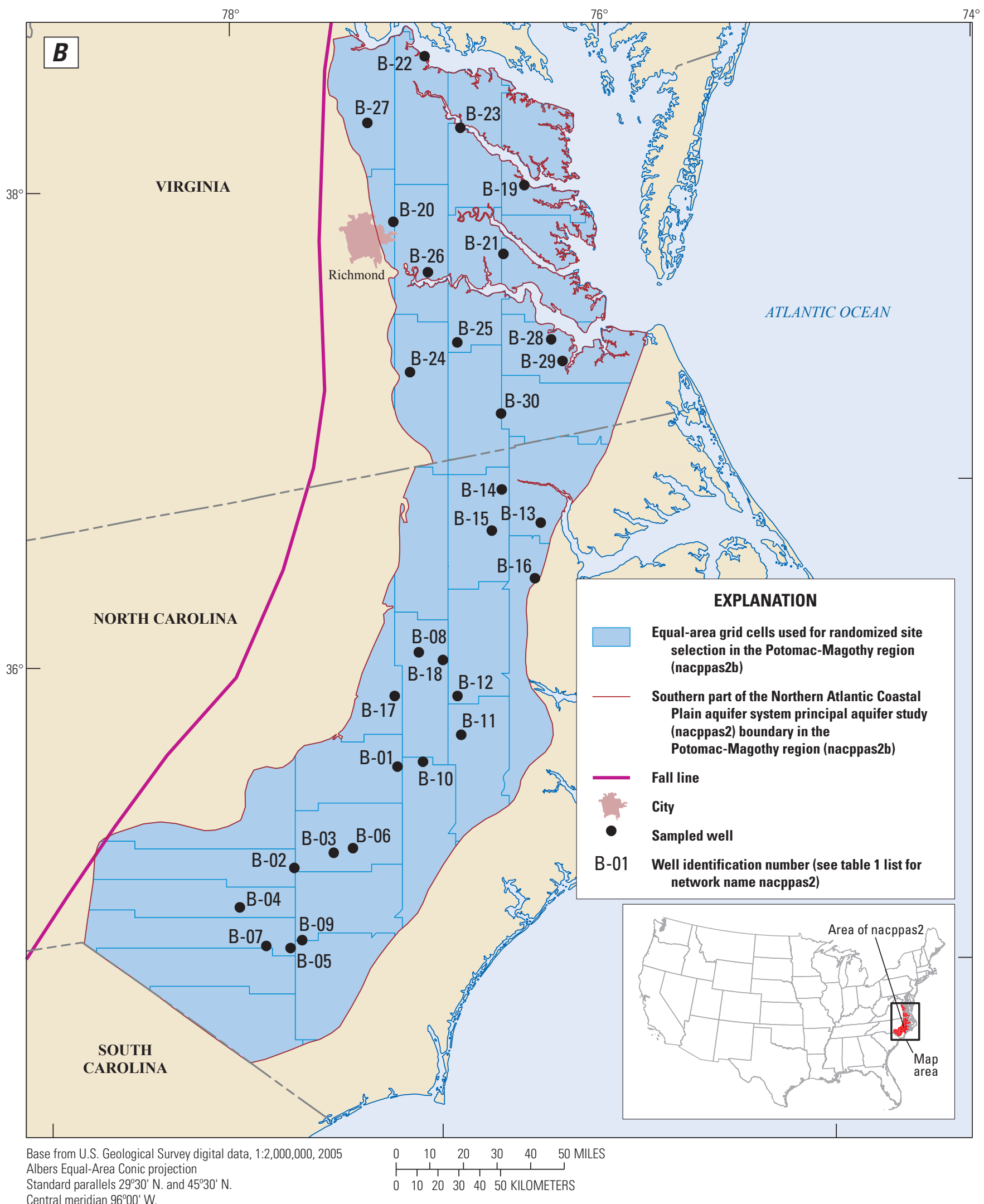

Central meridian $96^{\circ} 00^{\prime} \mathrm{W}$.

Figure 6. Study area and wells sampled as part of the Northern Atlantic Coastal Plain aquifer system principal aquifer study network (nacppas2) in Virginia and North Carolina for the U.S. Geological Survey National Water-Quality Assessment Project, July through November 2013. A. Study area and wells in the Piney Point-Castle Hayne aquifers. B. Study area and wells in the Potomac-Magothy aquifers.-Continued 


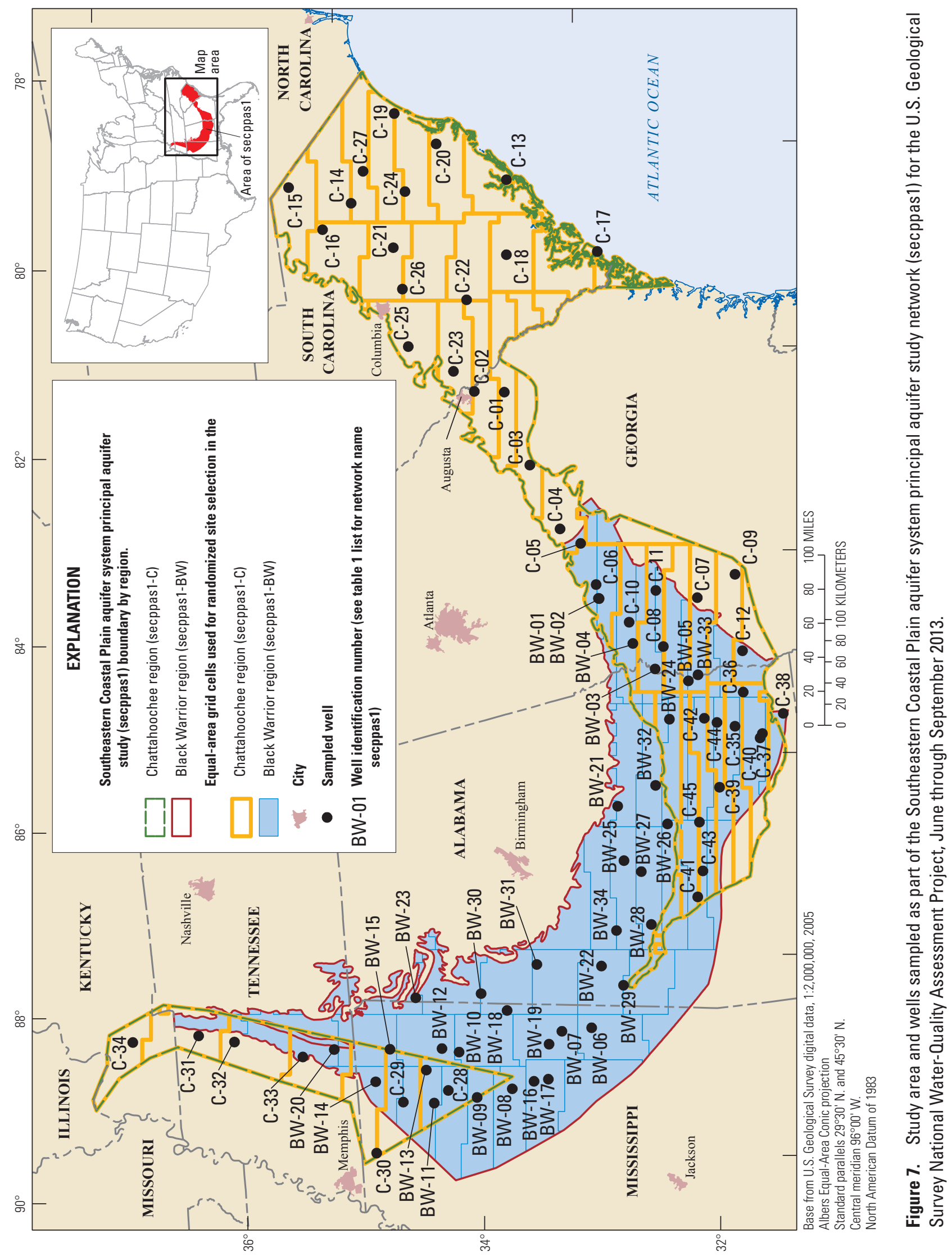




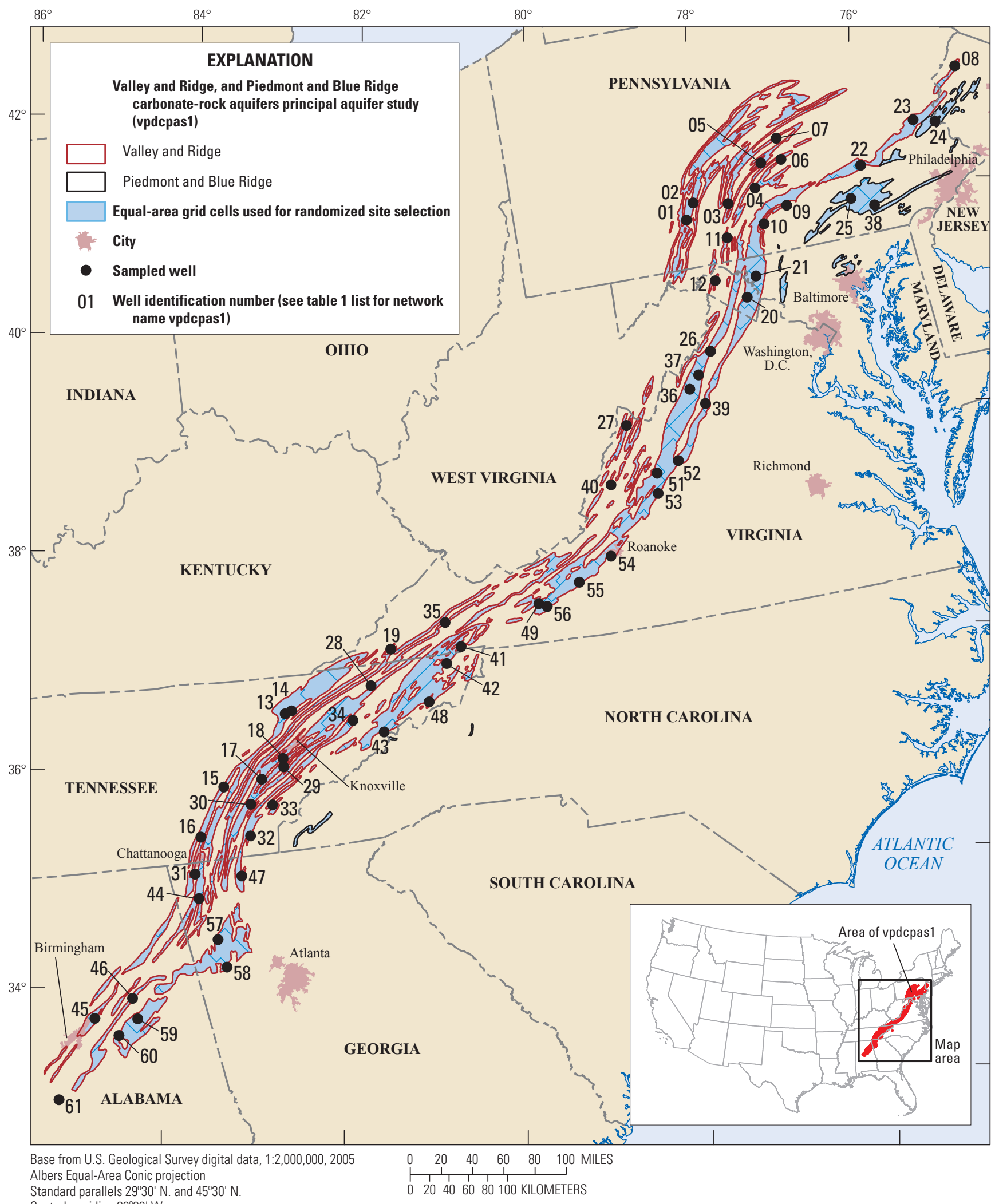

Central meridian $96^{\circ} 00^{\prime} \mathrm{W}$

North American Datum of 1983

Figure 8. Study area and wells sampled as part of the Valley and Ridge, and Piedmont and Blue Ridge carbonate-rock principal aquifer study network (vpdcpas1) for the U.S. Geological Survey National Water-Quality Assessment Project, July through October 2013. 


\section{Basin and Range Basin-Fill Aquifers Principal Aquifer Study Network (bnrfpas1)}

The Basin and Range basin-fill aquifers underlie an area of 148,000 square miles $\left(\mathrm{mi}^{2}\right)$, which includes about 12 million people in Nevada, California, Arizona, Utah, and adjacent states. The aquifers rank fourth in the Nation as a source of groundwater for public supply, with about 1 billion gallons per day pumped for this use in 2000 (Maupin and Barber, 2005; appendix 2). Land use overlying the Basin and Range basinfill aquifers consists primarily of natural land cover (92 percent), with relatively small areas of agricultural (4.2 percent) or urban (3.3 percent) land. The urban areas of Salt Lake City, Utah; Reno, Nevada; Las Vegas, Nev.; and Phoenix, Arizona, lie within the aquifers' boundaries.

The Basin and Range basin-fill aquifers are in about 330 sediment-filled basins that are separated by mountains of consolidated rock (Anning and Konieczki, 2005; Thiros and others, 2015). Sediments forming the basin fill are primarily unconsolidated to moderately consolidated deposits of gravel, sand, silt, and clay of Tertiary to Quaternary age. The basin deposits can range from about 1,000 to 5,000 feet (ft) in thickness in many basins, and can exceed $10,000 \mathrm{ft}$ in thickness in some basins in Utah and Arizona (Robson and Banta, 1995). Groundwater in the basin-fill aquifers is unconfined in most areas (Anning and Konieczki, 2005). The climate is generally arid, and almost all the precipitation in the basins and most of the precipitation in the mountains is lost to evapotranspiration (Robson and Banta, 1995). Recharge, from infiltration of mountain stream runoff and inflow from fractured bedrock, typically enters the aquifer along mountain fronts (Robson and Banta, 1995). Irrigation is a major source of recharge in some basins; and regional rivers, such as the Colorado River in California, also can be sources of recharge (Planert and Williams, 1995; Thiros and others, 2015). Although some groundwater in basin-fill aquifers discharges naturally to streams and springs, evapotranspiration is the largest natural component of discharge (Robson and Banta, 1995), particularly for basins that are topographically closed. In some basins, groundwater withdrawals for irrigation and (or) public supply have become the primary component of discharge and have altered directions of groundwater flow (Thiros and others, 2015).

The Basin and Range basin-fill aquifers PAS network (bnrfpas1; fig. 2) was designed to include 80 public-supply wells, selected using an equal-area grid of 80 cells. Parts of the region are sparsely populated, and public-supply wells are not evenly distributed across the bnrfpas 1 area; consequently, the equal-area grid was drawn within a 71,200- $\mathrm{mi}^{2}$ area that was defined by placing 12.4-mile buffers around the existing public-supply wells. The area of each cell was about $890 \mathrm{mi}^{2}$ (fig. 2). A total of 78 wells were sampled: 31 in Arizona, 17 in California, 1 in Idaho, 20 in Nevada, and 9 in Utah. The wells were typically 210 to $1,035 \mathrm{ft}$ deep (table 4-1; appendix 4) and open to the aquifer across long intervals (table 4-2; appendix 4). All wells were sampled between June and November of 2013.

\section{Coastal Lowlands Aquifer System Principal Aquifer Study Network (clowpas1)}

The Coastal Lowlands aquifer system underlies an area of 99,000 $\mathrm{mi}^{2}$ along the Gulf Coast, which includes about 15 million people in Texas, Louisiana, Mississippi, Alabama, and Florida. The aquifer system ranks fourth in the Nation as a source of groundwater used for public supply, tied with the Basin and Range basin-fill aquifers, with about 1 billion gallons per day pumped for this use in 2000 (Maupin and Barber, 2005; appendix 2). The Coastal Lowlands aquifer system ranks sixth as a source of private domestic supply Maupin and Arnold, 2010; appendix 2). Land use overlying the Coastal Lowlands aquifer system consists primarily of agricultural (24 percent) and natural (67 percent) land covers, with a relatively small percentage of urban ( 9 percent) land. The cities of Houston, Texas; New Orleans, Louisiana; Baton Rouge, Louisiana; and Mobile, Alabama, are included in the aquifer area.

Unconsolidated to partially consolidated sand, silt, and clay of Oligocene to Holocene age make up the Coastal Lowlands aquifer system. The sediments thicken and dip coastward, from a landward featheredge to as much as $14,000 \mathrm{ft}$ in southern Louisiana (Ryder, 1996; Renken, 1998). Recharge to the aquifer system occurs primarily as precipitation infiltrating topographically high areas and along the landward margin of the aquifer system. Once infiltrated, groundwater flows towards the coast and laterally towards the Mississippi River discharging to streams, wetlands, and the Gulf of Mexico (Renken, 1998). Previous studies have subdivided the Coastal Lowlands aquifer system into five permeable zones (Weiss, 1992). Because of the heterogeneous hydrogeologic composition and a lack of continuous confining units within the Coastal Lowlands aquifer system, however, it is difficult to distinguish between individual units (Renken, 1998). For the purpose of designing the Coastal Lowlands aquifer system PAS network (clowpas1; fig. 3) the aquifer system was considered one unit.

The clowpas 1 included 60 public-supply wells, selected using an equal-area grid of 60 cells, each about $1,650 \mathrm{mi}^{2}$ in area. Of the 60 wells sampled, 27 were located in Texas, 19 in Louisiana, 9 in Mississippi, 1 in Alabama, and 4 in Florida. The wells typically were between 250 to $1,104 \mathrm{ft}$ deep (table 4-1; appendix 4) and open to the aquifer across long intervals (table 4-2, ; appendix 4). The wells were sampled between May and December 2013.

\section{Glacial Aquifer System Principal Aquifer Study Network (glacpas1)}

The glacial aquifer system underlies nearly one million square miles of the northern contiguous United States, across parts of 25 states from Maine to Washington. The area underlain by this aquifer has a population of about 99 million people. The aquifer system provides more groundwater for public supply and private domestic supply than any other 
aquifer in the Nation, with about 2.6 billion gallons per day pumped for these uses in 2000 (Maupin and Barber, 2005; Maupin and Arnold, 2010; appendix 2). Land use in the area underlain by the glacial aquifer system is mostly agricultural in the central and west-central regions and mostly natural in the east and west. Large urban areas also are in area underlain by the glacial aquifer system, with nearly one-third (98 million people) of the United States population living in this area (Warner and Ayotte, 2015).

The glacial aquifer system consists of unconsolidated sediments left behind by the continental glaciers in the northern United States. The wide variety of glacial depositional processes and environments resulted in the accumulation of a heterogeneous mixture of sediments in a wide variety of hydrogeologic settings (Warner and Ayotte, 2015). Regionally, however, there are some general similarities in hydrogeologic setting and sediment type. In the east, glacial sediments fill crystalline bedrock valleys and cover broad low-lying areas with outwash deposits, typically ranging in thickness from less than 50 to $200 \mathrm{ft}$ (Olcott, 1995). Discontinuous layers of sand and gravel in these settings provide the most productive water supplies from the glacial aquifer system in the east. In the central and west-central regions, the glacial aquifer system consists of thick sequences of coarse- and fine-grained glacial sediments that fill and obscure previously formed bedrock valleys (as much as $400 \mathrm{ft}$ in thickness; Whitehead, 1996). Unsorted, fine-grained till sediments overlie the buried valleys and contain discontinuous layers of more permeable sediments. Northern areas in the central region also contain thick sequences of glacial-lake deposits. The west region of the glacial aquifer system consists mostly of coarse-grained sediments in valleys and in thick layers in flatter topography. Recharge to the glacial system is from precipitation, inflow from adjacent aquifers, or through confining units; discharge is typically to streams and other surface waters (Olcott, 1992, 1995).

The glacial aquifer system PAS network (glacpas1) extends across the glaciated areas of the lower 48 states and includes 115 public supply wells, in total, which were sampled during 2013 (69 wells) and 2014 (46 wells). Three-fourths of the wells are spatially distributed throughout the aquifer area. These wells were selected using an equal-area grid that divided the glacial region into 90 cells, each about $8,000 \mathrm{mi}^{2}$ in area. Data from 47 wells selected from the 90 -cell grid are included in this report; 43 additional wells were sampled in 2014, and data from those samples will be included in a future report. An additional 25 wells were spatially distributed in the Midwestern agricultural region (MAR) of the glacial aquifer using a second equal-area grid overlying the original 90-cell grid. The second grid had 60 cells, each about $6,000 \mathrm{mi}^{2}$. In the area where the two equal-area grids overlapped, a well was selected for sampling if a cell from the second grid did not already contain a well selected from the 90-cell grid (fig. 4). The result of the overlap was a grid with 72 cells (average size $5,000 \mathrm{mi}^{2}$ ) and a denser distribution of wells in the Midwestern agricultural region than in the rest of the aquifer area (fig. 4). Of the 25 wells, 22 are shown in the tables and figure 4 with a NAWQA Project ID number that has a "U" before the sequence number; 3 of the 25 wells were sampled in 2014, and data from those three will be included in a future report. The MAR was defined through analysis of groundwater quality data as one of five areas with distinct water-quality characteristics in the glacial aquifer system (Arnold and others, 2008). The MAR was selected for additional assessment of the quality of public drinking-water supplies because it is an area with intensive agrichemical inputs and relatively high water use for public supply as compared with other parts of the glacial aquifer system (Warner and Ayotte, 2015). Wells in the glacpas1 were sampled in 2013 and 2014; wells sampled in 2013, for which data are given in this report, included wells in the MAR ( 69 wells). The wells for which data are included in this report were typically 44 to $223 \mathrm{ft}$ deep (table 4-1; appendix 4) and open to the aquifer across lengths of 10 to 40 $\mathrm{ft}$ (table 4-2; appendix 4). The distribution of sampled wells among states is given in table 1 .

\section{Northern Atlantic Coastal Plain Aquifer System Principal Aquifer Study Networks (nacppas1 and nacppas2)}

The Northern Atlantic Coastal Plain aquifer system underlies an area of about $44,000 \mathrm{mi}^{2}$, which includes about 22 million people in parts of New York, New Jersey, Delaware, Maryland, Virginia, and North Carolina. The aquifer system ranks seventh in the Nation as a source of groundwater for public supply and fourth for domestic supply, supplying about 930 million gallons per day pumped for these uses in 2000 (Maupin and Barber, 2005; Maupin and Arnold, 2010; appendix 2). Land use overlying the aquifer system is about 62 percent natural, 24 percent agricultural, and 14 percent urban. The cities of New York, New York; Trenton, New Jersey; Philadelphia, Pennsylvania; Baltimore, Maryland; Washington, D.C.; and Richmond, Virginia, are along the western edge of the aquifer system - this boundary, called the Fall Line, is where upstream navigation along major rivers is limited and separates the rolling hills and ridges of the Piedmont to the west and the nearly flat-lying coastal plain to the east (Denver and others, 2014).

The Northern Atlantic Coastal Plain aquifer system consists of unconsolidated to partly consolidated sediments that range in age from Early Cretaceous to Holocene (Trapp and Horn, 1997; Masterson and others, 2013; Denver and others, 2014). The sedimentary layers thicken and deepen seaward from the Fall Line, where they pinch out against crystalline bedrock, to the Atlantic Coast, where sediments reach a maximum thickness of about 10,000 ft in North Carolina. A series of clay and silt confining layers separate 10 regional aquifers that are used for water supply (Trapp and Horn, 1997; Masterson and others, 2013). Recharge enters the aquifer mostly from the outcrop areas in the landward part of the aquifer system, but some recharge comes from downward leakage 
through confining units. Groundwater discharge is to streams, wetlands, and coastal waters.

Regional stacked aquifers, grouped as the Piney PointCastle Hayne aquifers (overlying) and the Potomac-Magothy aquifers (underlying), were selected for study based on their importance as sources of public supply. The Piney Point aquifer is a confined sand aquifer in Maryland, Delaware, New Jersey, and Virginia (DePaul and others, 2008); the Castle Hayne aquifer, composed of limestone, sandy marl, and fine to coarse limey sand, is its equivalent in North Carolina and also is included for study (Trapp and Horn, 1997). The Castle Hayne aquifer is considered to be a separate principal aquifer (U.S. Geological Survey, 2003), but because it is within and hydraulically connected to the Northern Atlantic Coastal Plain aquifer system, the Castle Hayne was included as part of the larger coastal plain system. The Piney Point aquifer was selected for sampling because, although it has relatively low groundwater withdrawals compared to other aquifers in the northern states, withdrawals from the Castle Hayne aquifer in North Carolina are the largest of any aquifer in that state (DePaul and others, 2008). The Potomac-Magothy aquifers, as used in this report, are a group of three regional aquifers: the Magothy, Potomac-Patapsco, and Potomac-Patuxent aquifers (Masterson and others, 2015). The Magothy aquifer is used most heavily for water supply in New York and New Jersey, and the Potomac aquifers are used most heavily for water supply in Maryland and Virginia.

Two study networks were defined in the Northern Atlantic Coastal Plain aquifer system: the northern part of the North Atlantic Coastal Plain aquifer system PAS network (nacppas1, fig. 5) in New Jersey, New York, Delaware, and Maryland; and the southern part of the North Atlantic Coastal Plain aquifer system PAS network (nacppas2; fig. 6) in Virginia and North Carolina. Both northern and southern networks were designed to include 60 public supply wells, 30 wells from the Piney Point or Castle Hayne regional aquifers (nacppas1a, fig. 5; and nacppas2a. fig. $6 A$ ) and 30 wells from the Potomac-Magothy regional aquifers (nacppas $1 \mathrm{~b}$, fig. 5 ; and nacppas $2 \mathrm{~b}$, fig. $6 B$ ). Wells were selected using 30 -cell, equal-area grids. Publicsupply wells were unevenly distributed across the area of nacppas1, so the following methods were used to minimize the number of grid cells that contained no or very few wells. For the nacppas 1 a network (fig. 5) in the Piney Point aquifers, 1.9-mi buffers were placed around all known public-supply wells, and the equal-area grid was drawn within the resulting, aggregated buffered area. For the nacppas $1 b$ network in the Potomac-Magothy aquifers, an iterating method, in which a grid of square cells is overlain on the study region repetitively, was used to select the 30 wells for sampling (Scott, 1990).

The distribution of sampled wells among states, regional aquifers, and networks is given in table 1. The nacppas1 included 14 wells that were added to support the needs of the USGS Groundwater Resources Program (nacppas1c; fig. 5), in addition to the 60 wells that were selected using the stratified random design and equal area grids. These 14 wells were completed in the Northern Atlantic Coastal Plain aquifer system but not necessarily in the Piney Point-Castle Hayne or Potomac-Magothy aquifers. The nacppas 2 included 59 wells rather than the 60 for which the network was designed. The nacppas2 has four wells that also are in another network (albesus7). Data from all wells in the nacppas1 and nacppas2 are included in this report. Most wells in the nacppas 1 and nacppas 2 were between about 200 and $700 \mathrm{ft}$ deep (table 4-1; appendix 4), with a wide range of open interval lengths (table 4-2; appendix 4). Wells in nacppas1 were sampled May to October 2012, and wells in nacppas2 were sampled July to November 2013.

\section{Southeastern Coastal Plain Aquifer System Principal Aquifer Study Network (secppas1)}

The Southeastern Coastal Plain aquifer system underlies an area of more than $120,000 \mathrm{mi}^{2}$, which includes about 6 million people in Kentucky, Tennessee, Mississippi, Alabama, Georgia, Florida, and South Carolina. The aquifer system ranks fifteenth in the Nation as a source of groundwater for public supply, with about 340 million gallons per day pumped for this use in 2000 (Maupin and Barber, 2005; appendix 2). Land use in the area overlying the Southeastern Coastal Plain aquifer system is primarily agricultural (19 percent) and natural land cover (74 percent), with a relatively smaller percentage of urban (7 percent) land.

The Southeastern Coastal Plain aquifer system is composed of sand, silt, clay, and other sediments of Cretaceous and Tertiary age. The sediments generally thicken and dip towards the Atlantic and Gulf coasts, where they are several thousand feet thick and are buried beneath other aquifers (Renken, 1984; Miller, 1990). Recharge is primarily from precipitation infiltrating at the outcrop areas of aquifer system, and most groundwater discharge is to streams or to evapotranspiration (Miller, 1990). Four regional aquifers, separated by four regional confining units of silt and clay, make up the aquifer system. The two lower units, the Chattahoochee River aquifer and Black Warrior River aquifer, are present throughout most of the aquifer system and contribute most water for public supply from the Southeastern Coastal Plain aquifer system. These two aquifers were selected for sampling to characterize groundwater used for public supply in the Southeastern Coastal Plain aquifer system. Both aquifers consist primarily of sand with interbedded clay lenses (Miller, 1990).

The Southeastern Coastal Plain aquifer system PAS network (secppas1; fig. 7) was designed to include 80 publicsupply wells, with 40 wells in each regional aquifer. Wells were selected using an equal-area grid for the Chattahoochee aquifer that extended across $47,000 \mathrm{mi}^{2}$ and an equal-area grid for the Black Warrior aquifer that extended across 42,000 $\mathrm{mi}^{2}$. Not enough wells could be located in the regional aquifers as designed, however. The final distribution of wells was 45 wells in the Chattahoochee River aquifer and 34 wells in the Black 
Warrior aquifer, for a total of 79 wells in the secppas1. The distribution of wells among states is given in table 1. Wells in the secppas 1 were typically about 260 to $1,760 \mathrm{ft}$ deep (table 4-1; appendix 4) and had a wide range of open interval lengths (table 4-2; appendix 4). All wells in the study network were sampled between May and December 2013.

\section{Valley and Ridge, and Piedmont and Blue Ridge Carbonate-Rock Aquifers Principal Aquifer Study Network (vpdcpas1)}

The Valley and Ridge, and Piedmont and Blue Ridge carbonate-rock aquifers underlie an area of about 17,000 $\mathrm{mi}^{2}$, which includes about 5 million people in New Jersey, Pennsylvania, Maryland, West Virginia, Virginia, Tennessee, North Carolina, Georgia, and Alabama. The carbonate-rock aquifers are a significant source of water for public and domestic supply locally; and, together with the other rock types of the Valley and Ridge and the Piedmont and Blue Ridge aquifers, rank second in the Nation as a source of groundwater for private domestic supply (Maupin and Arnold, 2010; appendix 2). Large percentages of the land overlying the Valley and Ridge, and Piedmont and Blue Ridge carbonate-rock aquifers are agricultural (35 percent) and urban (17 percent).

The Valley and Ridge, and Piedmont and Blue Ridge carbonate-rock aquifers are similar in rock type and hydrogeologic characteristics. The aquifers consist mostly of Paleozoic and Precambrian limestone and dolomite (Trapp and Horn, 1997) and are adjacent or interspersed with crystalline- or siliciclastic- rock aquifers. Because the carbonate rocks are more soluble than the noncarbonate rocks that are nearby, the carbonate-rock aquifers are typically in valleys. Most recharge to these carbonate-rock aquifers is from local precipitation in the overlying valleys, but recharge also enters the aquifers from the adjacent crystalline- or siliciclastic-rock ridges. The carbonate-rock aquifers are productive aquifers because the dissolution of the carbonate rocks forms secondary solution channels and enhances the flow of water. Individual well yields are high in the carbonate-rock aquifers relative to well yields in other bedrock types in the region. Another result of the high solubility of carbonate rocks is that sinkholes form easily, and surface runoff can enter directly into open sinkholes bypassing filtration through soils or overburden. The carbonate-rock aquifers are unconfined to confined, but confinement is typically local and because of the presence of a thick, impervious layer of overburden or a low permeability rock type such as shale.

The Valley and Ridge, and Piedmont and Blue Ridge carbonate-rock aquifers PAS network (vpdcpas1; fig. 8) was designed to include 60 public-supply wells. Wells were selected using an equal-area grid (cell size about $300 \mathrm{mi}^{2}$ ). Public-supply wells in the Valley and Ridge carbonate-rock aquifers could only be located in 59 of the 60 cells; however, one well selected in the secppas 1 in Alabama was inadvertently located in the Valley and Ridge carbonate-rock aquifers and so was added to the vpdcpas1. Data for all 60 wells in the vpdcpas 1 are included in this report; the distribution of wells among states is provided in table 1 . The wells were typically 165 to $550 \mathrm{ft}$ deep (table 4-1; appendix 4) and had a wide range of open interval lengths (table 4-2; appendix 4). All wells were sampled between July and October 2013.

\section{Decadal Trends Networks - Land Use Study Networks}

The LUS networks are designed to facilitate analysis of land-use effects on shallow groundwater quality. Wells in LUS networks are sampled once per decade to assess temporal trends in water quality. Wells in LUS networks typically are shallow and screened near the water table to allow sampling of recently recharged groundwater that may exhibit chemical characteristics indicative of the surrounding land use. The LUS areas are determined by the areal extents of the primary aquifer and a targeted overlying land use (Lapham and others, 1995). Data from the following LUS networks are included in this report: the Apalachicola-Chattahoochee-Flint River agricultural LUS network (acfbluscr3; fig. 9); Delmarva Peninsula agricultural LUS network (dlmvluscr1; fig. 10); Georgia-Florida urban LUS network near Tampa, Florida (gafllusrc1; fig. 11); Nevada Basin and Range urban LUS network near Reno and Eagle Valley, Nevada (nvbrlusrc1; fig. 12); San Joaquin Valley orchard agricultural LUS network (sanjlusor1a; fig. 13); and South Platte agricultural LUS network (spltluscr1; fig. 14). 


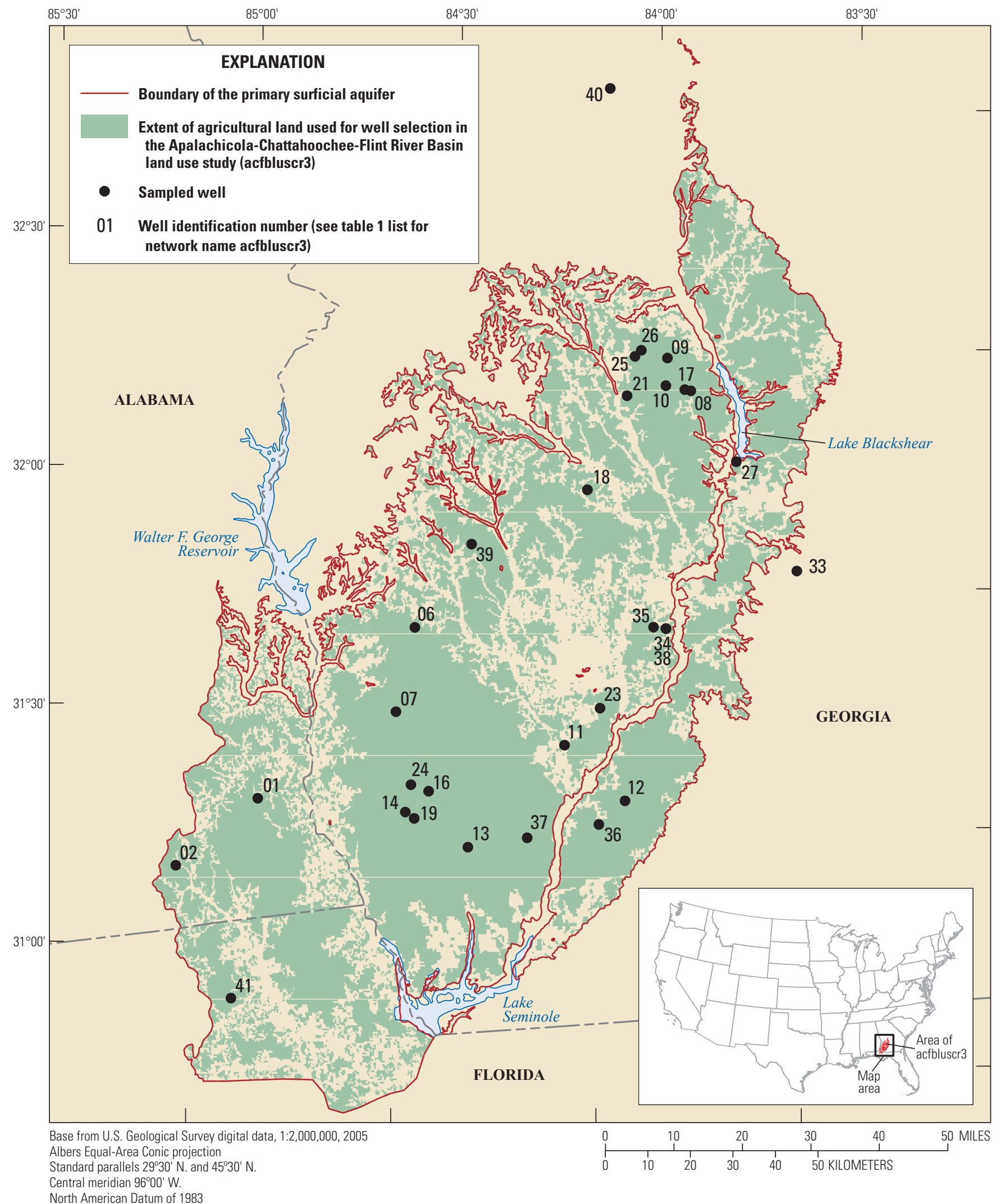

Figure 9. Study area and wells sampled as part of the Apalachicola-Chattahoochee-Flint River Basin agricultural land use study network (acfbluscr3) for the U.S. Geological Survey National Water-Quality Assessment Project, August through September 2013. 


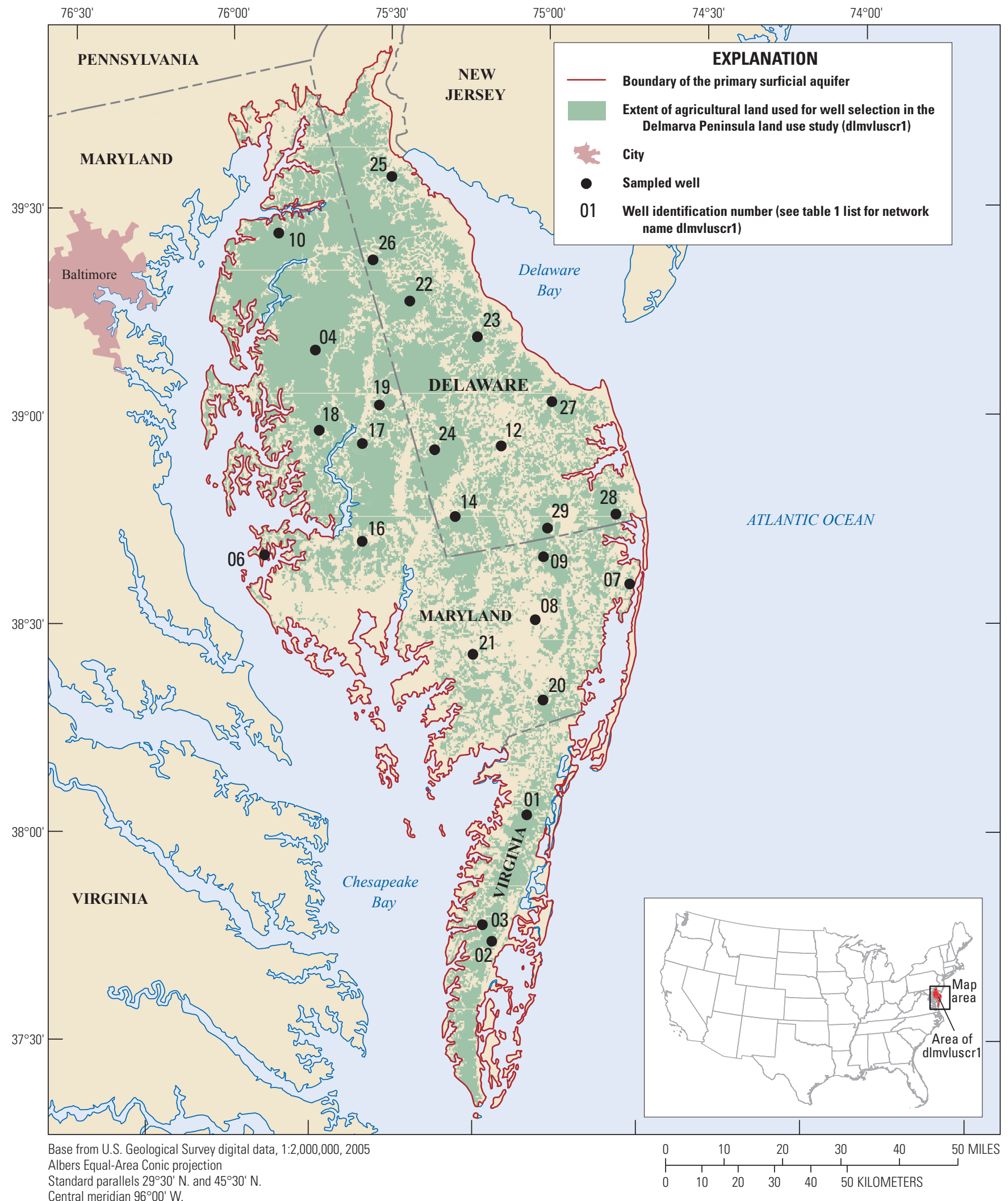

Central meridian $96^{\circ} 00^{\prime} \mathrm{W}$.

Figure 10. Study area and wells sampled as part of the Delmarva Peninsula agricultural land use study network (dlmvluscr1) for the U.S. Geological Survey National Water-Quality Assessment Project, July through September 2012. 


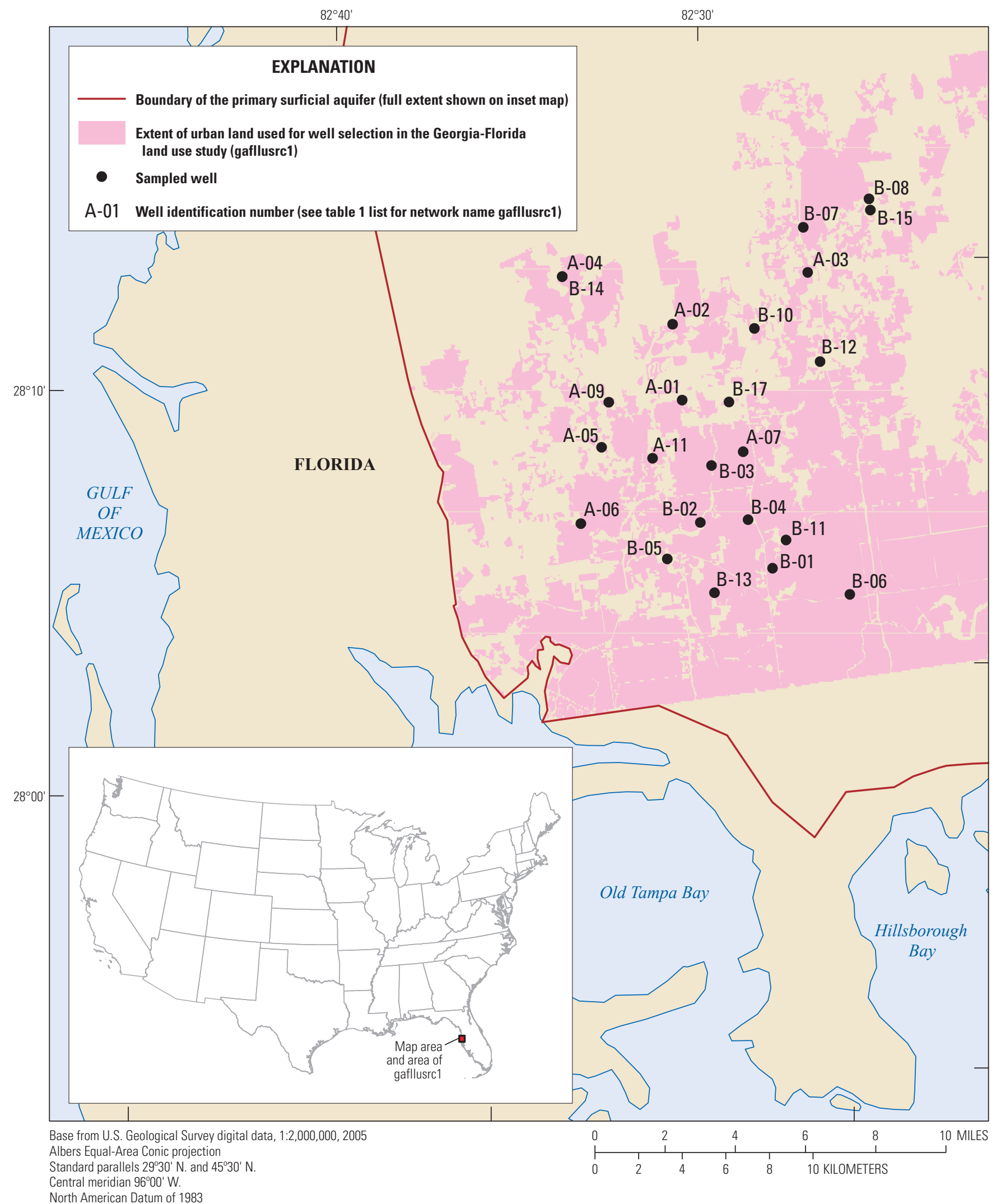

Figure 11. Study area and wells sampled as part of the Georgia-Florida urban land-use study network (gafllusrc1) near Tampa, Florida, for the U.S. Geological Survey National Water-Quality Assessment Project, July through November 2012. 


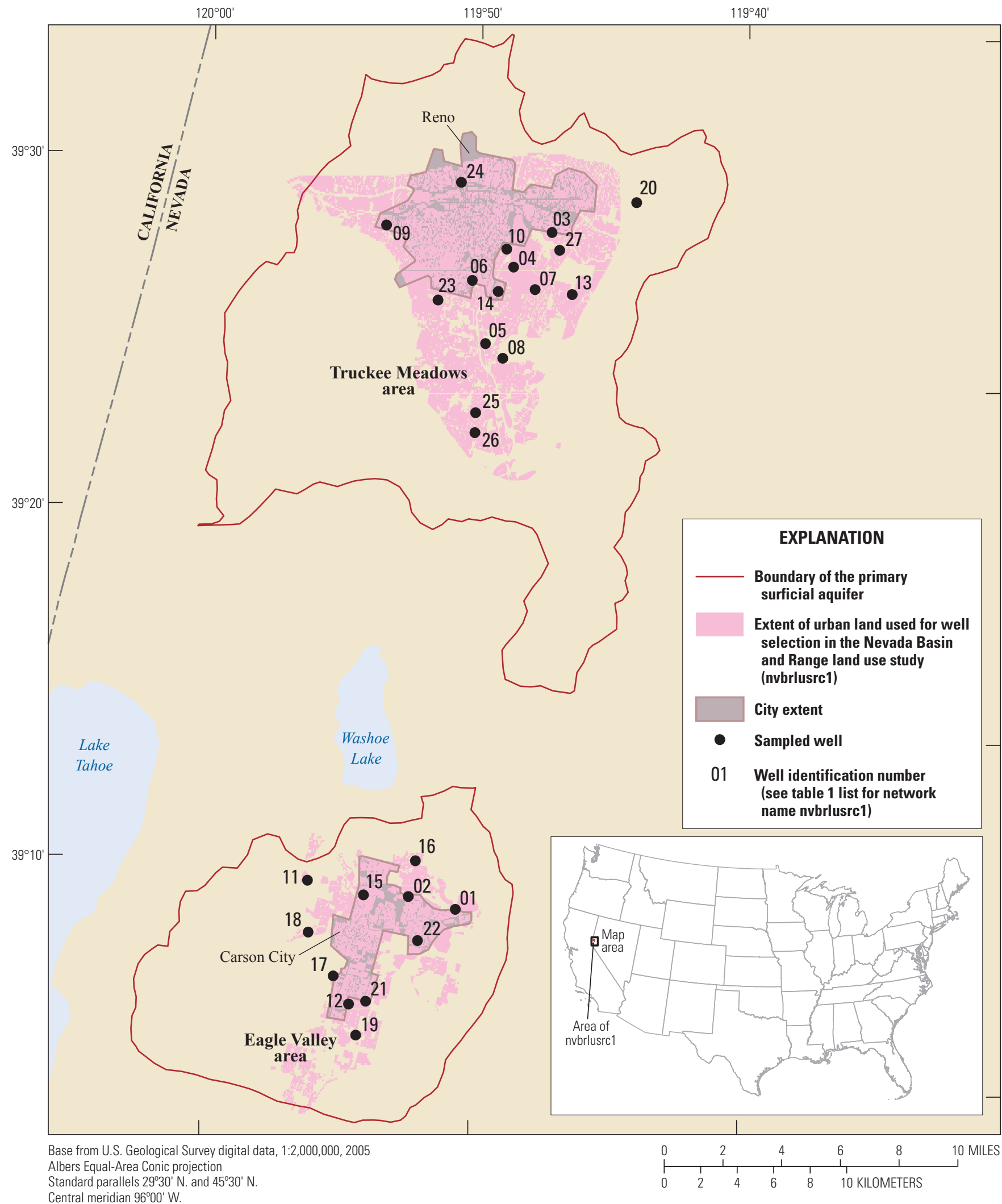

Central meridian $96^{\circ} 00^{\prime} \mathrm{W}$

North American Datum of 1983

Figure 12. Study area and wells sampled as part of the Nevada Basin and Range urban land use study network (nvbrlusrc1) near Reno and Carson City, Nevada, for the U.S. Geological Survey National Water-Quality Assessment Project, April through June 2013. 


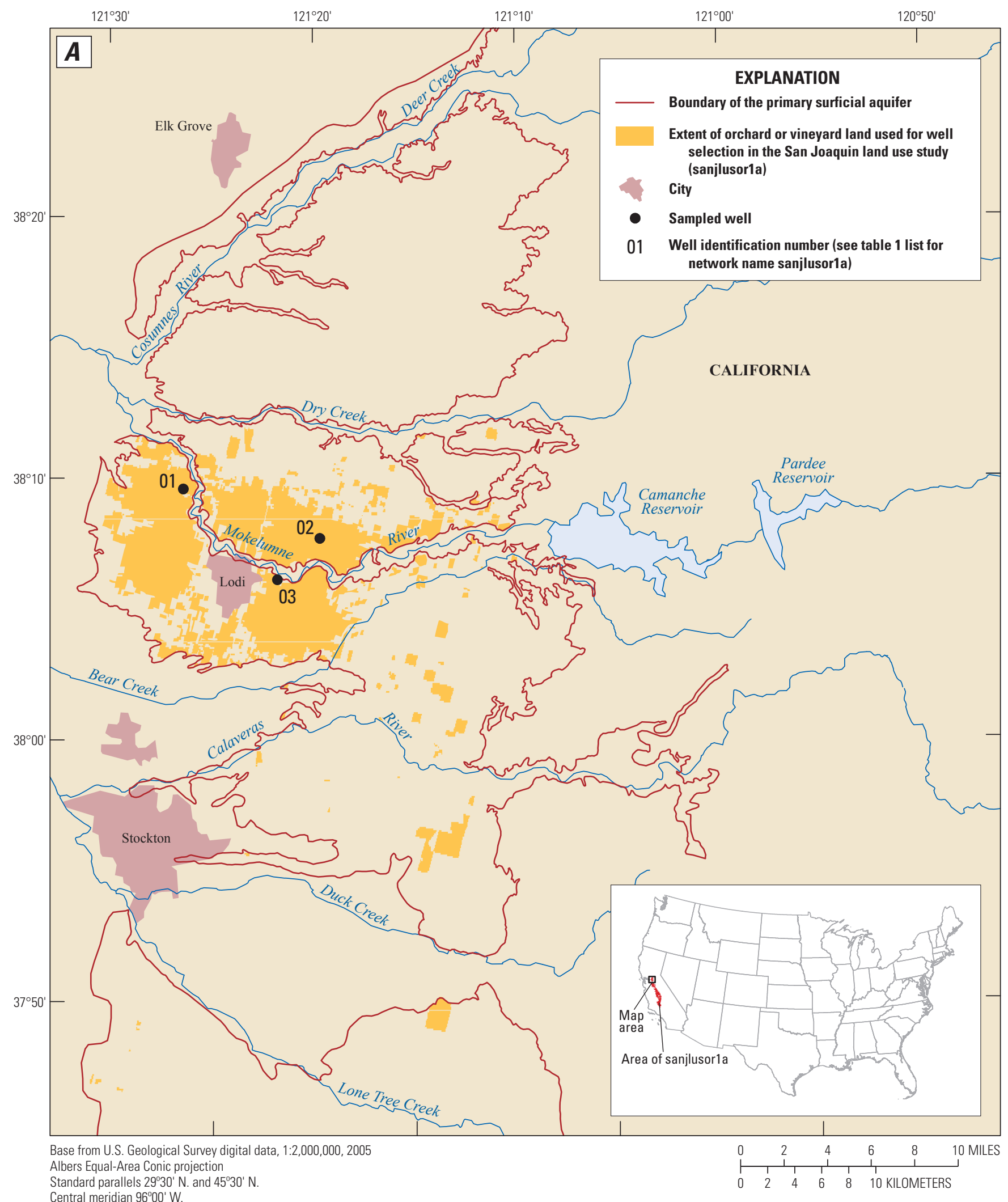

Central meridian $96^{\circ} 00^{\prime} \mathrm{W}$.

North American Datum of 1983

Figure 13. Study area and wells sampled as part of the San Joaquin agricultural land use study network (sanjlusor1a) for the U.S. Geological Survey National Water-Quality Assessment Project, July 2013. A, Northern part of the study area, near Stockton, California. $B$, Southern part of the study area near Fresno, California. 


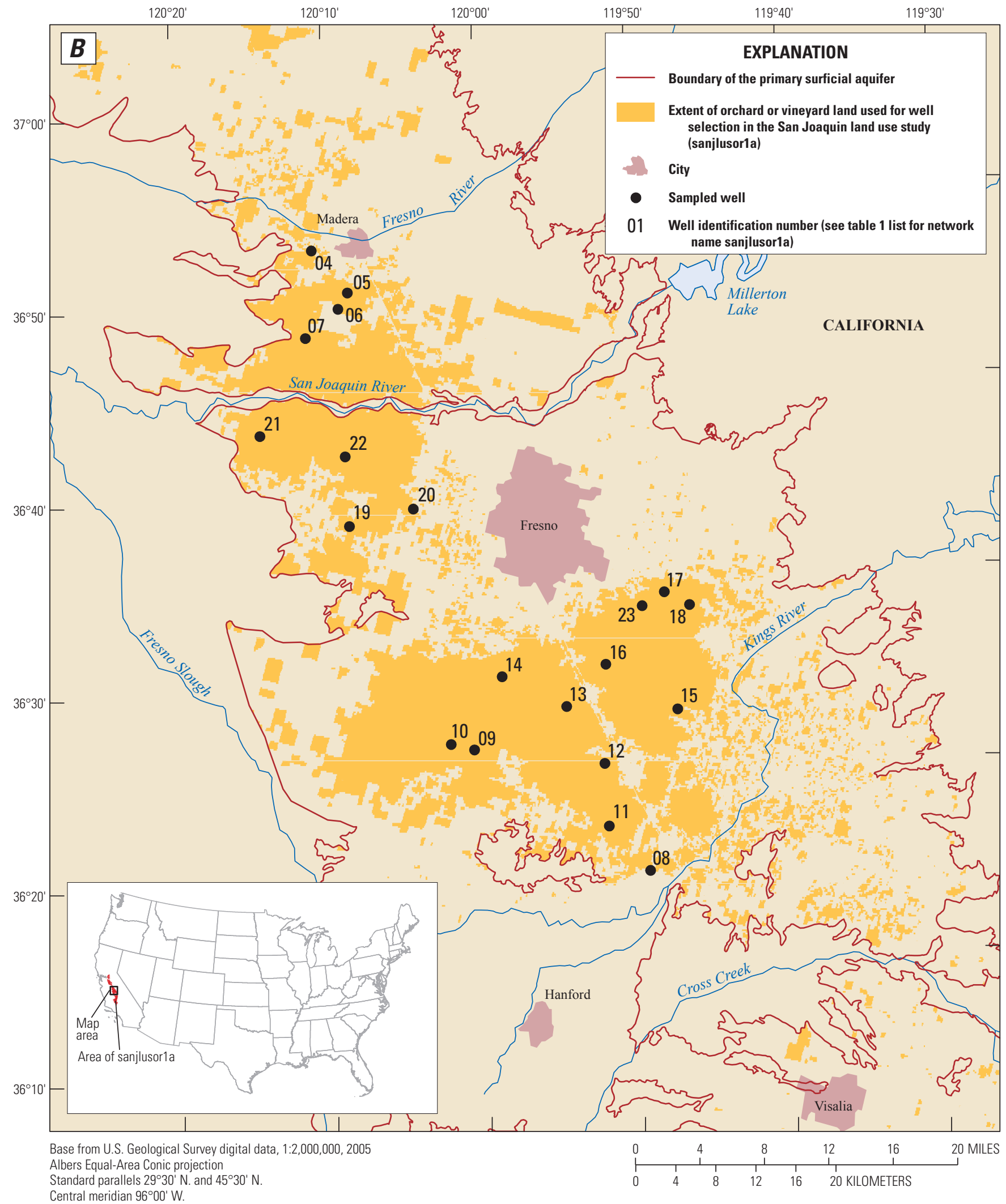

North American Datum of 1983

Figure 13. Study area and wells sampled as part of the San Joaquin agricultural land use study network (sanjlusor1a) for the U.S.

Geological Survey National Water-Quality Assessment Project, July 2013. A, Northern part of the study area, near Stockton, California. $B$, Southern part of the study area near Fresno, California.-Continued 


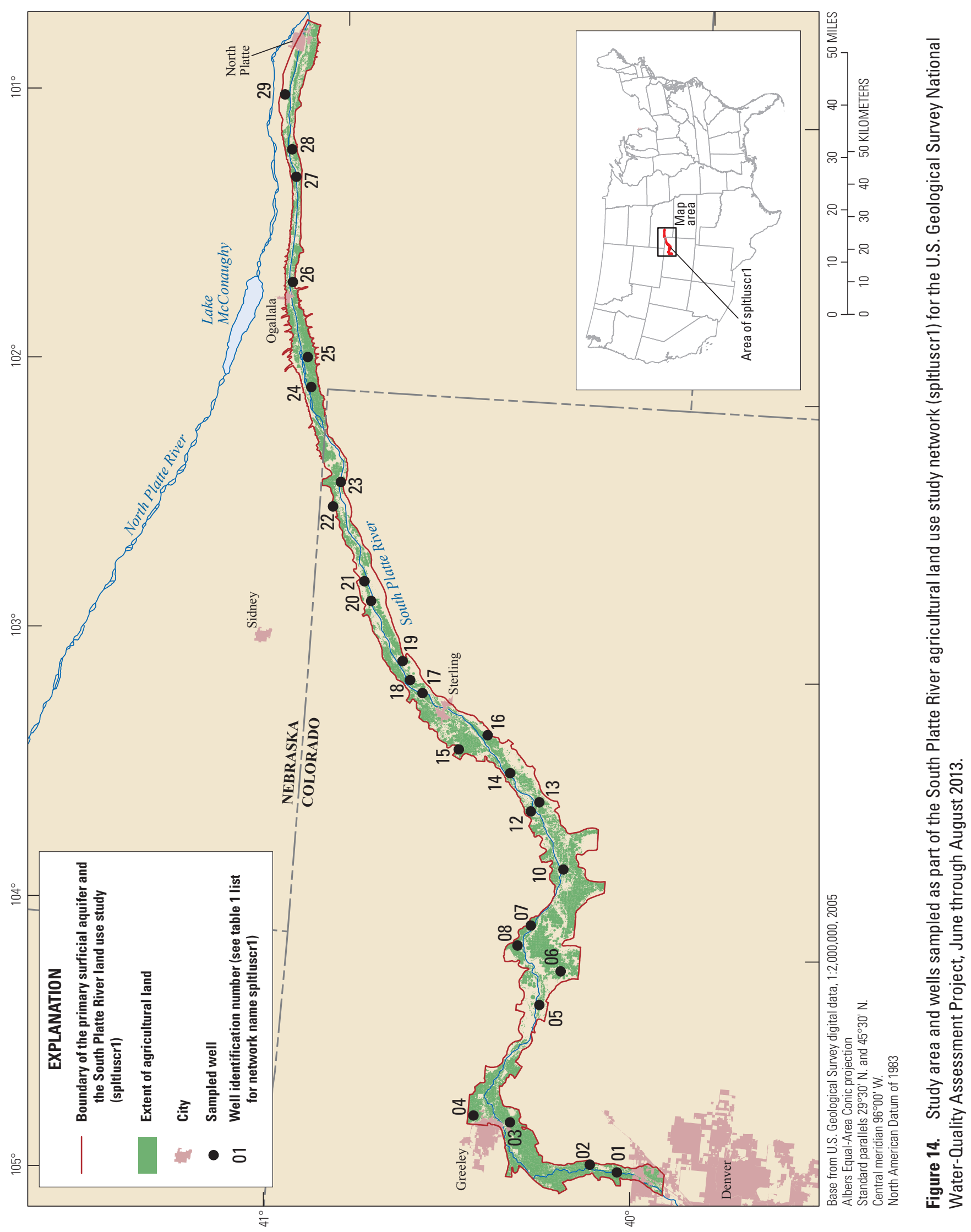


Apalachicola-Chattahoochee-Flint River Basin Agricultural Land Use Study Network (acfbluscr3)

The Apalachicola-Chattahoochee-Flint River Basin agricultural LUS network (acfbluscr3; fig. 9) was designed to characterize the effects of cropland agriculture on shallow groundwater quality in the Upper Floridan and Southeastern Coastal Plain aquifer systems of this region (Frick and others, 1998; the Southeastern Coastal Plain aquifer system is described previously for the secppas1). The study area is in southeastern Alabama and southwestern Georgia and is defined by the intersection of the areal extent of the Claiborne and Upper Floridan aquifers within the Apalachicola-Chattahoochee-Flint River Basin $\left(6,600 \mathrm{mi}^{2}\right)$ and by areas of cropland, pasture, or orchard agriculture $\left(3,600 \mathrm{mi}^{2}\right)$. The Claiborne aquifer, part of the Southeastern Coastal Plain aquifer system, consists of fine to coarse sand with gravel, limestone, and limestone residuum. The Claiborne aquifer underlies and partly grades laterally into the Upper Floridan aquifer, which is a thick sequence of limestone and dolomite (Long, 1989; Miller 1990). Agriculture in this area consists of a broad range of crops and several replantings of some crops during a year (Frick and others, 1998).

The acfbluscr3 includes 30 monitoring wells. Most wells were between 28 and $69 \mathrm{ft}$ deep (table 4-1; appendix 4) and open to the aquifer across 10-ft intervals (table 4-2; appendix 4). The acfbluscr3was previously sampled in 2002-3. Samples for the current phase of monitoring were collected August through September 2013.

\section{Delmarva Peninsula Agricultural Land Use Study Network (dlmvluscr1)}

The Delmarva Peninsula agricultural LUS network (dlmvluscr1; fig. 10) was designed to characterize the effects of the intensive agriculture in this region on shallow groundwater quality. The Delmarva Peninsula is about $6,000 \mathrm{mi}^{2}$ in area and includes most of Delaware and parts of Maryland and Virginia east of the Chesapeake Bay. The area is underlain by the surficial aquifer of the Northern Atlantic Coastal Plain aquifer system (described previously for the nacppas1 and nacppas2). The surficial aquifer consists of unconfined, highly permeable sandy deposits (Debrewer and others, 2005). The surficial aquifer is used for public and private (domestic) supply. Land use is predominantly agricultural. Crops are mainly soybean and corn grown for poultry feed, and the poultry industry is the most significant agribusiness on the Peninsula. Other agriculture in this area includes wheat and small grains, greenhouses and nurseries, dairy farms and sod farms (Debrewer and others, 2005). All agricultural areas, which covered about $2,700 \mathrm{mi}^{2}$ in total, were included in the study area.
The dlmvluscr 1 includes 25 monitoring wells. Most wells were between 13 and $27 \mathrm{ft}$ deep table 4-1; appendix 4) and open to the aquifer across 3 -ft intervals (table 4-2; appendix 4). The dlmvluscrlwas previously sampled as a pilot network for the NAWQA Project in 1988-91 and was resampled in 2001-3 (Denver and others, 2004, 2014; Debrewer and others, 2005). Samples for the current phase of monitoring were collected July through September 2012.

\section{Georgia-Florida Urban Land Use Study Network (gafllusrc1)}

The Georgia-Florida urban LUS network near Tampa, Florida (gafllusrc1; fig. 11), is in the Tampa area of southwest central Florida. The study area for this network consists of residential and commercial land use areas in the Tampa Bay metropolitan area, a total area of $160 \mathrm{mi}^{2}$. This study consists of two subnetworks, gafllusrc1a and gafllusrc1b, and was designed to characterize the quality of recently recharged groundwater in an urban setting in the surficial aquifer (gafllusrc1a) and the underlying Upper Floridan aquifer (gafllusrc1b) The surficial aquifer is an unconfined sand and clay aquifer, about 10 to $60 \mathrm{ft}$ thick (Metz and others, 2007). A clay confining unit separates the surficial aquifer from the Upper Floridan Aquifer in parts of the study area. The Upper Floridan aquifer is a thick sequence of limestone and dolomite with many solution fractures and cavities and is a major source of water in the region and heavily used for public supply (Miller, 1990; Metz and others, 2007).

Wells in the gafllusrc1a network are completed in the surficial aquifer and include nine monitoring wells that are typically between 19 and $39 \mathrm{ft}$ deep (table 4-1; appendix 4) and open to the aquifer along 5-ft intervals (table 4-2; appendix 4). Wells in the gafllusrc1b network are completed in the underlying Upper Floridan aquifer and include 15 monitoring wells that are typically between 33 and $150 \mathrm{ft}$ deep and open to the aquifer along a range of interval lengths. Wells in the galflusrc1a and galflusrc $1 \mathrm{~b}$ networks were previously sampled in 1992 (Berndt and others, 1998, 2014). Samples for the current phase of monitoring were collected July through November 2012.

\section{Nevada Basin and Range Urban Land Use Study Network (nvbrlusrc1)}

The Nevada Basin and Range urban LUS network near Reno and Carson City, Nevada (nvbrlusrc1, fig. 12), was designed to characterize the quality of shallow groundwater underlying residential and commercial land use in the basinfill aquifers of the Truckee Meadows and Eagle Valley alluvial basins. The basin-fill aquifers of Truckee Meadows and Eagle Valley extend over about $94 \mathrm{mi}^{2}$ and $23 \mathrm{mi}^{2}$, respectively, and 
are part of the Basin and Range basin-fill aquifers (described previously for the bnrfpas1; fig. 2). In Truckee Meadows and Eagle Valley, the basin-fill aquifers are made up of gravel, sand, and silt, generally $1,000 \mathrm{ft}$ or more in thickness, interspersed with discontinuous fine-grained confining layers (Schaefer and others, 2007; Huntington, 2010a, 2010b.) Both are open basins, meaning that water flows to adjacent basins. Urban areas, primarily residential and commercial land use, occupy more than one-half of each basin, for a total of about $60 \mathrm{mi}^{2}$.

The nvbrlusrc1 is made up of 30 monitoring wells completed in basin-fill sediments. The wells typically were between 15 and $149 \mathrm{ft}$ deep (table 4-1; appendix 4) and open to the aquifer across 5- to 10-ft intervals (table 4-2; appendix 4). The nvbrlusrc1 was previously sampled in 2002 (Thiros and others, 2015). An earlier urban LUS, in the Truckee Meadows basin only, was sampled in 1994 (Covay and Bevans, 1997; Bevans and others, 1998; Lico, 1998). Samples for the current phase of monitoring in the nvbrlusrc1, were collected April through June 2013. A total of 27 wells were sampled: 16 in the Truckee Meadows area and 11 in the Eagle Valley area (fig. 12).

\section{San Joaquin Valley Agricultural Land Use Study Network (sanjlusor1a)}

The San Joaquin Valley agricultural LUS network (sanjlusor1a; figs. 13a and 13b) was designed to characterize shallow groundwater quality in an orchard or vineyard setting of the eastern San Joaquin Valley, California. The eastern San Joaquin Valley is an area of intensive farming that also has a large urban population. The study area is in the eastern alluvial fans physiographic region, which is part of the Central Valley aquifer system, and has extensive and widespread deposits of coarse-grained sediment (Burow and others, 1998; Thiros, 2010). The study area of about $800 \mathrm{mi}^{2}$ is limited to areas of vineyard agriculture, which is one of the major types of agriculture in the region.

The sanjlusorla is made up of 24 domestic wells, which typically were between 114 and $245 \mathrm{ft}$ deep (table 4-1; appendix 4) and open to the aquifer across intervals of 14 to $50 \mathrm{ft}$ (table 4-2; appendix 4). The sanjlusorla was previously sampled in 1994-95 and in 2001-2 (Burow and others, 1998; Thiros and others, 2015). Data for 23 wells in the sanjlusorla are included in this report (figs. $13 A$ and 13B). Samples for the current phase of monitoring were collected in July 2013.

\section{South Platte River Agricultural Land Use Study Network (spltluscr1)}

The South Platte River agricultural LUS network (spltluscr1, fig. 14) was designed to characterize the effects of irrigated agriculture on shallow groundwater quality in an unconfined alluvial aquifer (Bruce and McMahon, 1998; Paschke and others, 2008; Paschke, 2011). The study is along 300 river miles of the South Platte River in northeastern Colorado and southwestern Nebraska, in an area covering about $1,180 \mathrm{mi}^{2}$. The alluvial aquifer is composed of gravel, sand, and clay deposits filling current and historic stream channels. Land use is mostly agricultural and rural residential. Corn is the major crop, and vegetables and grains also are grown. The study area for the spltluscr1 included the area of the alluvial aquifer and, unlike other agricultural land use networks, was not limited only to areas of agricultural land use.

The spltluscr1 is made up of 29 monitoring wells. Although not specifically within areas of agricultural land use, nearly all wells were within about $300 \mathrm{ft}$ of agricultural land. The wells were typically 13 to $47 \mathrm{ft}$ deep (table 4-1; appendix 4) and open to the aquifer along 10-ft intervals (table 4-2; appendix 4). The spltluscr1 was previously sampled in 1994 and resampled in 2002 (Dennehy and others, 1998; Bruce and McMahon, 1998). Samples for the current phase of monitoring, for 27 wells, were collected June through August 2013.

\section{Decadal Trends Networks-Major Aquifer Study Networks}

The MAS networks were designed to reflect the resource used for domestic supply. The MAS networks generally consist of domestic supply wells but may include public supply wells also. Domestic supply wells typically draw groundwater from shallower depths of the aquifer than do public-supply wells. The MAS areas are determined by the areal extent of the primary aquifer and physiography and are designed to assess the condition of groundwater quality in the most heavily used aquifer in the area. Wells in MAS networks are sampled once per decade to assess temporal trends in water quality. Data from the following MAS networks are included in this report: the Albemarle-Pamlico MAS (albesus7; fig. 15), Delmarva Peninsula MAS (dlmvsus1; fig. 16), GeorgiaFlorida MAS (gaflsus4; fig. 17), and Western Lake Michigan Drainages MAS (wmicsus2; fig. 18). 


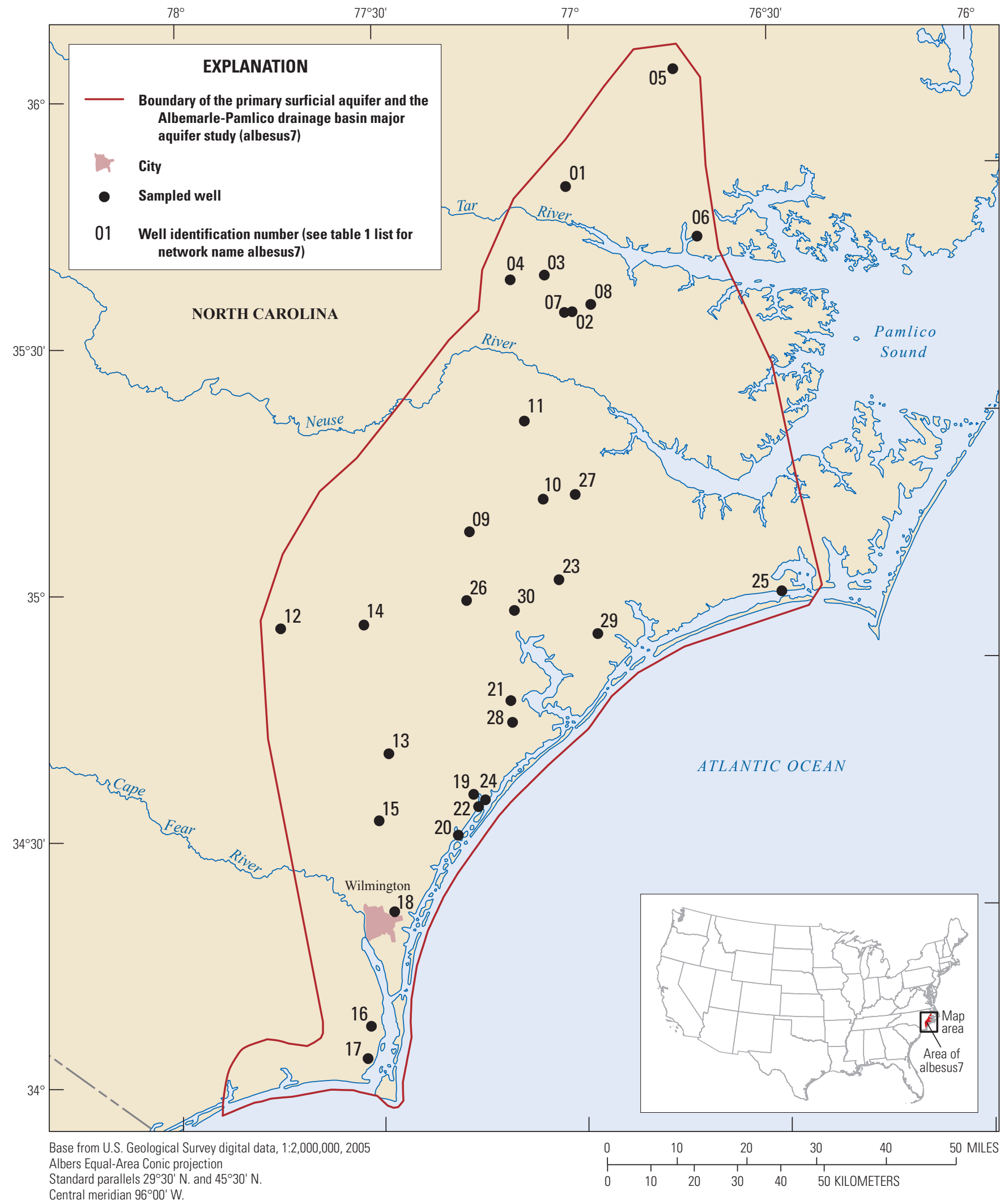

Central meridian $96^{\circ} 00^{\prime} \mathrm{W}$.

Figure 15. Study area and wells sampled as part of the Albemarle-Pamlico major aquifer study network (albesus7) for the U.S. Geological Survey National Water-Quality Assessment Project, June through September 2013. 


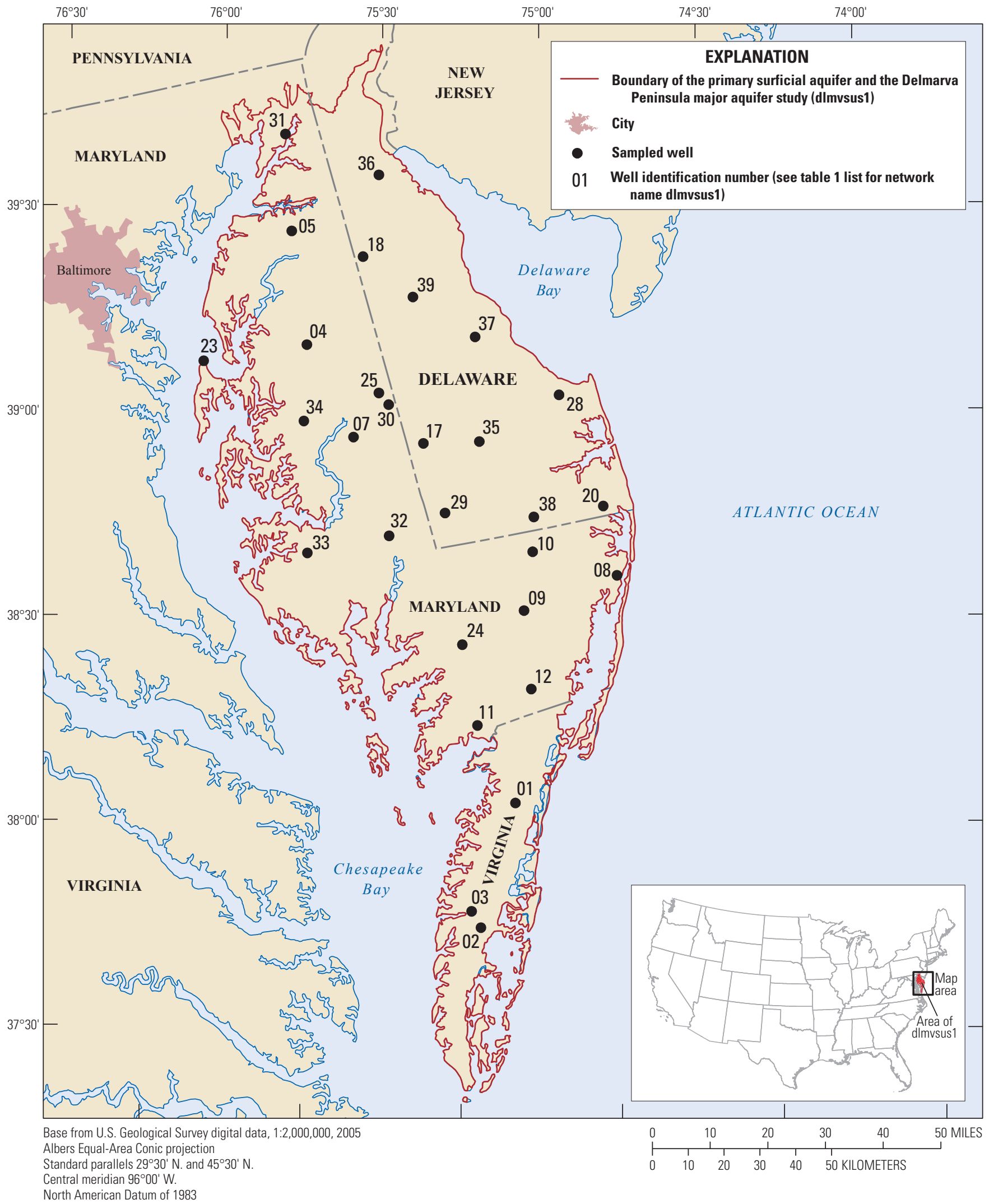

Figure 16. Study area and wells sampled as part of the Delmarva Peninsula major aquifer study network (dlmvsus1) for the U.S. Geological Survey National Water-Quality Assessment Project, June through August 2013. 


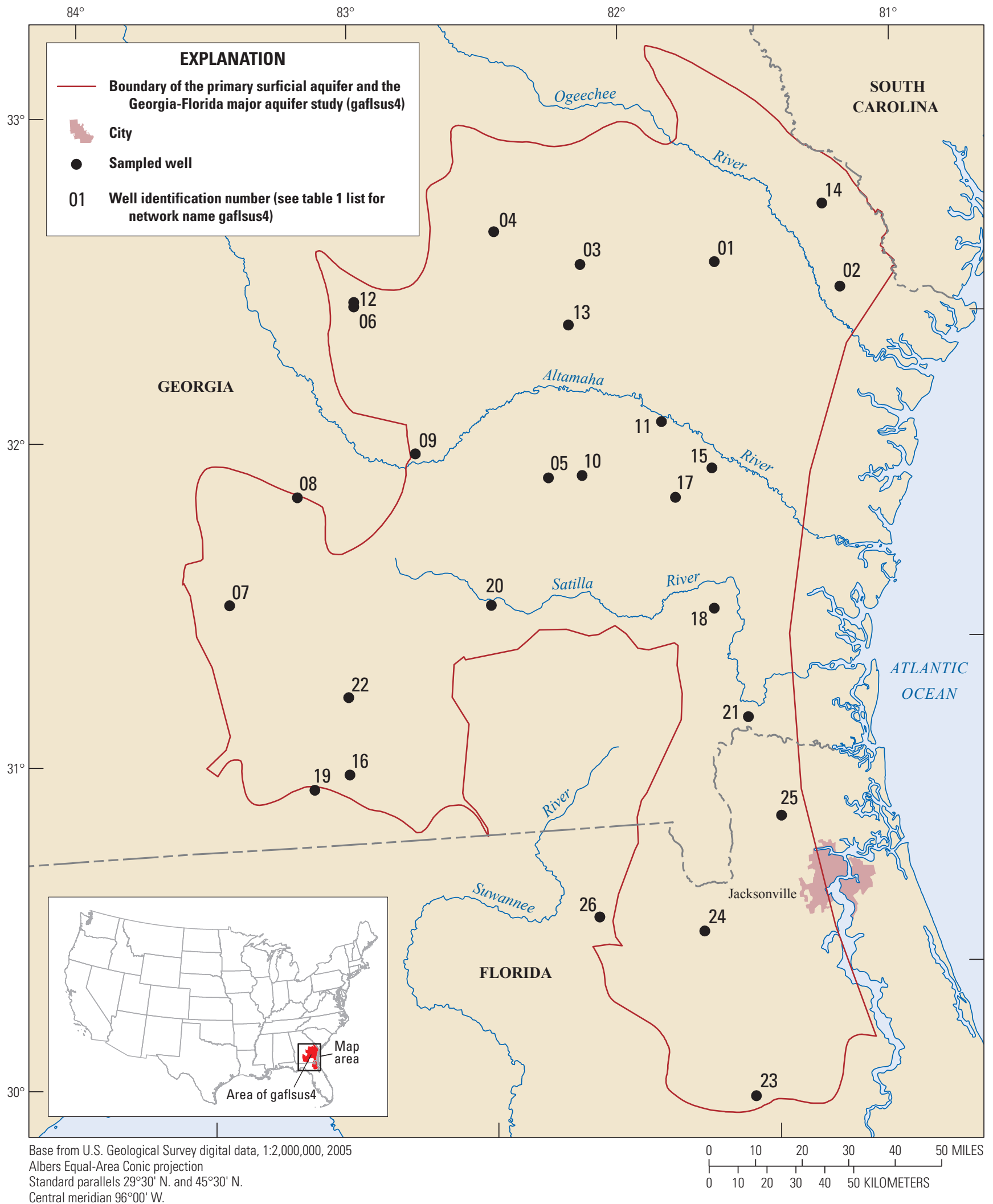

Figure 17. Study area and wells sampled as part of the Georgia-Florida major aquifer study network (gaflsus4) for the U.S. Geological Survey National Water-Quality Assessment Project, June through September 2013. 


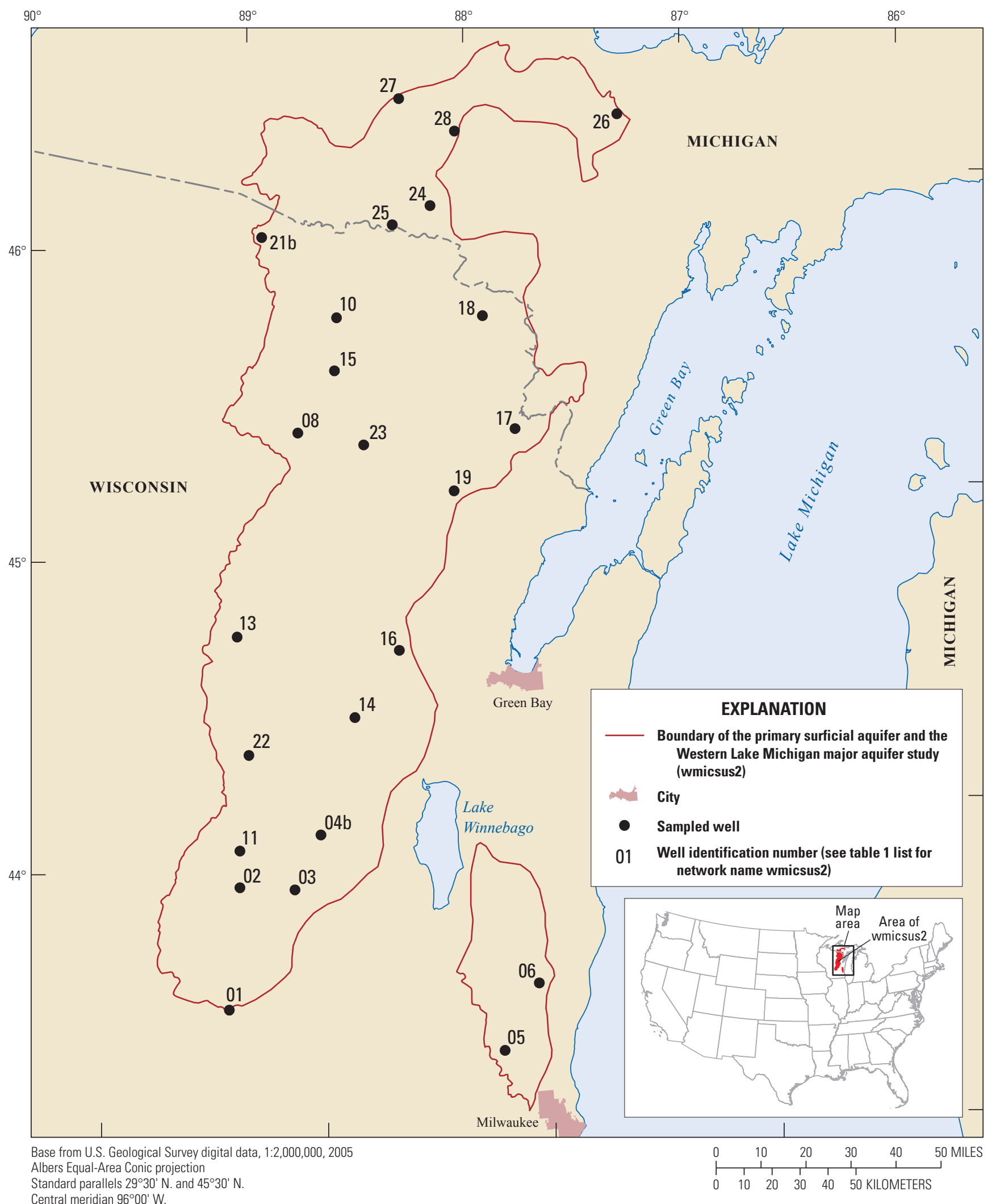

Central meridian $96^{\circ} 00^{\prime} \mathrm{W}$.

Figure 18. Study area and wells sampled as part of the Western Lake Michigan drainages major aquifer study network (wmicsus2) for the U.S. Geological Survey National Water-Quality Assessment Project, July through August 2013. 


\section{Albemarle-Pamlico Drainage Basin Major Aquifer Study Network (albesus7)}

The Albemarle-Pamlico drainage basin MAS network (albesus7, fig. 15), in eastern North Carolina, was designed to characterize the quality of groundwater used for water supply in the Castle Hayne aquifer. The Castle Hayne aquifer is part of the Northern Atlantic Coastal Plain aquifer system (described previously for the nacppas1 and nacppas2) (Masterson and others, 2013), and is an extremely productive limestone aquifer in North Carolina (Trapp and Horn, 1997; Ator and others, 2005). The study area of 5,900 $\mathrm{mi}^{2}$ is defined by areas where the Castle Hayne aquifer is unconfined or overlain by a thin confining layer (Ator and others, 2005).

The albesus 7 is made up of 30 wells; most are monitoring wells, but several domestic and public-supply wells also are included. The albesus 7 has four wells that also are in the nacppas 2 network (table 1). The wells typically were 60 to 204 ft deep (table 4-1; appendix 4) and open to the aquifer along intervals of 10 to $90 \mathrm{ft}$ (table 4-2; appendix 4). The network was previously sampled in 2002-3 (Denver and others, 2014). Samples for the current phase of monitoring were collected June through September 2013.

\section{Delmarva Peninsula Major Aquifer Study Network (dlmvsus1)}

The Delmarva Peninsula MAS network (dlmvsus1, fig. 16) was designed to characterize the quality of groundwater used for water supply in the surficial aquifer of the Delmarva Peninsula (Denver and others, 2004). The Delmarva Peninsula is about 6,000 $\mathrm{mi}^{2}$ and includes most of Delaware and parts of Maryland and Virginia east of the Chesapeake Bay. The surficial aquifer in this area is the shallowest aquifer of the Northern Atlantic Coastal Plain aquifer system (described previously for the nacppas1 and nacppas2). The aquifer is composed of unconfined, highly permeable sandy deposits (Debrewer and others, 2005). The surficial aquifer is used for public and private (domestic) supply.

The dlmvsus 1 is made up of 29 wells, mostly monitoring or domestic wells. The wells typically were 28 to $95 \mathrm{ft}$ deep (table 4-1; appendix 4) and open to the aquifer along intervals of 3 to $20 \mathrm{ft}$ (table 4-2; appendix 4). The dlmvsus 1 was previously sampled as a pilot network for the NAWQA Project in 1988-90 and resampled in 2001-2 (Denver and others, 2004, 2014). Samples for the current phase of monitoring were collected June through August 2013.

\section{Georgia-Florida Major Aquifer Study Network (gaflsus4)}

The Georgia and Florida MAS network (gaflsus4, fig. 17) was designed to characterize the quality of groundwater used for water supply in the confined part of the Upper Floridan aquifer. The Upper Floridan aquifer is a thick sequence of limestone and dolomite that is heavily used for water supply in several southeastern states (Miller, 1990). A low-permeability sequence of sand, clay, marl, limestone, and dolomite overlies the Upper Floridan aquifer over much of its areal extent (Berndt and Crandall, 2009). The study area for the gaflsus4 is defined by areas in southeastern Georgia and northeastern Florida where these low-permeability sediments form a confining unit of more than $100 \mathrm{ft}$ in thickness, a total area of about $18,000 \mathrm{mi}^{2}$.

The gaflsus 4 includes 30 domestic wells. Data for 26 wells are included in this report. The wells typically were 230 to $700 \mathrm{ft}$ deep (table 4-1; appendix 4) and have a wide range of open intervals (table 4-2; appendix 4). The gaflsus4 was previously sampled in 2005 (Berndt and Crandall, 2009; Berndt and others, 2014); samples for the current phase of monitoring were collected June through September 2013.

\section{Western Lake Michigan Drainages Major Aquifer Study Network (wmicsus2)}

The Western Lake Michigan drainages MAS network (wmicsus2, fig. 18) was designed to characterize the quality of groundwater in the parts of the glacial aquifer that are most heavily used for water supply in that area. The Western Lake Michigan drainages includes those parts of eastern Wisconsin and the Upper Peninsula of Michigan that drain to Green Bay and Lake Michigan (Peters and others, 1998). The wmicsus2 area covers about $10,600 \mathrm{mi}^{2}$ and is defined by the areal extent of coarse-grained glacial deposits near public-supply wells within the drainages boundary. Glacial deposits are throughout this region; however, they are most heavily used for water supply where the deposits are thick and permeable and where other aquifers are too thin or unproductive to be a reliable source of water. This includes primarily the eastern part of Wisconsin near Green Bay and a smaller area of heavy use northwest of Milwaukee, Wisconsin.

The wmicsus 2 includes 30 wells, mostly domestic use. The wells typically were 49 to $140 \mathrm{ft}$ deep (table 4-1; appendix 4) with 3- to 4-ft open intervals (table 4-2; appendix 4). A total of 28 wells in the network were previously sampled in 2003 (Warner and Ayotte, 2014); samples for the current phase of monitoring were collected from 24 wells during July and August 2013. 


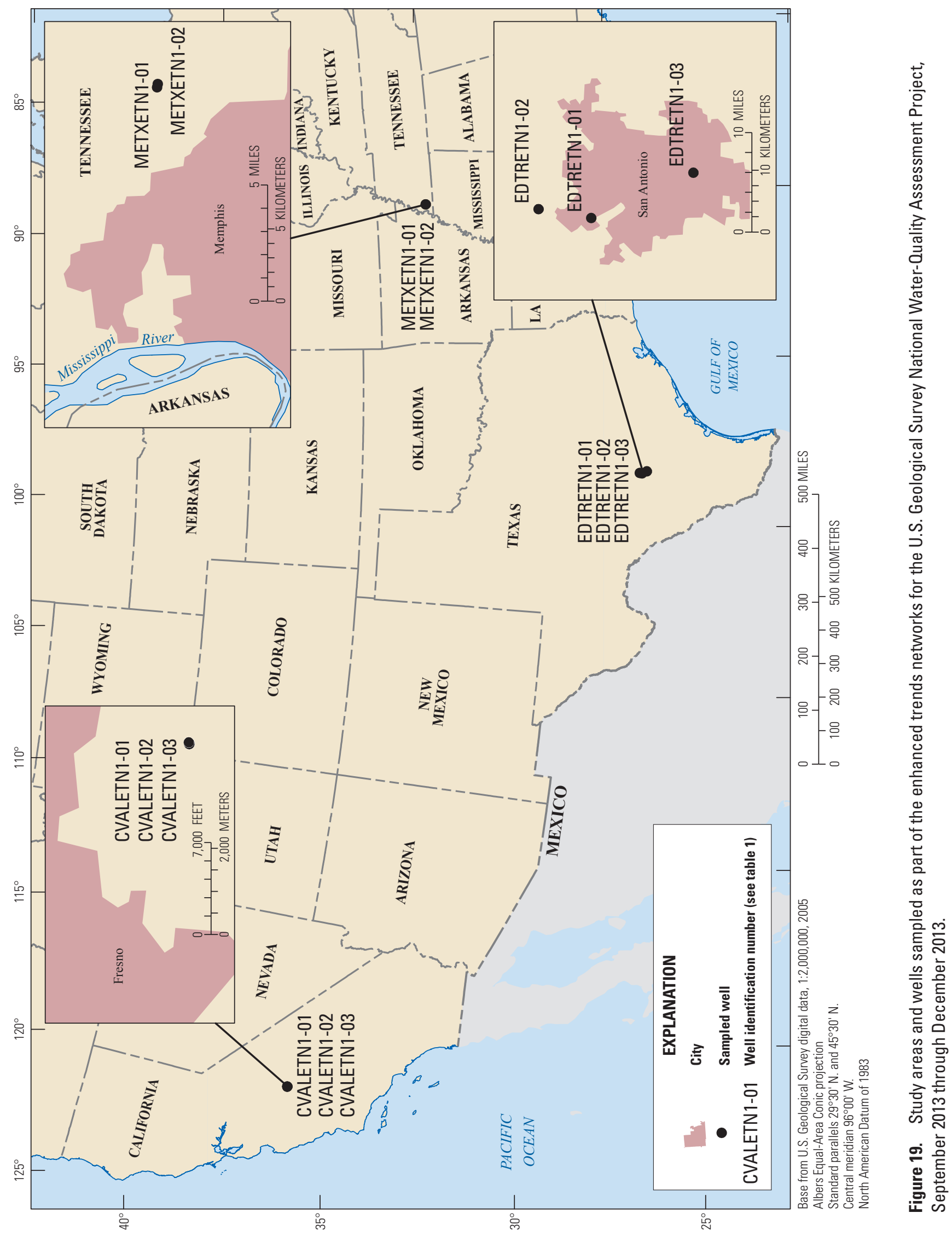




\section{Enhanced Trends Networks}

Enhanced trends networks (ETNs) consist of a small number of wells (typically two to four) that are sampled frequently to evaluate the time scales during which groundwater quality changes. Such changes might result from seasonal or annual variability in recharge, discharge, or contaminant loading (Rowe and others, 2013). Data from three ETNs are included in this report: the Central Valley ETN (cvaletn1; fig. 19), Mississippi Embayment ETN (metxent1; fig. 19), and Edwards-Trinity ETN (edtetn1; fig. 19). Wells in ETNs are instrumented for high-frequency measurement of some parameters and sampled once every 2 months for 4 -year periods and annually for subsequent or preceding 4 -year periods. Data collected at a high frequency for wells in the ETNs are available on the Web; links to the data are provided in appendix 1.

\section{Central Valley Aquifer System Enhanced Trends Network (cvaletn1)}

The enhanced trends network in the Central Valley aquifer system (cvaletn1; fig. 19) is intended to aid in the understanding of the subsurface movement of groundwater constituents (in some cases contaminants from land use practices) between the shallow and deep parts of the aquifer system. The network is near Fresno, California, in the southeastern San Joaquin Valley. The site is situated on the Kings River alluvial fan, a topographically flat area just west of the foothills of the Sierra Nevada. The climate in the southeastern San Joaquin Valley is Mediterranean, characterized by hot, dry summers and cool, moist winters. Average annual rainfall in the city of Fresno is about 11 inches (in.), with more than 90 percent of the precipitation falling between October and April (Western Regional Climate Center, 2015). Historically, land use was predominantly agricultural but, during the last 30 years, has become increasingly urban.

The regional aquifer in the study area consists of three interconnected, unconfined alluvial layers: fluvial deposits of the Modesto and Riverbank Formations, coarse alluvium of the Turlock Lake Formations and North Merced Gravels, and finer grained continental sediments of the Laguna Formation (Marchand and Allwardt, 1981; Burow and others, 1997). The city of Fresno and its population of more than 500,000 (2013) rely almost exclusively on groundwater from this regional aquifer for water supply (City of Fresno, 2015). Groundwater flow and quality in the regional aquifer supplying Fresno are affected by human activities. Because of intensive pumping and irrigation recharge, groundwater flows downward rather than following the regional flow gradient southwest toward the axis of the San Joaquin Valley. Nitrate and the persistent soil fumigant 1,2-dibromo-3-chloropropane exceed EPA maximum contaminant levels (MCLs) in groundwater supplies in the area (Dubrovsky and others, 1998; Wright and others, 2004; Burow and others, 2007; Burton and Belitz, 2008; University of California, 2012; California State Water Resource Control Board, 2015).

The cvaletn 1 is made up of three wells, two shallow and one deep, which represent different depths in the regional aquifer (table 1). Two wells (CVALETN1-03, $224 \mathrm{ft}$ deep; and CVALETN1-02, $320 \mathrm{ft}$ deep; table 1) are screened in the Turlock Lake Formations and the North Merced Gravels. These wells produce water that exceeds the MCLs for nitrate and 1,2-dibromo-3-chloropropane. The third well, (CVALETN1-01, $620 \mathrm{ft}$ deep; table 1), is screened in the underlying Laguna Formation. Chemical data show that groundwater from this well is currently (as of 2013) unaffected by downward movement of shallow groundwater. The three wells are within about $50 \mathrm{ft}$ of one another and are 3 miles west of NAWQA Project flow path and agricultural LUS wells (Burow and others, 1999). The CVALETN1-02 and CVALETN1-01 were sampled by the USGS Groundwater Ambient Monitoring and Assessment Program in 2005 (Burton and Belitz, 2008), and sampling of CVALETN1-02 as part of the flow path study is planned. All three wells in the cvaletn1 were sampled once in September 2013, and two of the wells also were sampled in November 2013; these data are included in this report.

\section{Mississippi Embayment Aquifer System Enhanced Trends Network (metxetn1)}

The enhanced trends network in the Mississippi Embayment aquifer system (metxetn1; fig. 19) was designed to study how water quality in shallow and deep parts of the regional aquifer changes in response in changing hydrologic conditions and pumping. The network is at one of the water-supply facilities for the city of Memphis, Tennessee, in the northcentral part of the Mississippi Embayment. Topography is gently rolling, and the climate is subtropical with an average annual precipitation of about 54 in. (National Oceanic and Atmospheric Administration, 2014b). Land use in the area is predominantly commercial and residential.

The Mississippi Embayment aquifer system consists of several thousand feet of sand, silt, and clay that fill a broad structural depression in the underlying bedrock (Cushing and others, 1964). The city of Memphis and surrounding municipalities rely on one of the regional aquifers in this system, the Memphis aquifer, as their primary source of water supply. The Memphis aquifer is about 500 to $900 \mathrm{ft}$ thick and is composed primarily of sand. It is overlain by a shallow aquifer and by a confining unit; but the confining unit is thin or absent in some areas (Parks, 1990). Groundwater quality in the shallow aquifer has been affected by the overlying land use, as indicated by the presence of elevated nitrate, chloride, pesticides, and volatile organic compounds (Gonthier, 2002; Barlow and others, 2012); these contaminants have the potential to move down into the underlying Memphis aquifer (Graham and Parks, 1986; Parks, 1990; Parks and others, 1995; Clark and Hart, 2009). 
The metxetn1 consists of one well in the shallow aquifer (METXETN1-02, $90 \mathrm{ft}$ deep) and one well in the Memphis aquifer (METXETN1-01, $624 \mathrm{ft}$ deep) (table 1). The wells are about $940 \mathrm{ft}$ apart. Although groundwater does not follow a direct flow path from the shallow well to the deep well, water levels indicate that groundwater moves downward from the shallow aquifer to the Memphis aquifer through a window in the confining layer about 1.5 miles from the site (Welch and others, 2009). The shallow well produces groundwater that is typical of recent recharge to the shallow aquifer; groundwater from the deep well is currently unaffected by downward movement of shallow groundwater. The wells are within the area of a previously sampled study of the shallow aquifer underlying Memphis (miselusrc1; Kleiss and others, 2000; Gonthier, 2002), and METXETN-02 was sampled as part of the flow path study in the Mississippi Embayment aquifer system in 2013. Wells in the metxetn1 were sampled once in August, November, and December 2013; and these data are included in this report.

\section{Edwards-Trinity Aquifer System Enhanced Trends Network (edtetn1)}

The enhanced trends network Edwards-Trinity aquifer system (edtetn1; fig. 19) is designed to evaluate temporal variability in groundwater quality in a dynamic karst aquifer. The network is in the Edwards (Balcones Fault Zone) aquifer in south-central Texas. Central Texas is characterized as subhumid to semiarid, with hot summers and mild winters (Larkin and Bomar, 1983). Average annual rainfall in San Antonio is 29 in. but is highly variable (National Oceanic and Atmospheric Administration, 2014a). The aquifer is present in a narrow band along the Balcones Escarpment, below which the aquifer dips steeply to the south and southeast; relief across the Balcones Escarpment ranges from about 100 to $500 \mathrm{ft}$. Land use is predominantly undeveloped rangeland, with small amounts of agricultural and urban land. The region is prone to climatic and hydrologic extremes (Griffiths and Straus, 1985; Jones, 1991) and often cycles between very wet and very dry conditions that affect aquifer water levels, spring flow, water quality, and contaminant transport (Mahler and others, 2006; Musgrove and others, 2010, 2011; Wong and others, 2012).

The Edwards aquifer, which is the primary water supply for more than 2 million people in south-central Texas, is developed in Cretaceous-age carbonates that are extensively faulted, fractured, and karstified. The aquifer is divided into three zones: the contributing, unconfined (recharge), and confined zones. Streams flowing south and east drain the contributing zone and recharge the Edwards aquifer by streamflow loss across the unconfined (recharge) zone. The confined zone is overlain by thick layers of clastic sediments. In addition to losing streams, other karst features, such as sinkholes and caves, supply recharge to the aquifer and provide direct interaction between surface water and groundwater (Sharp and Banner, 1997).
There are three wells in the edtetn1. The wells are along an approximately north-to-south aquifer transect within the San Antonio metropolitan area (fig. 19). One well is in the upgradient, unconfined recharge zone, and two wells are downgradient in the confined zone. The upgradient well (EDTRETN1-02) is $300 \mathrm{ft}$ deep and open to the aquifer along the bottom $80 \mathrm{ft}$ of its length (table 1). The downgradient wells are 550 (EDTRETN1-01) and 1,500 (EDTRETN1-03) ft deep and are open to the aquifer throughout their length below the confined zone (table 1). The furthest downgradient well (EDTRETN1-03) is close to the aquifer's southern boundary. The wells are expected to represent a gradient of karst conditions, with greater temporal variability at the upgradient well and lower variability at the downgradient wells. The upgradient well has been sampled periodically as part of a study of groundwater quality in the urban San Antonio recharge zone of the Edwards aquifer (sctxlusrc1; Bush and others, 2000). Wells in the edtetn 1 were sampled in November and December 2013, and these data are included in this report.

\section{Sample Collection and Analysis}

During May 2012 through December 2013, samples were collected for environmental assessment and quality assurance from 748 wells (fig. 1; table 1). Groundwater samples were collected and processed using methods designed to yield samples that were representative of environmental conditions, minimally affected by contamination, and consistent nationwide (Koterba and others, 1995; Lapham and others, 1995, U.S. Geological Survey, variously dated). All samples were collected at the wellhead (the point at which the groundwater exits the well near land surface), or as close to the wellhead as possible, before any treatment or blending potentially could alter constituent concentrations. Samples were collected and processed using prescribed protocols described in Koterba and others (1995), Lapham and others (1995), and the USGS National Field Manual (U.S. Geological Survey, variously dated). Samples were analyzed at the USGS National WaterQuality Laboratory in Denver, Colorado, for all constituents except four radionuclides. These constituents (lead-210, polonium-210, radium-224, and radium-226) were analyzed by TestAmerica in Richlands, Washington.

Groundwater samples were analyzed for water-quality indicators, nutrients and dissolved organic carbon, major and minor ions, trace elements, VOCs, pesticides, and radiochemistry. The constituents for which samples were collected are listed in table 2 and organized by constituent class; constituent primary uses and sources; analytical schedules and sampling period; analytical method references; USGS parameter codes; comparison thresholds; reporting levels; number of analyses, detections, and detections above the reporting level; and the table in which the data for the constituent class is shown. Analytical schedules are groups of constituents for which laboratory analysis is requested. The USGS parameter code 
identifies the constituents and indicates the laboratory method used to analyze the samples. The reported concentration of a constituent can be evaluated using the comparison threshold value. Of the comparison thresholds listed in table 2, only the secondary maximum contaminant level is not health based.

Analytical methods for VOCs and pesticides changed during the period of data collection included in this report. Analytical methods and analytical schedules used in 2012 for VOCs and pesticides were the same as were used in previous NAWQA Project groundwater studies: VOCs were provided through analytical schedule S2020 and pesticides through schedules S2033 and S2060 (Gilliom and others, 2006; Zogorski and others, 2006; DeSimone and others, 2014). In 2013, new analytical methods and analytical schedules were used. The new methods for VOCs were provided through schedules S4436 (purge and trap gas chromatography/mass spectrometry) and S4437 (heated purge and trap gas chromatography/mass spectrometry) (Rose and others, 2016), and the new methods for pesticides were provided through schedule S2437 (direct aqueous infection liquid chromatography tandem mass spectrometry) (Sandstrom and others, 2016).

In addition to discrete water-quality samples that are collected periodically, the ETN wells also are instrumented to measure basic water-quality parameters at a high frequency during specific periods throughout each day. Each well is instrumented with a water-quality sonde that contains temperature, conductance, $\mathrm{pH}$, and dissolved oxygen probes. The sonde sits in a flow through chamber that receives groundwater flow from near the well head. Measurements of the basic water-quality parameters are made when the well is pumping and groundwater is flowing through the system, which may range from 1 to 24 hours per day. Water-quality data are recorded by the sonde every 2 minutes to 12 hours, depending on the network. The water-quality data are transmitted to a data collection platform where the data are stored and transmitted to the USGS National Water Information System Web (U.S. Geological Survey, 2012) database by the Geostationary Operational Environmental Satellite network. The high-frequency data are reviewed, corrected, and approved according to recommendations for working continuous water-quality records (Wagner and others, 2006).

\section{Data Reporting}

Several conventions are used for the concentrations of constituents that are reported as not detected in water-quality samples (censored data or concentrations that are reported as "less than" a specified value). Inorganic constituents (major ions, nutrients, and trace elements) are reported using longterm method detection levels (LT-MDL) as the reporting levels. The LT-MDL is the smallest concentration that can be measured and reported with 99 percent confidence that the concentration is greater than zero (Childress and others, 1999). The LT-MDL is similar to a method detection level (MDL;
U.S. Environmental Protection Agency, 2015), with the added characteristic that it is determined from statistical analysis of laboratory quality-control (QC) data during an extended period (Bonn, 2008). Organic constituents (VOCs and pesticides) are reported using laboratory reporting levels (LRLs). An LRL for a constituent is typically about 2-fold greater than its LT-MDL and is defined as the concentration at which the chance of a false negative error is 1 percent (that is, there is 99 percent confidence at the LRL that a constituent has been correctly reported as absent) (Childress and others, 1999).

The LRL is more protective against the chance of false negative errors - that is, the chance of incorrectly reporting that a constituent is absent in a water sample when it actually is present- than the LT-MDL. The LT-MDL is defined in terms of false positive errors, for concentrations near the LT-MDL, the chance of incorrectly reporting that a constituent is present in a water sample when it is actually absent (concentration equal to zero) is 1 percent; however, the chance of a false negative error (incorrectly reporting that the constituent is absent when it actually is present) at the LT-MDL is 50 percent, in contrast to the 1 percent chance of a false negative error at the LRL. In other words, if a value is reported as less than an LRL, there is only a very small chance that it is present at a concentration greater than the LRL, whereas if a value is reported as less than an LT-MDL, there is a 50 percent chance that it is present at a concentration near but above the LT-MDL. The LRLs are used for reporting analytical results for VOCs and pesticides to allow for the robust analysis and interpretation of detection frequencies. The analytical methods for these constituents use gas chromatography or high-performance liquid chromatography. Such methods are considered information rich; therefore, the National WaterQuality Laboratory often provides results that indicate the presence of these constituents at concentrations less than their LRLs. This report includes such results in tables 7 and 8 for completeness; however, for each well, detection summaries in these tables are tabulated for total detections and for number of detections above the LRL.

A few constituents (for example, nitrate plus nitrite) are reported using MDLs or minimum reporting levels. The MDLs are calculated according to the U.S. Environmental Protection Agency (EPA) definition of an MDL, described previously, as the minimum concentration of a substance that can be measured and reported with 99 percent confidence that the value is above zero (Patton and Kryskalla, 2011; U.S. Environmental Protection Agency, 2015) . A minimum reporting level is a reporting level that is chosen by the laboratory but is not necessarily associated with any specific method of determination or statistical certainty (Bonn, 2008).

Radionuclides are reported using units of radioactive activity (picocuries per liter) rather than concentration. Reporting levels for these constituents are based on the sample-specific critical level ( $\mathrm{ssL}_{\mathrm{c}}$ ) or sample-specific minimum detectable concentrations (ssMDCs) (McCurdy and others, 2008). Both the $\mathrm{ssL}_{\mathrm{c}}$ and $\mathrm{ssMDC}$ are calculated for each sample from parameter values used during the actual analysis of the sample. 
The $\mathrm{ssL}_{\mathrm{c}}$ and ssMDC are analogous to the LT-MDL and LRL, respectively. The $s s L_{c}$ is defined as the smallest measured activity that indicates detection of the radionuclide, with no more than a 5 percent chance of a false positive detection (the specified probability associated with a critical level can vary but is typically 5 percent for radionuclides) (U.S. Environmental Protection Agency, 2004). Like the LT-MDL, the $\mathrm{ssL}_{\mathrm{c}}$ is a reporting level that is based on a specified probability of false positive errors - that is, incorrectly reporting that the radionuclide is present when it is actually absent. The ssMDC, like the LRL, is a reporting level that is based on a specified probability of false negative errors - that is, failing to report that the radionuclide is present. The ssMDC is defined as the activity at which there is 5 percent chance of a false negative error and typically about 2-fold larger than the $\mathrm{ssL}_{\mathrm{c}}$ (McCurdy and others, 2008).

The analytical methods for VOCs and pesticides in schedules 2437, 4436, and 4437 (table 2) are new methods that were still in the process of USGS approval when samples were analyzed. Results for laboratory methods that are unapproved generally are not made publicly available by the USGS because the quality of the results could potentially be affected by problems subsequently discovered during the process of method approval. For schedules 2437, 4436, and 4437, the method approval process revealed no substantial problems and resulted in no changes in the analytical process (Duane Wydoski, U.S. Geological Survey, written commun., 2015), indicating that the data reported before method approval for these methods were of sufficient quality for public release; however, LRLs for individual compounds may be adjusted as additional QC data for the method are obtained and examined. The data from schedules 2437, 4436, and 4437 are reported relative to interim reporting levels, which are similar to LRLs.

Concentration values below LT-MDLs, and concentration values between LT-MDLs and LRLs, are reported without any qualifiers in this report. Values below LT-MDLs or between LT-MDLs and LRLs can be identified by comparing the reported concentrations with the LT-MDLs and LRLs listed by compound in table 2. It is important to note that there is greater uncertainly associated with values less than LT-MDLs (regarding risk of false positive errors or inaccurate detections) and with values less than LRLs (regarding risk of false negative values or inaccurate nondetections) than with values that are greater than LT-MDLs, LRLs, or both.

\section{Quality-Assurance and Quality-Control Methods}

The quality-assurance plan for NAWQA Project groundwater samples was derived from previous NAWQA Project cycles of study (Koterba and others, 1995) and the USGS National Field Manual (U.S. Geological Survey, variously dated). About 14 percent of samples collected during any period are for data quality assurance and QC. Types of QC samples include equipment blanks, source solution blanks, field blanks, replicates, field spikes, and laboratory spikes. Results of statistical analysis of blank and replicate QC samples are presented in appendix 3. Results of statistical analysis of spike samples will be presented in a later publication.

Blanks are used to test for bias from an unintentional introduction of contamination to environmental samples. Equipment blanks are for testing that equipment is clean and free of contamination. Source solution blanks are used to test that the water used for the blank sample is free of contamination. Field blanks are used to test for contamination that may be introduced during sample collection, processing, handling, and analysis; and from the environment around where the sample was collected. Replicates are samples that are collected at the same time using the same method as the environmental sample. Replicates measure the variability of determining a concentration in samples that should be essentially identical. Spiked samples are used to measure the performance of analytical methods on an environmental water sample. A sample can be spiked in the field or the laboratory.

The number and type of QC samples planned for each network study depend on the number of wells sampled, the number of sampling teams that are involved in the sampling, and the constituents for which samples will be analyzed:

- Equipment blanks are collected for nutrients, trace elements, and VOCs at the quantity of one blank for each team sampling the network.

- Source solution blanks are collected for nutrients, trace elements, and VOCs at the quantity of one blank for each team sampling the network. The VOCs have additional source solution blanks that are collected with each field blank.

- Field blanks are collected for major ions, nutrients, dissolved organic carbon, trace elements, and pesticides at the quantity of 1 blank for every 15 wells sampled or 1 blank for each team sampling the network (whichever results in a greater number of blanks). Field blanks are collected for VOCs at the quantity of 1 blank for every 10 wells sampled or 1 blank for each team sampling the network (whichever results in a greater number of blanks).

- Replicate samples are collected for major ions, nutrients, dissolved organic carbon, trace elements, VOCs, and radionuclides at the quantity of 1 replicate for every 30 wells sampled. Replicate samples are collected for pesticides at the quantity of 1 replicate for every 15 wells.

- Field spikes are collected for pesticides at the quantity of 1 spike sample for every 30 wells sampled.

- Laboratory spikes are collected for VOCs at the quantity of 1 spike sample for every 30 wells sampled. 
Statistical analysis of QC sample data can be used to evaluate the variability or bias of the data, sampling and sample handling procedures, and laboratory and (or) field methods; and to ensure the environmental assessment samples represent true groundwater chemistry. The QC sample data provided in this report include water quality for blank and replicate QC samples collected between May 2012 and December 2013 in association with the environmental sample data included in tables 3 to 11 (available for download at http://dx.doi.org/10.5066/F7HQ3X18). Field- and laboratoryspike data are not presented in this report. The QC data are provided in appendix 3. Additionally, an analysis is provided in appendix 3 of blank QC data, in which the number and concentrations of constituents detected in blank samples are described. The analysis of blank QC data is based on samples collected from May 2012 through September 30, 2013.

\section{Groundwater-Quality Data}

Groundwater samples were collected at 748 wells between May 2012 and December 2013 (table 1). Samples were analyzed for about 480 constituents (table 2); however, not all wells were sampled for all constituents. Results of analyses are presented in tables $3-11$, which are organized by constituent class: water-quality indicators (table 3 ), nutrients and dissolved organic carbon (table 4), major and minor ions (table 5), trace elements (table 6), VOCs (tables 7 and 8), pesticides (table 9 and 10), and radiochemistry (table 11). Data for all wells that were sampled for the associated constituent group are presented in tables 3-11. All wells that were sampled during the time period represented by this report are listed in table 1 . The constituents for which samples were analyzed and the table in which the data are presented are listed in table 2. Comparative benchmarks (thresholds), listed in table 2, provide context for evaluating the constituent concentration data in terms of human health and other characteristics relevant for drinking-water use. There are several types of thresholds listed. The EPA MCLs are legally enforceable drinking-water standards that specify the maximum permissible level of a constituent that can be delivered to a user of a public water system. The EPA Human-Health Benchmarks for Pesticides (HHBPs) are nonenforceable screening levels for evaluating if a pesticide concentration in drinking-water sources may indicate a potential human-health risk (U.S. Environmental Protection Agency, 2012). The HHBPs include benchmarks for cancer and noncancer health effects (U.S. Environmental Protection Agency, 2013). The USGS Health-Based Screening Levels (HBSLs) are nonenforceable benchmarks for constituents that do not have MCLs or HHBPs that can be used to evaluate if constituent concentrations may indicate a potential human-health concern (Toccalino, 2007; Toccalino and others, 2014). Like EPA HHBPs, USGS health-based screening levels are categorized in terms of cancer and noncancer health effects.
The groundwater-quality data are presented in the format of tab-delimited ASCII text files. These ASCII files are referenced as tables 1 through 11 and A3-2 through A3-15 in the report but are provided as separate electronic files for download at http://dx.doi.org/10.5066/F7HQ3X18. Each file includes metadata that describes the source and content of the file. Metadata lines are indicated by the pound symbol (\#), and the last line of the metadata is numbered. The first line after the metadata contains the column headings for the tab-delimited data columns. The data may be imported into spreadsheet, database, or statistical software for manipulation and analysis.

\section{Water-Quality Indicators}

Water-quality indicators include water temperature, dissolved oxygen, specific conductance, $\mathrm{pH}$, alkalinity, carbonate and bicarbonate (calculated from alkalinity), and turbidity (table 3). Water-quality indicators are measured in the field when the other water samples are collected (U.S. Geological Survey, variously dated) and are sometimes also measured in the laboratory ( $\mathrm{pH}$ and specific conductance).

Water-quality indicators provide basic information on the general quality and geochemical conditions of the water. Dissolved oxygen is the concentration of oxygen dissolved in the water and is an indicator of redox conditions in the aquifer. Measurements of $\mathrm{pH}$ indicate the acidity/basicity of water. Dissolved oxygen and $\mathrm{pH}$ are important controls on the chemical reactions that can occur in water. Specific conductance is a measure of how well the water conducts electricity and indicates the relative amount of dissolved solids in the water. Alkalinity, carbonate, and bicarbonate indicate the hardness of water and are related to $\mathrm{pH}$. Turbidity is a measure of the suspended solids in the water.

\section{Inorganic Constituents}

Inorganic constituents are mostly naturally present in groundwater. Groundwater samples were analyzed for the following inorganic constituent classes: major and minor ions, nutrients and dissolved organic carbon, and trace elements (including metals; tables 4-6).

Nutrients include nitrogen and phosphorus compounds and dissolved organic carbon. Data for ammonia, nitrite plus nitrate, nitrite, total nitrogen, and phosphorus measured as orthophosphate are presented in table 4. Nutrients are present naturally, but nutrient concentrations also are affected by human activities such as farming and wastewater disposal. Nitrogen was measured as total nitrogen and as the individual nitrogen species of nitrite, nitrate, and ammonia. Nutrient concentrations can affect the quality of groundwater for use as drinking water. 
Major and minor ions are cations and anions that can be dissolved in water from geologic materials. Concentrations of major and minor ions can be used to classify water into different types (Hem, 1992; Hiscock, 2005). Waters with similar ion concentrations often have similar history, recharge areas, climate, mineralogy, and residence time (Güler and others, 2002). Some major ions can affect the quality of water for drinking and other uses. Groundwater samples were analyzed for 10 major and minor ions and total dissolved solids (table 5).

Trace elements consist of metals that are usually present in the environment in very small quantities. Trace elements often are dissolved in water from geologic materials, but concentrations of these elements also can be affected human activities such as mining. Many trace elements can affect the quality of groundwater for use as drinking water. Groundwater samples were analyzed for 22 trace elements (table 6).

\section{Organic Compounds}

Organic compounds are man-made chemicals and include VOCs and pesticides. The VOCs are in disinfectant, solvent, paint, fumigant, asphalt, and fuel additives, to name a few, and have a tendency to evaporate into the air. Pesticides are chemical compounds used to control plant or insect pests and include fungicides, herbicides, and insecticides. Many VOCs and pesticides, if present, can affect the quality of groundwater used for drinking water. Groundwater samples from 2012 were analyzed for 85 VOCs (table 7) and 137 pesticides (table 9). Samples from 2013 were analyzed for 90 VOCs (table 8) and 227 pesticides (table 10). The VOCs and pesticides in samples collected during 2012 (tables 7 and 9) were analyzed using older analytical methods that were replaced by newer methods in 2013 (tables 8 and 10). Some of the VOCs and pesticides from the 2012 schedules are the same as on the 2013 schedules but not all of them. Altogether, the 2012 and 2013 samples were analyzed for 136 unique VOCs and 285 pesticide compounds.

\section{Radiochemistry}

Radiochemical constituents include radionuclides and measurements of radioactivity. Radionuclides are chemical constituents that are produced naturally by the decay of radioactive parent elements such as uranium and thorium. Most radionuclides in groundwater are from geologic sources in rocks and soils. Radionuclides and measurements of radioactivity included in this report are alpha radioactivity, beta radioactivity, radon (a dissolved gas), several isotopes of radium (radium-224, radium-226, and radium-228), polonium-210, and lead-210 (table 11). Uranium also is a radionuclide but typically is measured in units of mass concentration units rather than as units of radioactive activity; because of this, uranium is included with trace elements. In total, groundwater samples were analyzed for eight radionuclides and measures of radioactivity.

\section{Summary}

As part of the third decadal cycle of the U.S. Geological Survey National Water-Quality Assessment (NAWQA) Project, groundwater-quality data are being collected from well networks to assess water-quality conditions in the Nation's principal aquifers and investigate changes in groundwaterquality conditions in selected land use and hydrogeologic settings. Groundwater-quality data are published in annual data series reports, of which this report is the first in the series.

During the period May 2012 through December 2013, 748 wells were sampled. Groundwater quality data were collected from four types of well networks: principal aquifer study networks, land use study networks, major aquifer study networks, and enhanced trends networks. Within principal aquifer, land use, and major aquifer study networks, wells were selected for sampling using a stratified random sampling design: study areas were divided into equal-area grids for well selection. The number of wells in principal aquifer networks ranged from about 60 to 120 wells per network or aquifer for the studies included in this report. About 30 wells typically made up each land use or major aquifer study network. Enhanced trends networks consisted of a small number (two to four) of wells that were selected at locations within aquifers where temporal changes in groundwater quality might be expected.

Groundwater samples were analyzed for water-quality indicators and constituents, including nutrients, major and minor ions, trace elements, volatile organic compounds, pesticides, and radiochemistry. These groundwater quality data are tabulated in this report. Quality-control samples were collected along with environmental samples, and data from blank and replicate quality-control samples also are included in this report.

\section{Acknowledgments}

Many people in addition to the authors participated in providing information for this report. Bryant Jurgens and Tyler Johnson provided tools for data compilation. Personnel in U.S. Geological Survey water science centers, too numerous to name individually, collected, packaged, and shipped water samples to the laboratories for analysis and ensured results were entered into the U.S. Geological Survey National Water Information System. 


\section{References Cited}

Anning, D.W., and Konieczki, A.D., 2005, Classification of hydrogeologic areas and hydrogeologic flow systems in the Basin and Range physiographic province, southwestern United States: U.S. Geological Survey Professional Paper 1702, 37 p., 2 pl., accessed January 4, 2016, at http://pubs. usgs.gov/pp/2005/pp1702/.

Arnold, T.L., Warner, K.L., Groschen, G.E., Caldwell, J.P., and Kalkoff, S.J., 2008, Hydrochemical regions of the glacial aquifer system, northern United States, and their environmental and water-quality characteristics: U.S. Geological Survey Scientific Investigations Report 2008-5015, 83 p., accessed January 4, 2016, at http://pubs.usgs.gov/sir/2008/5015/.

Ator, S.W., Denver, J.M., Krantz, D.E., Newell, W.L., and Martucci, S.K., 2005, A surficial hydrogeologic framework for the Mid-Atlantic coastal plain: U.S. Geological Survey Professional Paper 1680, accessed January 4, 2016, at http://pubs.er.usgs.gov/publication/pp1680.

Barlow, J.R.B., Kingsbury, J.A., and Coupe, R.H., 2012, Changes in shallow groundwater quality beneath recently urbanized areas in the Memphis, Tennessee area: Journal of the American Water Resources Association, vol. 48, no. 2, p. 336-354. [Also available at http://dx.doi.org/10.1111/ j.1752-1688.2011.00616.x.]

Belitz, Kenneth; Jurgens, Bryant; Landon, M. K., Fram, M. S., and Johnson, Tyler, 2010, Estimation of aquifer scale proportion using equal area grids-Assessment of regional scale groundwater quality: Water Resources Research, v. 46 , no. 11,14 p. [Also available at http://dx.doi. org/10.1029/2010WR009321.]

Berndt, M.P., and Crandall, C.A., 2009, Factors affecting water quality in domestic wells in the Upper Floridan aquifer, southeastern United States, 1998-2005: U.S. Geological Survey Scientific Investigations Report 2009-5147, 39 p., accessed January 4, 2016, at http://pubs.usgs.gov/ sir/2009/5147/.

Berndt, M.P., Hatzell, H.H., Crandall, C.A., Turtora, Michael, Pittman, J.R., and Oaksford, E.T., 1998, Water quality in the Georgia-Florida coastal plain, Georgia and Florida, 1992-96: U.S. Geological Survey Circular 1151, accessed January 4, 2016, at http://pubs.usgs.gov/circ/circ1151/.

Berndt, M.P., Katz, B.G., Kingsbury, J.A., and Crandall, C.A., 2014, The quality of our Nation's waters-Water quality in the Upper Floridan aquifer and overlying surficial aquifers, southeastern United States, 1993-2010: U.S. Geological Survey Circular 1355, 72 p., accessed January 4, 2016, at http://pubs.usgs.gov/circ/1355/.
Bevans, H.E., Lico, M.S., and Lawrence, S.J., 1998, Water quality in the Las Vegas Valley area and the Carson and Truckee River Basins, Nevada and California, 1992-96: U.S. Geological Survey Circular 1170, 47 p., accessed January 4, 2016, at http://pubs.usgs.gov/circ/circ1170/.

Bonn, B.A., 2008, Using the U.S. Geological Survey National Water-Quality Laboratory LT-MDL to evaluate and analyze date: U.S. Geological Survey Open-File Report 2008-1227, 73 p., accessed January 4, 2016, at http://pubs.usgs.gov/ of/2008/1227/.

Brenton, R.W., and Arnett, T.L., 1993, Methods of analysis by the U.S. Geological Survey National Water Quality Laboratory-Determination of dissolved organic carbon by UVpromoted persulfate oxidation and infrared spectrometry: U.S. Geological Survey Open-File Report 92-480, 12 p., accessed January 4, 2016, at http://pubs.er.usgs.gov/publication/ofr92480.

Bruce, B.B., and McMahon, P.B., 1998, Shallow ground-water quality of selected land-use/aquifer settings in the South Platte River Basin, Colorado and Nebraska, 1993-95: U.S. Geological Survey Water-Resources Investigations Report 97-4229, 48 p., accessed January 4, 2016, at http://pubs. er.usgs.gov/publication/wri974229.

Burow, K.R., and Belitz, Kenneth, 2014, Groundwater studies-Principal aquifer surveys: U.S. Geological Survey Fact Sheet 2014-3024, 2p., accessed January 4, 2016, at http://pubs.usgs.gov/fs/2014/3024/.

Burow, K.R., Dubrovsky, N.M., and Shelton, J.L., 2007, Temporal trends in concentrations of DBCP and nitrate in groundwater in the eastern San Joaquin Valley, California, USA: Hydrogeology Journal, v. 15, no. 5, p. 991-1007, accessed January 4, 2016, at http://dx.doi.org/10.1007/ s10040-006-0148-7.

Burow, K.R., Panshin, S.Y., Dubrovsky, N.M., VanBrocklin, D., and Fogg, G.E., 1999, Evaluation of processes affecting 1,2-dibromo-3-chloropropane (DBCP) concentrations in ground water in the eastern San Joaquin Valley, California-Analysis of chemical data and ground-water flow and transport simulations: U.S. Geological Survey WaterResources Investigations Report 99-4059, 57 p., accessed January 4, 2016, at http://pubs.er.usgs.gov/publication/ wri994059.

Burow, K.R., Shelton, J.L., and Dubrovsky, N.M., 1998, Occurrence of nitrate and pesticides in ground water beneath three agricultural land-use settings in the eastern San Joaquin Valley, California, 1993-1995: U.S. Geological Survey Water-Resources Investigations Reports 97-4284, 51 p., accessed January 4, 2016, at http://pubs.er.usgs.gov/ publication/wri974284. 
Burow, K.R., Weissmann, G.S., Miller, R.D., Placzek, Gary, 1997, Hydrogeologic facies characterization of an alluvial fan near Fresno, California, using geophysical techniques: U.S. Geological Survey Open-File Report 97-46, 15 p., accessed January 4, 2016, at http://pubs.usgs.gov/of/1997/0046/report.pdf.

Burton, C.A., and Belitz, Kenneth, 2008, Ground-water quality data in the southeast San Joaquin Valley, 20052006-Results from the California GAMA Program: U.S. Geological Survey Data Series 351, 103 p., accessed January 4, 2016, at http://pubs.usgs.gov/ds/351/.

Bush, P.W., Ardis, A.F., Fahlquist, Lynne, Ging, P.B., Hornig, C.E., and Lanning-Rush, J.L., 2000, Water quality in south-central Texas, Texas, 1996-98: U.S. Geological Survey Circular 1212, 32 p., accessed January 4, 2016, at http://pubs.usgs.gov/circ/circ1212/.

California State Water Resources Control Board, 2015, Geotracker GAMA: State of California, State Water Resources Control Board database, accessed February 10, 2015, at http://geotracker.waterboards.ca.gov/gama/.

Childress, C.J.O., Forman, W.T., Connor, B.F., and Maloney, T.J., 1999, New reporting procedures based on long-term method detection levels and some considerations for interpretations of water-quality data provided by the U.S. Geological Survey National Water Quality Laboratory: U.S. Geological Survey Open-File Report 99-193, 19 p., accessed January 4, 2016, at http://water.usgs.gov/owq/ OFR_99-193/index.html.

City of Fresno, 2015, Groundwater + surface water: City of Fresno Water Division, accessed February 9, 2015, at http://www.fresno.gov/Government/DepartmentDirectory/ PublicUtilities/Watermanagement/watersource/gwsw.htm.

Clark, B.R., and Hart, R.M., 2009, The Mississippi Embayment Regional Aquifer Study (MERAS) - Documentation of a groundwater-flow model constructed to assess water availability in the Mississippi embayment: U.S. Geological Survey Scientific Investigations Report 2009-5172, 62 p., accessed January 4, 2016, at http://pubs.usgs.gov/ $\operatorname{sir} / 2009 / 5172 /$.

Clesceri, L.S., Greenberg, A.E., and Eaton, A.D., 1998, Standard methods for the examination of water and wastewater (20th ed.): Washington, D.C., American Public Health Association, American Water Works Association, and Water Environment Federation, p 3-37 to 3-43.

Covay, K.J., and Bevans, H.E., 1997, Data on ground-water quality, Reno-Sparks area, Nevada, 1994 and 1995: U.S. Geological Survey Open-File Report 97-222, 1 plate, accessed January 4, 2016, at http://pubs.usgs.gov/ of/1997/0222/plate-1.pdf.
Cushing, E.M., Boswell, E.H., and Hosman, R.L., 1964, General geology of the Mississippi embayment: U.S. Geological Survey Professional Paper 448-B, 28 p.

Debrewer, L.M., Ator, S.W., and Denver, J.M., 2005, Factors affecting spatial and temporal variability in nutrient and pesticide concentrations in the surficial aquifer on the Delmarva Peninsula: U.S. Geological Survey Scientific Investigations Report 2005-5257, accessed January 4, 2016, at http://pubs.usgs.gov/sir/2005/5257/.

Dennehy, K.F., Litke, D.W., Tate, C.M., Qi, S.L., McMahon, P.B., Bruce, B.W., Kimbrough, R.A., and Heiny, J.S., 1998, Water quality in the South Platte River Basin, Colorado, Nebraska, and Wyoming, 1992-95: U.S. Geological Survey Circular 1167, 38 p., accessed January 4, 2016, at http://pubs.usgs.gov/circ/circ1167/.

Denver, J.M., Ator, S.W., Debrewer, L.M., Ferrari, M.J., Barbaro, J.R., Hancock, T.C., Brayton, M.J., and Nardi, M.R., 2004, Water quality in the Delmarva Peninsula, 1999-2001: U.S. Geological Survey Circular 1228, 30 p., accessed January 4, 2016, at http://pubs.usgs.gov/circ/2004/1228/.

Denver, J.M., Ator, S.W., Fischer, J.M., Harned, D.C., Schubert, Christopher, and Szabo, Zoltan, 2014, The quality of our Nation's waters-Water quality in the Northern Atlantic Coastal Plain surficial aquifer system, Delaware, Maryland, New Jersey, New York, North Carolina, and Virginia, 1988-2009: U.S. Geological Survey Circular 1353, 88 p., accessed January 4, 2016, at http://dx.doi. org/10.3133/cir1353.

DePaul, V.T., Rice, D.E., and Zapecza, O.S., 2008, Water-level changes in aquifers of the Atlantic Coastal Plain, predevelopment to 2000: U.S. Geological Survey Scientific Investigations Report 2007-5247, 88 p., accessed January 4, 2016, at http://pubs.usgs.gov/sir/2007/5247/.

DeSimone, L.A., McMahon, P.B., and Rosen, M.R., 2014, The quality of our Nation's waters-Water quality in Principal Aquifers of the United States, 1991-2010: U.S. Geological Survey Circular 1360, 151 p., http://dx.doi.org/10.3133/ cir1360.

Dubrovsky, N.M., Burow, K.R., Clark, G.M., Gronberg, J.M., Hamilton P.A., Hitt, K.J., Mueller, D.K., Munn, M.D., Nolan, B.T., Puckett, L.J., Rupert, M.G., Short, T.M., Spahr, N.E., Sprague, L.A., and Wilber, W.G., 2010, The quality of our Nation's waters-Nutrients in the Nation's streams and groundwater, 1992-2004: U.S. Geological Survey Circular 1350, 174 p., accessed January 4, 2016, at http://pubs.usgs. gov/circ/1350/.

Dubrovsky, N.M., Kratzer, C.R., Brown, L.R., Gronberg, J.M., and Burow, K.R., 1998, Water quality in the San JoaquinTulare Basins, California, 1992-95: U.S. Geological Survey Circular 1159, 38 p., accessed January 4, 2016, at http:// pubs.usgs.gov/circ/circ1159/. 
Fishman, M.J., ed., 1993, Methods of analysis by the U.S. Geological Survey National Water Quality LaboratoryDetermination of inorganic and organic constituents in water and fluvial sediments: U.S. Geological Survey OpenFile Report 93-125, 217 p., accessed January 4, 2016, at http://pubs.er.usgs.gov/publication/ofr93125.

Fishman, M.J., and Friedman, L.C., 1989, Methods for determination of inorganic substances in water and fluvial sediments: U.S. Geological Survey Techniques of Water-Resources Investigations, book 5, chap. A1, 545 p., accessed January 4, 2016, at http://pubs.usgs.gov/twri/ twri5-a1/.

Frick. E.A., Hippe, D.J., Buell, G.R., Couch, C.A., Hopkins, E.H., Wangsness, D.J., and Garrett, J.W., 1998, Water quality in the Apalachicola-Chattahoochee-Flint River Basin, Georgia, Alabama, and Florida 1992-95: U.S. Geological Survey Circular 1164, 38 p., accessed January 4, 2016, at http://pubs.usgs.gov/circ/circ1164/.

Furlong, E.T., Anderson, B.D., Werner, S.L., Soliven, P.P., Coffey, L.J., and Burkhardt, M.R., 2001, Methods of analysis by the U.S. Geological Survey National Water Quality Laboratory-Determination of pesticides in water by graphitized carbon-based solid-phase extraction and high-performance liquid chromatography/mass spectrometry: U.S. Geological Survey Water-Resources Investigations Report 01-4134, 73 p., accessed January 4, 2016, at http:// nwql.usgs.gov/rpt.shtml?WRIR-01-4134.

Garbarino, J.R., 1999, Methods of analysis by the U.S. Geological Survey National Water Quality LaboratoryDetermination of dissolved arsenic, boron, lithium, selenium, strontium, thallium, and vanadium using inductively coupled plasma-mass spectrometry: U.S. Geological Survey Open-File Report 99-093, 31 p., accessed January 4, 2016, at http://pubs.er.usgs.gov/publication/ofr9993.

Garbarino, J.R., Kanagy, L.K., and Cree, M.E., 2005, Determination of elements in natural-water, biota, sediment and soil samples using collision/reaction cell inductively coupled plasma-mass spectrometry: U.S. Geological Survey Techniques and Methods, book 5, chap. 1, sec. B, 88 p., accessed January 4, 2016, at http://pubs.usgs.gov/tm/2006/tm5b1/.

Gilliom, R.J., Alley, W.M. and Gurtz, M.E., 1995, Design of the National Water-Quality Assessment Program: occurrence and distribution of water-quality conditions, U.S. Geological Survey Circular 1112, 33 p. accessed March 1, 2016, at https://pubs.er.usgs.gov/publication/cir1112
Gilliom, R.J., Barbash, J.E., Crawford, C.G., Hamilton, P.A., Martin, J.D., Nakagaki, Naomi, Nowell, L.H., Scott, J.C., Stackelberg, P.E., Thelin, G.P., and Wolock, D.M., 2006, The quality of our Nation's waters-Pesticides in the Nation's streams and ground water, 1992-2001: U.S. Geological Survey Circular 1291, accessed January 4, 2016, at http://pubs.usgs.gov/circ/2005/1291/.

Gonthier, G.J., 2002, Quality of shallow ground water in recently developed residential and commercial areas, Memphis vicinity, Tennessee, 1997: U.S. Geological Survey Water-Resources Investigations Report 02-4294, 105 p., accessed January 4, 2016, at http://ms.water.usgs.gov/publications/WRIR_02_4294.html.

Graham, D.D., and Parks, W.S., 1986, Potential for leakage among principal aquifers in the Memphis area, Tennessee: U.S. Geological Survey Water-Resources Investigations Report 85-4295, 46 p., accessed January 4, 2016, at http://pubs.usgs.gov/wri/wri85-4295/.

Griffiths, J.F., and Strauss, R.F., 1985, The variety of Texas weather: Weatherwise, v. 38, p. 137-141.

Güler, C., Thyne, G.D., McCray, J.E., and Turner, A.K., 2002, Evaluation of graphical and multivariate statistical methods for classification of water chemistry data: Hydrogeology Journal, v. 10, no. 4, p. 455-474.

Hem, J.D., 1992, Study and interpretation of the chemical characteristics of natural water: U.S. Geological Survey Water-Supply Paper 2254, 264 p.

Hiscock, K.M., 2005, Hydrogeology-Principles and practice: United Kingdom, Blackwell Publishing, 389 p.

Huntington, J.M., 2010a, Conceptual understanding and groundwater quality of the basin-fill aquifer Truckee Meadows, Nevada, sec. 3 of Thiros, S.A., Bexfield, L.M., Anning, D.W., and Huntington, J.M., eds., 2010, Conceptual understanding and groundwater quality of selected basin-fill aquifers in the southwestern United States: U.S. Geological Survey Professional Paper 1781, p. 35-48, accessed January 4, 2016, at http://pubs.usgs.gov/pp/1781/.

Huntington, J.M., 2010b, Conceptual understanding and groundwater quality of the basin-fill aquifers in Eagle and Carson Valleys, Nevada, sec. 4 of Thiros, S.A., Bexfield, L.M., Anning, D.W., and Huntington, J.M., eds., 2010, Conceptual understanding and groundwater quality of selected basin-fill aquifers in the southwestern United States: U.S. Geological Survey Professional Paper 1781, p. 49-69, accessed January 4, 2016, at http://pubs.usgs.gov/pp/1781/. 
Jones, B.D., 1991, Texas_-Floods and droughts, in Paulson, R.W., Chase, E.B., Roberts, R.S., and Moody, D.W., comps., National water summary 1988-89-Hydrologic events and floods and droughts: U.S. Geological Survey Water-Supply Paper 2375, p. 513-520, accessed January 4, 2016, at http://pubs.er.usgs.gov/publication/wsp2375.

Kleiss, B.A., Coupe, R.H., Gonthier, G.J., and Justus, B.J., 2000, Water quality in the Mississippi Embayment, Mississippi, Louisiana, Arkansas, Missouri, Tennessee, and Kentucky,1995-98: U.S. Geological Survey Circular 1208, 36 p., accessed January 4, 2016, at http://pubs.usgs.gov/circ/ circ1208/.

Koterba, M.T., Wilde, F.D., and Lapham, W.W., 1995, Groundwater data-collection protocols and procedures for the National Water-Quality Assessment Program-Collection and documentation of water-quality samples and related data: U.S. Geological Survey Open-File Report 95-399, 113 p., accessed January 4, 2016, at http://pubs.usgs.gov/ of/1995/ofr-95-399/.

Lapham, W.W., Wilde, F.D., and Koterba, M.T., 1995, Ground-water data-collection protocols and procedures for the National Water-Quality Assessment Program-Selection, installation, and documentation of wells, and collection of related data: U.S. Geological Survey Open-File Report 95-398, 71 p., accessed January 4, 2016, at http://pubs.usgs. gov/of/1995/ofr-95-398/.

Larkin, T.J., and Bomar, G.W., 1983, Climatic atlas of Texas: Texas Department of Water Resources, Limited Printing Report LP-192, 151 p.

Lico, M.S., 1998, Quality of ground water beneath urban and agricultural lands in Las Vegas Valley and the Carson and Truckee River Basins, Nevada and California: U.S. Geological Survey Water-Resources Investigations Report 97-4259, 24 p., accessed January 4, 2016, at http://pubs. er.usgs.gov/publication/wri974259.

Long, A.F., 1989, Hydrogeology of the Clayton and Claiborne aquifer systems: Atlanta, Ga., Georgia Department of Natural Resources, Environmental Protection Division, Georgia Geologic Survey, Hydrologic Atlas 19, accessed February 11, 2015, at https://epd.georgia.gov/sites/epd.georgia.gov/ files/related_files/site_page/HA-19.pdf.

Madsen, J.E., Sandstrom, M.W., and Zaugg, S.D., 2003, Methods of analysis by the U.S. Geological Survey National Water Quality Laboratory_A method supplement for the determination of fipronil and degradates in water by gas chromatography/mass spectrometry: U.S. Geological Survey Open-File Report 02-462, 11 p., accessed January 4, 2016, at http://pubs.er.usgs.gov/publication/ofr02462.
Mahler, B.J., Garner, B.D., Musgrove, MaryLynn, Guilfoyle, A.L., and Rao, M.V., 2006, Recent (2003-05) water quality of Barton Springs, Austin, Texas, with emphasis on factors affecting variability: U.S. Geological Survey Scientific Investigations Report 2006-5299, 83 p., 5 appendixes, accessed January 4, 2016, at http://pubs.usgs.gov/ $\operatorname{sir} / 2006 / 5299 /$

Marchand, D.E., and Allwardt, Alan, 1981, Late Cenozoic stratigraphic units, northeastern San Joaquin Valley, California: U.S. Geological Survey Bulletin 1470, 77 p., accessed January 4, 2016, at http://pubs.usgs.gov/bul/1470/report.pdf.

Masterson, J.P., Pope, J.P., Monti, Jack, Jr., Nardi, M.R., Finkelstein, J.S., and McCoy, K.J., 2013, Hydrogeology and hydrologic conditions of the Northern Atlantic Coastal Plain aquifer system from Long Island, New York, to North Carolina: U.S. Geological Survey Scientific Investigations Report 2013-5133, accessed January 4, 2016, at http:// dx.doi.org/10.3133/sir20135133.

Masterson, J.P., Pope, J.P., Monti, Jack, Jr., Nardi, M.R., Finkelstein, J.S., and McCoy, K.J., 2015, Hydrogeology and hydrologic conditions of the Northern Atlantic Coastal Plain aquifer system from Long Island, New York, to North Carolina (ver. 1.1, September 2015): U.S. Geological Survey Scientific Investigations Report 2013-5133, 76 p., accessed January 4, 2016, at http://dx.doi.org/10.3133/sir20135133.

Maupin, M.A., and Arnold, T.L., 2010, Estimates for selfsupplied domestic withdrawals and population served for selected principal aquifers, calendar year 2005: U.S. Geological Survey Open-File Report 2010-1223, 10 p., accessed January 4, 2016, at http://pubs.usgs.gov/ of/2010/1223/.

Maupin, M.A., and Barber, N.L., 2005, Estimated withdrawals from principal aquifers in the United States, 2000: U.S. Geological Survey Circular 1279, 46 p., accessed January 4, 2016, at http://pubs.usgs.gov/circ/2005/1279/.

Metz, P.A., Delzer, G.C., Berndt, M.P., Crandall, C.A., and Toccalino, P.L., 2007, Anthropogenic organic compounds in ground water and finished water of community water systems in the northern Tampa Bay area, Florida, 2002-04: U.S. Geological Survey Scientific Investigations Report 2006-5267, 48 p., accessed January 4, 2016, at http://pubs. usgs.gov/sir/2006/5267/.

McCurdy, D.E., Garbarino, J.R., and Mullin, A.H., 2008, Interpreting and reporting radiological water-quality data: U.S. Geological Survey Techniques and Methods, book 5, chap. B6, 33 p., accessed January 4, 2016, at http://pubs. usgs.gov/tm/05b06/.

Miller, J.A., 1990, Ground water atlas of the United StatesAlabama, Florida, Georgia, South Carolina: U.S. Geological Survey Hydrologic Atlas 730-G, accessed January 4, 2016, at http://pubs.usgs.gov/ha/ha730/ch_g/index.html. 
Moran, M.J., Zogorski, J.S., and Rowe, B.L., 2006, Approach to an assessment of volatile organic compounds in the Nation's ground water and drinking-water supply wells: U.S. Geological Survey Open-File Report 2005-1452, accessed January 4, 2016, at http://pubs.usgs.gov/ of/2005/1452.

Musgrove, MaryLynn, Fahlquist, Lynne, Houston, N.A., Lindgren, R.J., and Ging, P.B., 2010, Geochemical evolution processes and water-quality observations based on results of the National Water-Quality Assessment Program in the San Antonio segment of the Edwards aquifer, Texas, 1996-2006: U.S. Geological Survey Scientific Investigations Report 2010-5129, 93 p., accessed January 4, 2016, at http://pubs.usgs.gov/sir/2010/5129/.

Musgrove, MaryLynn, Fahlquist, Lynne, Stanton, G.P., Houston, N.A., and Lindgren, R.J., 2011, Hydrogeology, chemical characteristics, and water sources and pathways in the zone of contribution of a public-supply well in San Antonio, Texas: U.S. Geological Survey Scientific Investigations Report 2011-5146, 194 p., accessed January 4, 2016, at http://pubs.usgs.gov/sir/2011/5146/.

National Oceanic and Atmospheric Administration, 2014a, National Weather Service forecast office-Austin/San Antonio, TX-Unique local climate data: National Weather Service, Austin/San Antonio, Texas, Weather Forecast Office Web site, accessed April 11, 2014, at http://www.nws.noaa. gov/climate/local_data.php?wfo=ewx.

National Oceanic and Atmospheric Administration, 2014b, Data tools-1981-2010 normals: National Oceanic and Atmospheric Administration, National Centers for Environmental Information Web site, accessed August 28, 2014, at http://www.ncdc.noaa.gov/cdo-web/datatools/normals.

Olcott, P.G., 1992, Ground water atlas of the United StatesIowa, Michigan, Minnesota, Wisconsin: U.S. Geological Survey Hydrologic Atlas 730-J, accessed January 4, 2016, at http://pubs.usgs.gov/ha/ha730/ch_j/index.html.

Olcott, P.G., 1995, Ground water atlas of the United StatesConnecticut, Maine, Massachusetts, New Hampshire, New York, Rhode Island, Vermont: U.S. Geological Survey Hydrologic Atlas 730-M, accessed January 4, 2016, at http://pubs.usgs.gov/ha/ha730/ch_m/index.html.

Parks, W.S., 1990, Hydrogeology and preliminary assessment of the potential for contamination of the Memphis aquifer in the Memphis area, Tennessee: U.S. Geological Survey Water-Resources Investigations Report 90-4092, 39 p., accessed January 4, 2016, at http://pubs.usgs.gov/wri/ wri904092/.
Parks, W.S., Mirecki, J.E., and Kingsbury, J.A., 1995, Hydrogeology, ground-water quality, and source of ground water causing water-quality changes in the Davis well field at Memphis, Tennessee: USGS Water Resources Investigations Report 94-4212, 58 p.

Paschke, S.S., ed., 2011, Groundwater availability of the Denver Basin aquifer system, Colorado: U.S. Geological Survey Professional Paper 1770, 274 p., accessed January 4, 2016, at http://pubs.usgs.gov/pp/1770/.

Paschke, S.S., Schaffrath, K.R., and Mashburn, S.L., 2008, Near-decadal changes in nitrate and pesticide concentrations in the South Platte River alluvial aquifer: Journal of Environmental Quality, v. 37, p. S-281-S-295.

Patton, C.J., and Kryskalla. J.R., 2003, Methods of analysis by the U.S. Geological Survey National Water Quality Laboratory-Evaluation of alkaline persulfate digestion as an alternative to Kjeldahl digestion for determination of total and dissolved nitrogen and phosphorus in water: Water-Resources Investigations Report 03-4174, 33 p., accessed January 4, 2016, at http://nwql.usgs.gov/WRIR03-4174.shtml.

Patton, C.J., and Kryskalla, J. R., 2011, Colorimetric determination of nitrate plus nitrite in water by enzymatic reduction, automated discrete analyzer methods: U.S. Geological Survey Techniques and Methods, book 5, chap. B8, 34 p., accessed January 4, 2016, at http://pubs.usgs.gov/ $\mathrm{tm} / 05 \mathrm{~b} 08 /$.

Peters, C.A., Robertson, D.M., Saad, D.A., Sullivan, D.J., Scudder, B.C., Fitzpatrick, F.A., Richards, K.D., Stewart, J.S., Fitzgerald, S.A., and Lenz, B.N., 1998, Water quality in the western Lake Michigan drainages, 1992-95: U.S. Geological Survey Circular 1156, 40 p., accessed January 4, 2016, at http://pubs.usgs.gov/circ/circ1156/.

Planert, Michael, and Williams, J.S., 1995, Ground water atlas of the United States - California, Nevada: U.S. Geological Survey Hydrologic Atlas 730-B, accessed January 4, 2016, at http://pubs.usgs.gov/ha/ha730/ch_b/index.html.

Renken, R.A., 1984, The hydrogeologic framework for the southeastern coastal plain aquifer system of the United States: U.S. Geological Survey Water-Resources Investigations Report 84-4243, 26 p., accessed January 4, 2016, at http://pubs.er.usgs.gov/publication/wri844243.

Renken, R.A., 1998, Ground water atlas of the United StatesArkansas, Louisiana, Mississippi: U.S. Geological Survey Hydrologic Atlas 730-F, accessed January 4, 2016, at http://pubs.usgs.gov/ha/ha730/ch_f/index.html. 
Robson, S.G., and Banta, E.R., 1995, Ground water atlas of the United States-Arizona, Colorado, New Mexico, Utah: U.S. Geological Survey Hydrologic Atlas 730-C, accessed January 4, 2016, at http://pubs.usgs.gov/ha/ha730/ch_c/ index.html.

Rose, D.L., Sandstrom, M.W., and Murtagh, L.K., 2016, Determination of heat purgeable and ambient purgeable volatile organic compounds in water by gas chromatography/mass spectrometry: U.S. Geological Survey Techniques and Methods, book 5, chap. B12, 62 p.

Rowe, G.L., Jr., Belitz, Kenneth, Essaid, H.I., Gilliom, R.J., Hamilton, P.A., Hoos, A.B., Lynch, D.D., Munn, M.D., and Wolock, D.W., 2010, Design of cycle 3 of the National Water-Quality Assessment Program, 2013-2023 —Part 1 -Framework of water-quality issues and potential approaches: U.S. Geological Survey Open-File Report 2009-1296, 54 p., accessed January 4, 2016, at http://pubs. usgs.gov/of/2009/1296/.

Rowe, G.L., Belitz, Kenneth, Demas, C.R., Essaid, H.I., Gilliom, R.J., Hamilton, P.A., Hoos, A.B., Lee, C.J., Munn, M.D., and Wolock, D.W., 2013, Design of cycle 3 of the National Water-Quality Assessment Program, 2013-23Part 2-Science plan for improved water-quality information and management: U.S. Geological Survey Open File Report 2013-1160, accessed January 4, 2016, at http://pubs. usgs.gov/of/2013/1160/.

Ryder, P.D., 1996, Ground water atlas of the United StatesOklahoma, Texas: U.S. Geological Survey Hydrologic Atlas 730-E, accessed January 4, 2016, at http://pubs.usgs.gov/ ha/ha730/ch_e/index.html.

Sandstrom, M.W., Kanagy, L.K., Anderson, C.E., and Kanagy, C.J., 2016, Determination of pesticides and pesticide degradates in filtered water by direct aqueous injection liquid chromatography tandem mass spectrometry: U.S. Geological Survey Techniques and Methods book 5, chap. B11, 54 p. [Also available at http://dx.doi.org/10.3133/tm5B11.]

Sandstrom, M.W., Stroppel, M.E., Foreman, W.T., and Schroeder, M.P., 2001, Methods of analysis by the U.S. Geological Survey National Water Quality Laboratory-Determination of moderate-use pesticides and selected degradates in water by $\mathrm{C}-18$ solid-phase extraction and gas chromatography/mass spectrometry: U.S. Geological Survey WaterResources Investigations Report 01-4098, 70 p., accessed January 4, 2016, at http://nwql.usgs.gov/Public/WRIR-014098.shtml.

Sandstrom, M.W., and Wilde, F.D., 2014, Syringe-filter procedure for processing samples for analysis of organic compounds by DAI LC-MS/MS: U.S. Geological Survey Techniques of Water-Resources Investigations, book 9, chap. A5, sec. 5.2.2.B., accessed January 4, 2016, at http:// water.usgs.gov/owq/FieldManual/chapter5/pdf/5.2.2.B.pdf.
Sargent, B.P., Maupin, M.A., and Hinkle, S.R., 2008, Estimated withdrawals from stream-valley aquifers and refined estimated withdrawals from selected aquifers in the United States, 2000: U.S. Geological Survey Scientific Investigations Report 2008-5003, 71 p., accessed January 4, 2016, at http://pubs.usgs.gov/sir/2008/5003/.

Schaefer, D.H., Green, J.M., and Rosen, M.R., 2007, Hydrogeologic settings and ground-water flow simulations of the Eagle Valley and Spanish Springs regional study areas, Nevada, sec. 3 of Paschke, S.S., ed., Hydrogeologic settings and ground-water flow simulations for regional studies of the transport of anthropogenic and natural contaminants to public-supply wells - Studies begun in 2001: U.S. Geological Survey Professional Paper 1737-A, p. 3-13-33, accessed January 4, 2016, at http://pubs.usgs.gov/ $\mathrm{pp} / 2007 / 1737 \mathrm{a} /$.

Scott, J.C., 1990, Computerized stratified random site-selection approaches for design of a ground-water-quality sampling network: U.S. Geological Survey Water-Resources Investigations Report 90-4101, 109 p., accessed January 4, 2016, at http://pubs.er.usgs.gov/publication/wri904101.

Sharp, J.M., Jr., and Banner, J.L., 1997, The Edwards aquifer-A resource in conflict: Boulder, Colo., The Geological Society of America, Inc., GSA Today, v. 7, no. 8, p. 1-9.

Thiros, S.A., 2010, Conceptual understanding and groundwater quality of the basin-fill aquifer in the Central Valley, California, sec. 13 of Thiros, S.A., Bexfield, L.M., Anning, D.W., and Huntington, J.M., eds., 2010, Conceptual understanding and groundwater quality of selected basin-fill aquifers in the southwestern United States: U.S. Geological Survey Professional Paper 1781, p. 267-287, accessed January 4, 2016, at http://pubs.usgs.gov/pp/1781/.

Thiros, S.A., Paul, A.P., Bexfield, L.M., and Anning, D.W., 2015, The quality of our Nation's waters - Water quality in the basin-fill aquifers of the southwestern United StatesArizona, California, Colorado, Nevada, New Mexico, and Utah, 1993-2009: U.S. Geological Survey Circular 1358, 113 p., accessed January 4, 2016, at http://dx.doi. org/10.3133/cir1358.

Toccalino, P.L., 2007, Development and application of healthbased screening levels for use in water-quality assessments: U.S. Geological Survey Scientific Investigations Report 2007-5106, 12 p., accessed January 4, 2016, at http://pubs. usgs.gov/sir/2007/5106/.

Toccalino, P.L., Norman, J.E., and Schoephoester, K.M., 2014, Health-based screening levels for evaluating water-quality data: U.S. Geological Survey, January 4, 2016, at http://dx.doi.org/10.5066/F71C1TWP. 
Trapp, Henry, Jr., and Horn, M.A., 1997, Ground water atlas of the United States-Delaware, Maryland, New Jersey, North Carolina, Pennsylvania, Virginia, and West Virginia: U.S. Geological Survey Hydrologic Atlas 730-L, accessed January 4, 2016, at http://pubs.usgs.gov/ha/ha730/ch_1/ index.html.

U.S. Environmental Protection Agency, 2004, Multi-agency radiological laboratory analytical protocols manual (MARLAP) — Part II - Chapters 18-20, appendix G (volume III): U.S. Environmental Protection Agency, EPA 402-B-04001C, accessed May 19, 2015, at http://nepis.epa.gov/Exe/ ZyPDF.cgi/P10094KI.PDF?Dockey=P10094KI.PDF.

U.S. Environmental Protection Agency, 2012, Human health benchmarks for pesticides: U.S. Environmental Protection Agency, EPA 822-F-12-001, accessed May 19, 2015, at http://nepis.epa.gov/Exe/ZyPDF.cgi/P100E60P. PDF?Dockey=P100E60P.PDF.

U.S. Environmental Protection Agency, 2013, Human health benchmarks for pesticides-Updated 2013 technical document: U.S. Environmental Protection Agency, EPA 820R-13-010, accessed May 19, 2015, at http://nepis.epa.gov/ Exe/ZyPDF.cgi/P100GRDJ.PDF?Dockey=P100GRDJ.PDF.

U.S. Environmental Protection Agency, 2015, Definition and procedure for the determination of the method detection limit—revision 1.11: U.S. Code of Federal Regulations, Title 40, v. 24, pt. 136, app. B, accessed May 14, 2015, at http://www.gpo.gov/fdsys/pkg/CFR-2012-title40-vol24/pdf/ CFR-2012-title40-vol24-part136-appB.pdf.

U.S. Geological Survey, 2003, Principal aquifers of the 48 conterminous United States, Hawaii, Puerto Rico, and the U.S. Virgin Islands: U.S. Geological Survey, accessed January 4, 2016, at http://water.usgs.gov/GIS/metadata/usgswrd/ XML/aquifers_us.Xml.

U.S. Geological Survey, 2012, National Water Information System data available on the World Wide Web (USGS Water Data for the Nation), accessed April 21, 2016, at http://nwis.waterdata.usgs.gov/.

U.S. Geological Survey, variously dated, National field manual for the collection of water-quality data: U.S. Geological Survey Techniques of Water-Resources Investigations, book 9, chaps. A1-A9, accessed January 4, 2016, at http://pubs. water.usgs.gov/twri9A.

University of California, 2012, Addressing nitrate in California's drinking water: Center for Watershed Sciences, University of California, Davis, Groundwater Nitrate Project, Implementation of Senate Bill X2 1, accessed February 9, 2015, at http://groundwaternitrate.ucdavis.edu/ files/138956.pdf.
Wagner, R.J., Boulger, R.W., Jr., Oblinger, C.J., and Smith, B.A., 2006, Guidelines and standard procedures for continuous water-quality monitors - Station operation, record computation, and data reporting: U.S. Geological Survey Techniques and Methods 1-D3, 51 p., accessed January 4, 2016, at http://pubs.usgs.gov/tm/2006/tm1D3/.

Warner, K.L., and Ayotte, J.D., 2015, The quality of our Nation's waters-Water quality in the glacial aquifer system, northern United States, 1992-2009: U.S. Geological Survey Circular 1352, 133 p., accessed January 4, 2016, at http://dx.doi.org/10.3133/cir1352.

Weiss, J.S., 1992, Geohydrologic units of the coastal lowlands aquifer system, south-central United States: U.S. Geological Survey Professional Paper 1416-C, 32 p., accessed January 4, 2016, at http://pubs.er.usgs.gov/publication/pp1416C.

Welch, H.L., Kingsbury, J.A., Tollett, R.W., and Seanor, R.C., 2009, Quality of shallow groundwater and drinking water in the Mississippi embayment-Texas coastal uplands aquifer system and the Mississippi River Valley alluvial aquifer, south-central United States, 1994-2004: U.S. Geological Survey Scientific Investigations Report 2009-5091, 51 p., accessed January 4, 2016, at http://pubs.usgs.gov/ sir/2009/5091/.

Western Regional Climate Center, 2015, Fresno Yosemite International Airport, California (043257)—Period of record monthly climate summary: accessed February 5, 2015, at http://www.wrcc.dri.edu/cgi-bin/cliMAIN.pl?ca3257.

Whitehead, R.L., 1996, Ground water atlas of the United States-Montana, North Dakota, South Dakota, Wyoming: U.S. Geological Survey Hydrologic Atlas 730-I, accessed January 4, 2016, at http://pubs.usgs.gov/ha/ha730/ch_i/ index.html.

Wilde, F.D., ed., variously dated, Field measurements: U.S. Geological Survey Techniques of Water-Resources Investigations, book 9, chap. A6, sec. 6.0-6.8, accessed December 22, 2015, at http://pubs.water.usgs.gov/twri9A6/.

Wong, C.I., Mahler, B.J., Musgrove, MaryLynn, and Banner, J.L., 2012, Changes in sources and storage in a karst aquifer during a transition from drought to wet conditions: Journal of Hydrology, v. 468-469, p. 159-172.

Wright, M.T., Belitz, Kenneth, and Johnson, Tyler, 2004, Assessing the susceptibility to contamination of two aquifer systems used for public water supply in the Modesto and Fresno metropolitan areas, California, 2001 and 2002: U.S. Geological Survey Scientific Investigations Report 20045149, 35 p., accessed January 4, 2015, at http://pubs.usgs. gov/sir/2004/5149/. 
Zaugg, S.D., Sandstrom, M.W., Smith, S.G., and Fehlberg, K.M., 1995, Methods of analysis by the U.S. Geological Survey National Water Quality Laboratory-Determination of pesticides in water by $\mathrm{C}-18$ solid-phase extraction and capillary-column gas chromatography/mass spectrometry with selected-ion monitoring: U.S. Geological Survey Open-File Report 95-181, 60 p.
Zogorski, J.S., Carter, J.M., Ivahnenko, Tamara, Lapham, W.W., Moran, M.J., Rowe, B.L., Squillace, P.J., and Toccalino, P.L., 2006, The quality of our Nation's watersVolatile organic compounds in the Nation's groundwater and drinking-water supply wells: U.S. Geological Survey Circular 1292, 101 p., accessed January 4, 2016, at http:// pubs.usgs.gov/circ/circ1292/. 
Appendixes 


\section{Appendix 1. High-Frequency Data from Enhanced Trends Networks}

High frequency data collected at enhanced trends network sites are available from the National Water Information System on-line database (table 1-1). The links in table 1-1 below provide access to the high-frequency data on the Web. Once the Webpage for the site is opened, the user should change the begin and end dates to retrieve the data for the time period May 1, 2012, to December 31, 2013 to access the data for the time period covered by this report.
The enhanced trends network sites may have different equipment installed and may collect different parameters. Additionally, some sites have missing record for various parameters because of equipment failures at various times during the data collection period.

Table 1-1. Web links to data collected at a high frequency from enhanced trends networks.

[See figure 21 of this report for locations of enhanced trends networks. NAWQA, National Water-Quality Assessment]

\begin{tabular}{|c|c|c|}
\hline $\begin{array}{l}\text { Network } \\
\text { name }\end{array}$ & $\begin{array}{l}\text { NAWQA Project well } \\
\text { identification number }\end{array}$ & Link to data collected at a high frequency \\
\hline cvaletn 1 & CVALETN1-01 & http://waterdata.usgs.gov/nwis/uv?site_no=364200119420001 \\
\hline cvaletn1 & CVALETN1-03 & http://waterdata.usgs.gov/nwis/uv?site_no=364200119420003 \\
\hline edtretn 1 & EDTRETN1-01 & http://waterdata.usgs.gov/nwis/uv?site_no=293116098334101 \\
\hline metxetn 1 & METXETN1-01 & http://waterdata.usgs.gov/nwis/uv?site_no=351113089513401 \\
\hline metxetn1 & METXETN1-02 & No high frequency data are available for May 2012_-December 2013. \\
\hline
\end{tabular}

\section{Appendix 2. Water Use in Principal Aquifers}

Table 2-1. Water withdrawals from principal aquifers for public supply and other uses.

[Water withdrawals for public supply, irrigation, and self-supplied industrial use are from Maupin and Barber (2005), adjusted for stream-valley aquifer withdrawals from Sargent and others (2008), for year 2000. Water withdrawals for domestic use are from Maupin and Arnold (2010) for year 2005. Individual uses may not sum to totals because of rounding. Aquifers are listed in order of decreasing withdrawals for public supply. Mgal/d, million gallons per day; nd, not determined]

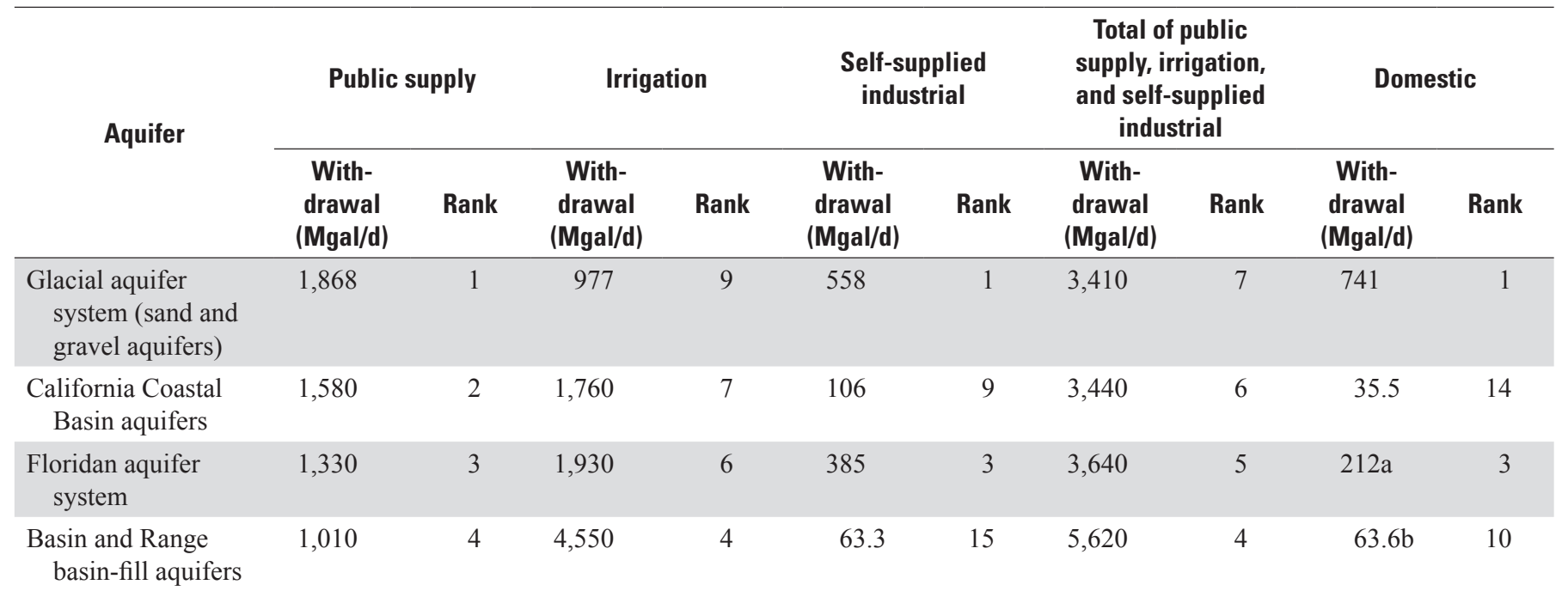


Table 2-1. Water withdrawals from principal aquifers for public supply and other uses. - Continued

[Water withdrawals for public supply, irrigation, and self-supplied industrial use are from Maupin and Barber (2005), adjusted for stream-valley aquifer withdrawals from Sargent and others (2008), for year 2000. Water withdrawals for domestic use are from Maupin and Arnold (2010) for year 2005. Individual uses may not sum to totals because of rounding. Aquifers are listed in order of decreasing withdrawals for public supply. Mgal/d, million gallons per day; nd, not determined]

\begin{tabular}{|c|c|c|c|c|c|c|c|c|c|c|}
\hline Aquifer & \multicolumn{2}{|c|}{ Public supply } & \multicolumn{2}{|c|}{ Irrigation } & \multicolumn{2}{|c|}{$\begin{array}{l}\text { Self-supplied } \\
\text { industrial }\end{array}$} & \multicolumn{2}{|c|}{$\begin{array}{c}\text { Total of public } \\
\text { supply, irrigation, } \\
\text { and self-supplied } \\
\text { industrial }\end{array}$} & \multicolumn{2}{|c|}{ Domestic } \\
\hline $\begin{array}{l}\text { Central Valley } \\
\text { aquifer system }\end{array}$ & 839 & 6 & 8,910 & 3 & 58.9 & 17 & 9,810 & 2 & 136 & 5 \\
\hline $\begin{array}{c}\text { Northern Atlantic } \\
\text { Coastal Plain } \\
\text { aquifer system }\end{array}$ & 793 & 7 & 70.2 & 35 & 172 & 7 & 1,040 & 13 & 140 & 4 \\
\hline $\begin{array}{l}\text { Mississippi } \\
\text { Embayment } \\
\text { aquifer system }\end{array}$ & 576 & 10 & 195 & 26 & 175 & 6 & 946 & 14 & $100 \mathrm{c}$ & 8 \\
\hline $\begin{array}{l}\text { Edwards-Trinity } \\
\text { aquifer system }\end{array}$ & 411 & 11 & 282 & 22 & 47.2 & 20 & 740 & 20 & 63.4 & 11 \\
\hline $\begin{array}{l}\text { Stream Valley } \\
\text { Aquifers }\end{array}$ & 400 & 12 & 984 & 8 & 177 & 5 & 1561 & 10 & nd & nd \\
\hline High Plains aquifer & 389 & 13 & 17,000 & 1 & 99.2 & 10 & 17,500 & 1 & nd & nd \\
\hline Other & 369 & 14 & 615 & 14 & 61.0 & 16 & 1,044 & 12 & & \\
\hline $\begin{array}{l}\text { Southeastern } \\
\text { Coastal Plain } \\
\text { aquifer system }\end{array}$ & 340 & 15 & 382 & 16 & 138 & 8 & 860 & 18 & nd & nd \\
\hline $\begin{array}{l}\text { Rio Grande aquifer } \\
\text { system }\end{array}$ & 240 & 18 & 867 & 11 & 12.2 & 35 & 1,120 & 11 & 18 & 17 \\
\hline $\begin{array}{l}\text { Columbia Plateau } \\
\text { basaltic-rock } \\
\text { aquifers }\end{array}$ & 223 & 19 & 674 & 13 & 35.7 & 24 & 933 & 15 & $33.4 d$ & 16 \\
\hline $\begin{array}{l}\text { Mississippian } \\
\text { aquifers }\end{array}$ & 211 & 20 & 6.31 & 49 & 67.9 & 14 & 286 & 32 & nd & nd \\
\hline $\begin{array}{l}\text { Puget Sound aquifer } \\
\text { system }\end{array}$ & 192 & 21 & 44.9 & 38 & 23.4 & 27 & 260 & 34 & nd & nd \\
\hline $\begin{array}{l}\text { Valley and Ridge } \\
\text { carbonate-rock } \\
\text { aquifers }\end{array}$ & 177 & 22 & 5.65 & 51 & 83.9 & 11 & 267 & 33 & $110 \mathrm{e}$ & 7 \\
\hline $\begin{array}{l}\text { Silurian-Devonian } \\
\text { aquifers }\end{array}$ & 164 & 23 & 27.4 & 41 & 54.7 & 18 & 246 & 35 & nd & nd \\
\hline
\end{tabular}


Table 2-1. Water withdrawals from principal aquifers for public supply and other uses.-Continued

[Water withdrawals for public supply, irrigation, and self-supplied industrial use are from Maupin and Barber (2005), adjusted for stream-valley aquifer withdrawals from Sargent and others (2008), for year 2000. Water withdrawals for domestic use are from Maupin and Arnold (2010) for year 2005. Individual uses may not sum to totals because of rounding. Aquifers are listed in order of decreasing withdrawals for public supply. Mgal/d, million gallons per day; nd, not determined]

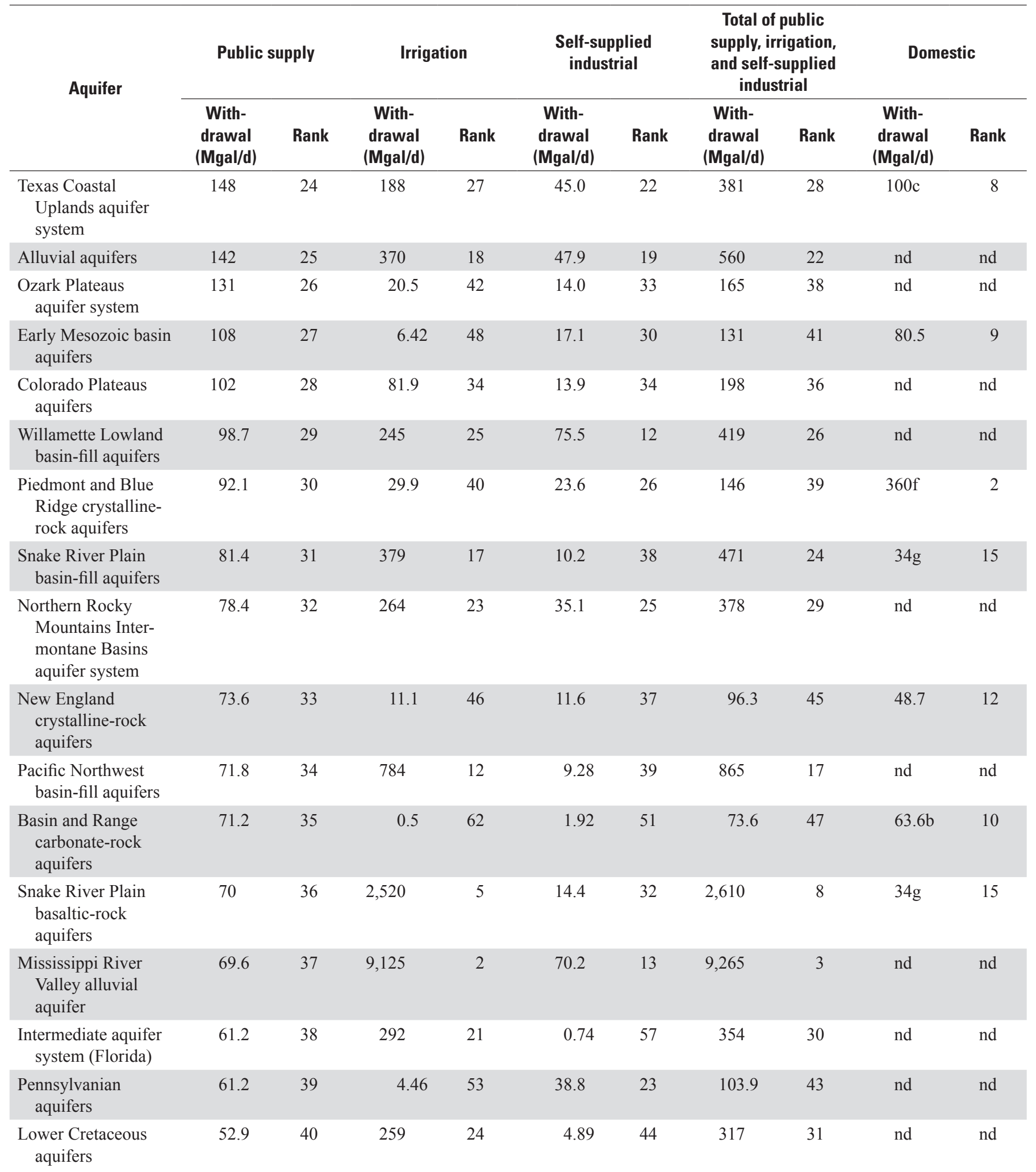


Table 2-1. Water withdrawals from principal aquifers for public supply and other uses._- Continued

[Water withdrawals for public supply, irrigation, and self-supplied industrial use are from Maupin and Barber (2005), adjusted for stream-valley aquifer withdrawals from Sargent and others (2008), for year 2000. Water withdrawals for domestic use are from Maupin and Arnold (2010) for year 2005. Individual uses may not sum to totals because of rounding. Aquifers are listed in order of decreasing withdrawals for public supply. Mgal/d, million gallons per day; nd, not determined]

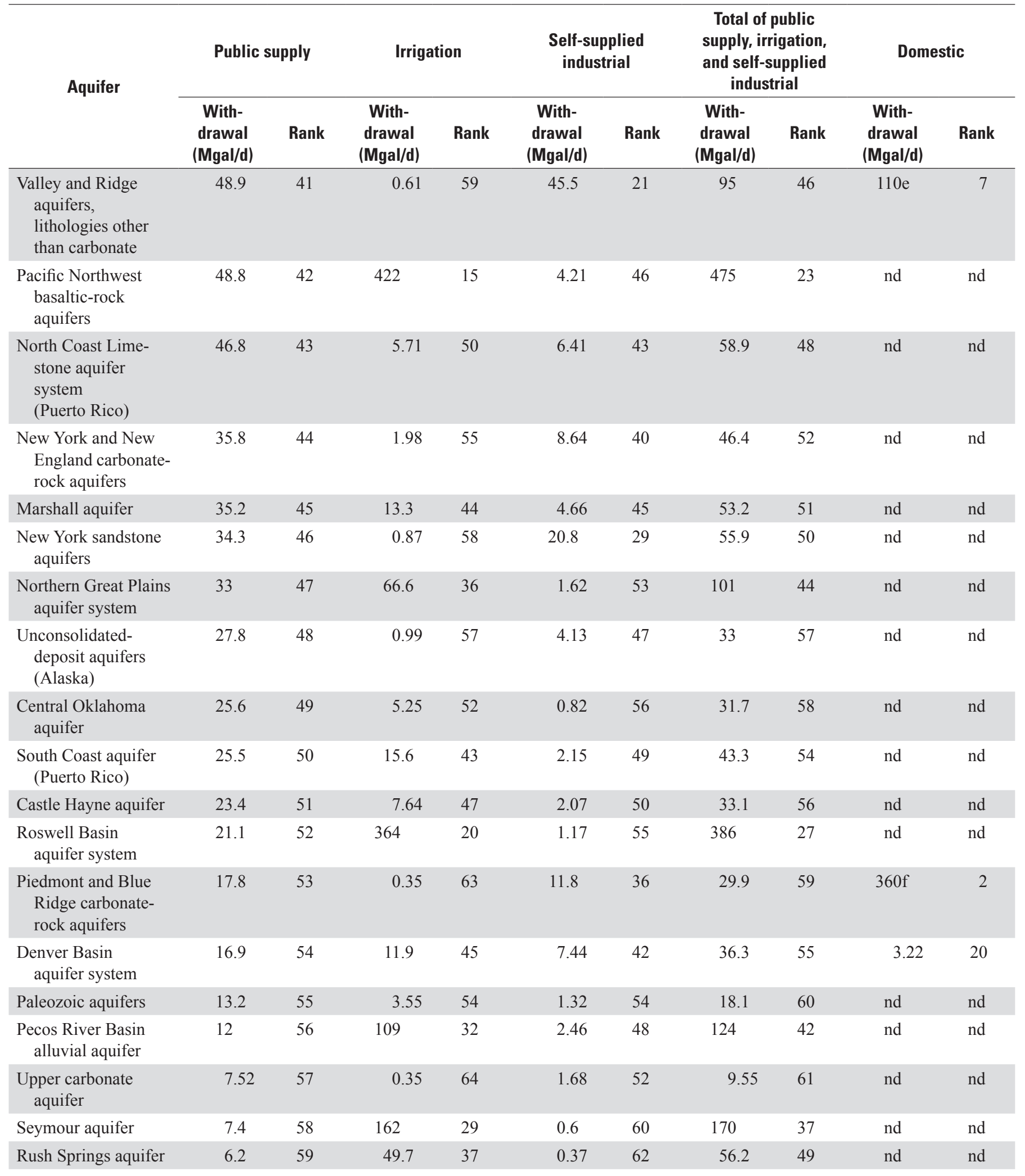


Table 2-1. Water withdrawals from principal aquifers for public supply and other uses. - Continued

[Water withdrawals for public supply, irrigation, and self-supplied industrial use are from Maupin and Barber (2005), adjusted for stream-valley aquifer withdrawals from Sargent and others (2008), for year 2000. Water withdrawals for domestic use are from Maupin and Arnold (2010) for year 2005. Individual uses may not sum to totals because of rounding. Aquifers are listed in order of decreasing withdrawals for public supply. Mgal/d, million gallons per day; nd, not determined]

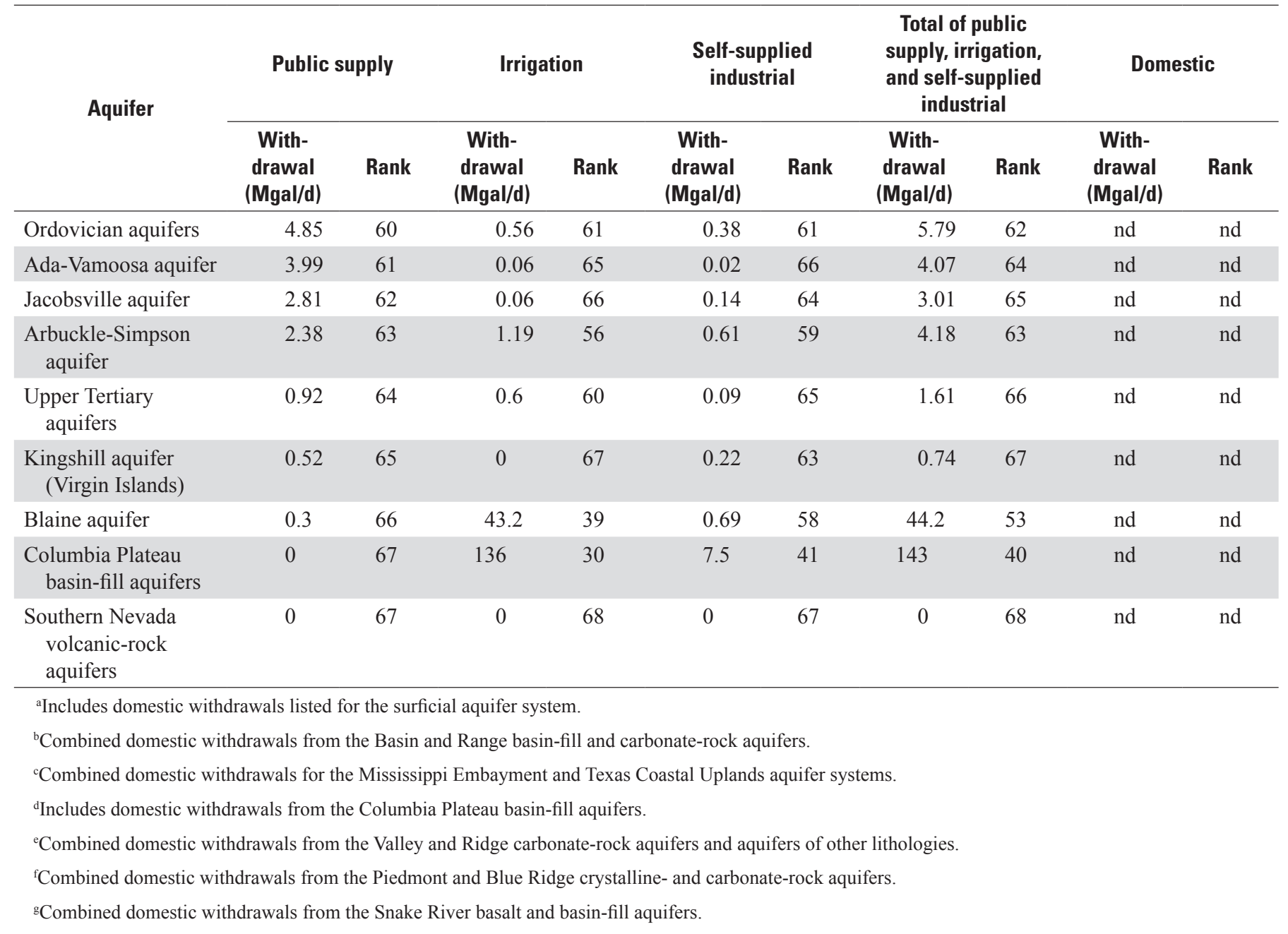

\section{References Cited}

Maupin, M.A., and Arnold, T.L., 2010, Estimates for self-supplied domestic withdrawals and population served for selected principal aquifers, calendar year 2005: U.S. Geological Survey Open-File Report 2010-1223, 10 p., accessed January 4, 2016, at http://pubs.usgs.gov/of/2010/1223/.

Maupin, M.A., and Barber, N.L., 2005, Estimated withdrawals from principal aquifers in the United States, 2000:

U.S. Geological Survey Circular 1279, 46 p., accessed

January 4, 2016, at http://pubs.usgs.gov/circ/2005/1279/.

Sargent, B.P., Maupin, M.A., and Hinkle, S.R., 2008,

Estimated withdrawals from stream-valley aquifers and refined estimated withdrawals from selected aquifers in the United States, 2000: U.S. Geological Survey Scientific Investigations Report 2008-5003, 71 p., accessed January 4, 2016, at http://pubs.usgs.gov/sir/2008/5003/. 


\section{Appendix 3. Quality-Control Data and Analysis of Blank Samples}

\section{Samples}

Quality-control (QC) samples were collected along with the environmental groundwater samples during the sampling period May 2012 through December 2013. These QC samples included equipment blanks, source solution blanks, field blanks, replicates, field spikes, and laboratory spikes. Waterquality data from the blank and replicate samples are included in this report along with a summary of detections in field blank samples (table 3-1). No analysis was made of the replicate data, but the data are provided in this report. Water-quality data from spike samples collected during the same period are not included in this report; it is anticipated that QC data from spike samples will be analyzed in subsequent data-series reports. Data from blank samples are provided in tables 3-2 through 3-8; and data from replicate samples are provided in tables 3-9 through 3-15.
Blank samples are QC samples that are used to determine if water samples might become contaminated during sample collection, field processing, transport, or laboratory analysis. Blank samples are collected using blank water that has been prepared to be free of detectable concentrations of the constituents of interest. An equipment blank generally is collected in a controlled environment (such as a laboratory) before field sampling begins and is intended to evaluate the suitability of the equipment and equipment cleaning protocols for the established data-quality requirements. A field blank is subjected to all the same aspects of sample collection, field processing, preservation, transportation, and laboratory handling as an environmental sample and is intended to evaluate the potential for these procedures to be sources of contamination. A source solution blank is a sample of the water used to collect the equipment and field blanks and is intended to verify

Table 3-1. Summary of results for field blanks collected by the National Water-Quality Assessment Project from May 2012 to December 2013.

[VOCs, volatile organic compounds; DOC, dissolved organic carbon; HHB, human-health benchmark; SMCL, secondary maximum contaminant level]

\begin{tabular}{|c|c|c|c|c|c|}
\hline Type of summary & $\begin{array}{c}\text { Major and } \\
\text { minor elements }\end{array}$ & $\begin{array}{l}\text { Trace } \\
\text { elements }\end{array}$ & $\begin{array}{l}\text { Nutrients } \\
\text { and DOC }\end{array}$ & VOCs & $\begin{array}{l}\text { Pesticide } \\
\text { compounds }\end{array}$ \\
\hline Total number of blank samples & 53 & 120 & 156 & 184 & 56 \\
\hline Number of field blanks & 53 & 49 & 87 & 66 & 56 \\
\hline $\begin{array}{l}\text { Number of constituents } \\
\text { analyzed }\end{array}$ & 10 & 22 & 6 & 136 & 285 \\
\hline $\begin{array}{l}\text { Number of constituents } \\
\text { detected in field blanks }\end{array}$ & 5 & 14 & 5 & 21 & 13 \\
\hline $\begin{array}{l}\text { Number of constituents } \\
\text { detected in field blanks } \\
\text { that have an HHB }\end{array}$ & 1 & 12 & 2 & 11 & 10 \\
\hline $\begin{array}{l}\text { Number of constituents } \\
\text { detected in field blanks } \\
\text { that have an SMCL }\end{array}$ & 2 & 4 & 0 & 0 & 0 \\
\hline $\begin{array}{l}\text { Largest ratio of the maximum } \\
\text { concentration in a field } \\
\text { blank to the corresponding } \\
\text { HHB, in percent }\end{array}$ & 0.50 & 1.90 & 0.70 & 2.00 & 0.06 \\
\hline $\begin{array}{l}\text { Largest ratio of the maximum } \\
\text { concentration in a field } \\
\text { blank to the corresponding } \\
\text { SMCL, in percent }\end{array}$ & 3.40 & 3.30 & Not applicable & Not applicable & Not applicable \\
\hline
\end{tabular}


that the blank water itself has no detectable concentrations of the constituents of interest. Because field blanks are collected under conditions most comparable to conditions affecting environmental samples, these blanks are most directly representative of potential sources of contamination to environmental samples and were the focus of this initial evaluation of blank-sample results.

Results of the initial evaluation of data from field blanks for major and trace elements, nutrients, volatile organic compounds (VOCs), and pesticide compounds are presented in this report. About 75 to 85 percent of the field blanks for each of these constituents were associated with groundwater sites that are sampled using a dedicated pump (primarily publicsupply and domestic wells), and the rest were associated with groundwater sites that are sampled using a portable sampling pump (monitoring wells). The objective of this initial evaluation of field blanks was to determine if environmental concentrations of these constituents as reported by the National Water-Quality Laboratory are suitable for comparison to their corresponding human-health benchmarks (HHBs) or to U.S. Environmental Protection Agency (EPA) secondary maximum contaminant levels (SMCLs) if HHBs have not been established. The HHBs are a set of health-based comparison thresholds that include EPA maximum contaminant levels (MCLs), Health-Based Screening Levels (HBSLs), and Human Health Benchmarks for Pesticides (HHBPs). Further evaluation of results for blank samples, such as through methods used by Olsen and others (2010), Bender and others (2011), Fram and others (2012), or Davis and others (2014), would be needed to determine if inadvertent contamination of samples with certain constituents would affect the interpretation of environmental concentrations of those constituents for objectives other than those presented in this report.

\section{Blank Sample Counts}

The total number of blank samples and the number of field blanks collected for groundwater sites between May 2012 and December 2013 vary by constituent group (table $3-1$ ). Data for all blank samples are presented in tables 3-2 through $3-8$. All blank samples were analyzed using the corresponding laboratory methods listed in table 2 of this report. Of the 184 VOC blank samples, 28 were collected in 2012 and analyzed for an older analytical schedule using purge and trap gas chromatography/mass spectrometry (Gilliom and others, 2006; Zogorski and others, 2006); 156 were collected in 2013 and analyzed using the most recent analytical schedule and laboratory methods (purge and trap gas chromatography/mass spectrometry and heated purge and trap gas chromatography/ mass spectrometry). Of the 56 pesticide blank samples, 7 were collected in 2012 and analyzed for an older analytical schedule using gas chromatography/mass spectrometry; 49 were collected in 2013 and analyzed using the most recent analytical schedule and laboratory method (direct aqueous injection liquid chromatography tandem mass spectrometry).

\section{Constituent Concentrations in Blank Samples}

Of the 10 major and minor elements included in laboratory analysis, 5 were detected in at least 1 field blank (table 3-1). Only one of the detected major elements (fluoride) has an HHB (table 2); two of the detected major elements (fluoride and iron) have SMCLs. The maximum concentration for fluoride in a field blank was less than 1 percent of its corresponding HHB and SMCL. The maximum concentration for iron in a field blank was 3.4 percent of its corresponding SMCL.

Of the 22 trace elements included in laboratory analysis, 14 were detected in at least 1 field blank (table 3-1). Of the detected trace elements, 12 (antimony, barium, boron, cadmium, chromium, copper, lead, manganese, molybdenum, nickel, silver, and zinc) have HHBs (table 2); 4 of the detected trace elements (copper, manganese, silver, and zinc) also have SMCLs. For 10 of the 12 trace elements with HHBs, the maximum concentration measured in a field blank was less than 1 percent of the corresponding HHB; for the remaining 2 trace elements (antimony and lead), the maximum concentration was less than 2 percent of the HHB. For three of the four trace elements with SMCLs, the maximum concentration measured in a field blank was less than 1 percent of the corresponding SMCL; for the remaining trace element (manganese), the maximum concentration was 3.3 percent of the corresponding SMCL.

Of the five nutrients or groups of nutrients that the laboratory analyzes directly (as opposed to the nutrients with calculated results), four were detected in at least one field blank (table 3-1). Two of the detected nutrients (nitrite and nitrate) have HHBs (table 2); none have SMCLs. For each of the two nutrients with HHBs, the maximum concentration measured in a blank was less than 1 percent of the corresponding threshold.

Blank samples collected in 2012 were analyzed for 85 VOCs, and blank samples collected in 2013 were analyzed for 90 VOCs; the change in laboratory methods and constituent lists resulted in a total of 136 different VOCs being included in the overall dataset of blank results. A total of 21 VOCs were detected in at least 1 field blank, 2 constituents in 2012 and 20 additional constituents in 2013 (table 3-1), and 11 of these compounds (1,1-dichloroethene, 1,4-dichlorobenzene, benzene, carbon disulfide, dichloromethane, ethylbenzene, $\mathrm{m}$-xylene plus p-xylene, o-xylene, styrene, toluene, and trichloromethane) have HHBs (table 2). For 9 of the 11 VOCs with HHBs, the maximum concentration measured in a blank was less than 1 percent of the corresponding HHB threshold; for the remaining 2 VOCs (1,1-dichloroethene and dichloromethane), the maximum concentration was 2 percent or less of the corresponding HHB threshold.

Blank samples collected in 2012 were analyzed for 137 pesticides, and blank samples collected in 2013 were analyzed for 227 pesticides; the change in laboratory methods and constituents resulted in a total of 285 different pesticide compounds being included in the overall dataset of blank results. A total of 13 pesticide compounds were detected in at least 1 field blank (table 3-1), 10 of which have HHBs; and none 
have SMCLs. Only 1 constituent was detected in field blank samples from 2012 (metolachlor), and 13 constituents were detected in field blank samples from 2013 (atrazine, metolachlor, nicosulfuron, 2-Isopropyl-6-methyl-4-pyrimidinol, aldacarb, bromacil, cis-permethrin, demethyl fluometuron (DMFM), fipronil sulfone, metribuzin, oxamyl, propiconazole, and tebuthiuron). For all of the pesticide compounds with HHBs, the maximum concentration measured in a field blank was less than 0.1 percent of the corresponding threshold.
The maximum concentrations of major and minor ions, trace elements, nutrients, and VOCs in field blanks are all substantially less than the thresholds used by National WaterQuality Assessment Project to distinguish between low and moderate concentrations (50 percent of the HHB or SMCL for inorganic constituents, and 10 percent of the HHB for organic constituents); therefore, results of the field blank samples for all constituent groups indicate minimal potential for effects of contamination on the number of groundwater samples that would be classified as having moderate or high concentrations relative to current HHBs or SMCLs.

\section{Appendix Tables 3-2 through 3-15}

The American Standard Code for Information Interchange (ASCII) text files of tables 3-2 through 3-15 are available for download at http://dx.doi.org/10.5066/F7HQ3X18.

3-2. Nutrients and dissolved organic carbon in groundwater blank samples collected by the U.S. Geological Survey National Water-Quality Assessment Project, May 2012 through December 2013.

3-3. Major and minor ions in groundwater blank samples collected by the U.S. Geological Survey National Water-Quality Assessment Project, May 2012 through December 2013.

3-4. Trace elements in groundwater blank samples collected by the U.S. Geological Survey National Water-Quality Assessment Project, May 2012 through December 2013.

3-5. Volatile organic compounds (VOCs) in groundwater blank samples collected by the U.S. Geological Survey National Water-Quality Assessment Project, May 2012 through November 2012.

3-6. Volatile organic compounds (VOCs) in groundwater blank samples collected by the U.S. Geological Survey National Water-Quality Assessment Project, April 2013 through December 2013.

3-7. Pesticides in groundwater blank samples collected by the U.S. Geological Survey National Water-Quality Assessment Project, May 2012 through November 2012.

3-8. Pesticides in groundwater blank samples collected by the U.S. Geological Survey National Water-Quality Assessment Project, April 2013 through December 2013.

3-9. Nutrients and dissolved organic carbon in groundwater replicate samples collected by the U.S. Geological Survey National Water-Quality Assessment Project, May 2012 through December 2013.

3-10. Major and minor ions in groundwater replicate samples collected by the U.S. Geological Survey National Water-Quality Assessment Project, May 2012 through December 2013.

3-11. Trace elements in groundwater replicate samples collected by the U.S. Geological Survey National Water-Quality Assessment Project, May 2012 through December 2013.

3-12. Volatile organic compounds (VOCs) in groundwater replicate samples collected by the U.S. Geological Survey National Water-Quality Assessment Project, May 2012 through November 2012.

3-13. Volatile organic compounds (VOCs) in groundwater replicate samples collected by the U.S. Geological Survey National Water-Quality Assessment Project, April 2013 through December 2013.

3-14. Pesticides in groundwater replicate samples collected by the U.S. Geological Survey National Water-Quality Assessment Project, May 2012 through November 2012.

3-15. Pesticides in groundwater replicate samples collected by the U.S. Geological Survey National Water-Quality Assessment Project, April 2013 through December 2013. 


\section{References Cited}

Bender, D.A., Zogorski, J.S., Mueller, D.K., Rose, D.L., Martin, J.D., and Brenner, C.K., 2011, Quality of volatile organic compound data from groundwater and surface water for the National Water-Quality Assessment Program, October 1996-December 2008: U.S. Geological Survey Scientific Investigations Report 2011-5204, 128 p., accessed January 4, 2016, at http://pubs.usgs.gov/sir/2011/5204/.

Childress, C.J.O., Forman, W.T., Connor, B.F., and Maloney, T.J., 1999, New reporting procedures based on long-term method detection levels and some considerations for interpretations of water-quality data provided by the U.S. Geological Survey National Water Quality Laboratory: U.S. Geological Survey Open-File Report 99-193, 19 p., accessed January 4, 2016, at http://water.usgs.gov/owq/ OFR_99-193/index.html.

Davis, T.A., Olsen, L.D., Fram, M.S., and Belitz, Kenneth, 2014, Updated study reporting levels (SRLs) for trace-element data collected for the California Groundwater Ambient Monitoring and Assessment (GAMA) Priority Basin Project, October 2009-March 2013: U.S. Geological Survey Scientific Investigations Report 2014-5105, 52 p., accessed January 4, 2016, at http://dx.doi.org/10.3133/sir20145105.

Fram, M.S., Olsen, L.D., and Belitz, Kenneth, 2012, Evaluation of volatile organic compound (VOC) blank data and application of study reporting levels to groundwater data collected for the California GAMA Priority Basin Project, May 2004 through September 2010: U.S. Geological Survey Scientific Investigations Report 2012-5139, 94 p., accessed January 4, 2016, at http://pubs.usgs.gov/ $\operatorname{sir} / 2012 / 5139 /$.
Gilliom, R.J., Alley, W.M. and Gurtz, M.E., 1995, Design of the National Water-Quality Assessment Program: occurrence and distribution of water-quality conditions, U.S. Geological Survey Circular 1112, 33 p. accessed March 1, 2016, at https://pubs.er.usgs.gov/publication/cir1112.

Olsen, L.D., Fram, M.S., and Belitz, Kenneth, 2010, Review of trace-element field-blank data collected for the California Groundwater Ambient Monitoring and Assessment (GAMA) Program, May 2004-January 2008: U.S. Geological Survey Scientific Investigations Report 2009-5220, 47 p., accessed January 4, 2016, at http://pubs.usgs.gov/ sir/2009/5220/.

Zogorski, J.S., Carter, J.M., Ivahnenko, Tamara, Lapham, W.W., Moran, M.J., Rowe, B.L., Squillace, P.J., and Toccalino, P.L., 2006, The quality of our Nation's watersVolatile organic compounds in the Nation's groundwater and drinking-water supply wells: U.S. Geological Survey Circular 1292, 101 p., accessed January 4, 2016, at http:// pubs.usgs.gov/circ/circ1292/. 


\section{Appendix 4. Well Depth and Open Interval by Study Network}

Table 4-1. Well depth by study network

[PAS, principal aquifer study; LUS, land-use study; MAS, major aquifer study; ETN, enhanced trends network]

\begin{tabular}{|c|c|c|c|c|c|c|c|c|c|c|c|}
\hline \multirow{2}{*}{$\begin{array}{l}\text { Net- } \\
\text { work } \\
\text { type }\end{array}$} & \multirow[b]{2}{*}{$\begin{array}{l}\text { Network } \\
\text { name }\end{array}$} & \multirow{2}{*}{$\begin{array}{l}\text { Number of } \\
\text { wells in } \\
\text { network } \\
\text { with data } \\
\text { present- } \\
\text { ed in this } \\
\text { report }\end{array}$} & \multirow{2}{*}{$\begin{array}{c}\text { Number } \\
\text { of wells } \\
\text { with well } \\
\text { depth } \\
\text { data }\end{array}$} & \multicolumn{8}{|c|}{ Well depth, in feet } \\
\hline & & & & $\begin{array}{l}\text { Mini- } \\
\text { mum }\end{array}$ & $\begin{array}{l}\text { 10th } \\
\text { percent- } \\
\text { ile }\end{array}$ & $\begin{array}{l}\text { 25th } \\
\text { percent- } \\
\text { ile }\end{array}$ & Median & $\begin{array}{l}\text { 75th } \\
\text { percent- } \\
\text { ile }\end{array}$ & $\begin{array}{l}\text { 90th } \\
\text { percent- } \\
\text { ile }\end{array}$ & $\begin{array}{c}\text { Maxi- } \\
\text { mum }\end{array}$ & Mean \\
\hline PAS & bnrfpas1 & 78 & 78 & 83 & 210 & 382 & 522.5 & 790 & 1,035 & 1,450 & 575 \\
\hline PAS & clowpas1 & 60 & 58 & 115 & 250 & 345 & 537.5 & 802 & 1,104 & 2,542 & 659 \\
\hline PAS & glacpas1 & 69 & 68 & 27 & 44 & 65 & 90 & 148 & 223 & 430 & 122 \\
\hline PAS & nacppas1 & 74 & 73 & 61 & 219 & 309 & 439 & 552 & 706 & 1,800 & 481 \\
\hline PAS & nacppas2 & 59 & 58 & 0 & 121 & 205 & 278 & 375 & 680 & 995 & 328 \\
\hline PAS & secppas1 & 79 & 71 & 118 & 260 & 367 & 660 & 1,061 & 1,760 & 3,832 & 864 \\
\hline PAS & vpdcpas1 & 60 & 43 & 100 & 165 & 215 & 300 & 463 & 550 & 720 & 345 \\
\hline LUS & acfbluscr3 & 30 & 30 & 14 & 28 & 36 & 46 & 52 & 69 & 75 & 46 \\
\hline LUS & dlmvluscr1 & 25 & 25 & 9 & 13 & 15 & 21 & 23 & 27 & 34 & 20 \\
\hline LUS & gafllusrc1a & 9 & 9 & 19 & 19 & 22 & 28 & 38 & 39 & 39 & 30 \\
\hline LUS & gafllusrc1b & 15 & 15 & 14 & 33 & 38 & 53 & 100 & 150 & 250 & 77 \\
\hline LUS & nvbrlusrc1 & 27 & 27 & 14 & 15 & 20 & 39 & 130 & 149 & 176 & 67 \\
\hline LUS & sanjlusorla & 23 & 22 & 98 & 114 & 120 & 163 & 200 & 245 & 262 & 164 \\
\hline LUS & spltluscr1 & 27 & 27 & 12 & 13 & 17 & 22 & 33 & 47 & 93 & 27 \\
\hline MAS & albesus7 & 30 & 30 & 22 & 60 & 80 & 105 & 185 & 204 & 240 & 127 \\
\hline MAS & dlmvsus1 & 29 & 28 & 15 & 28 & 38 & 44 & 65 & 95 & 129.5 & 54 \\
\hline MAS & gaflsus4 & 26 & 26 & 109 & 230 & 280 & 431 & 610 & 700 & 800 & 452 \\
\hline MAS & wmicsus2 & 24 & 24 & 41 & 49 & 62 & 83.5 & 112 & 140 & 240 & 93 \\
\hline ETN & cvaletn1 & 3 & 3 & 234 & 234 & 234 & 320 & 620 & 620 & 620 & 391 \\
\hline ETN & edtretn1 & 3 & 3 & 300 & 300 & 300 & 550 & 1,500 & 1,500 & 1,500 & 783 \\
\hline ETN & metxetn1 & 2 & 2 & 90 & 90 & 90 & 357 & 624 & 624 & 624 & 357 \\
\hline
\end{tabular}


Table 4-2. Length of open interval by study network

[PAS, principal aquifer study; LUS, land-use study; MAS, major aquifer study; ETN, enhanced trends network]

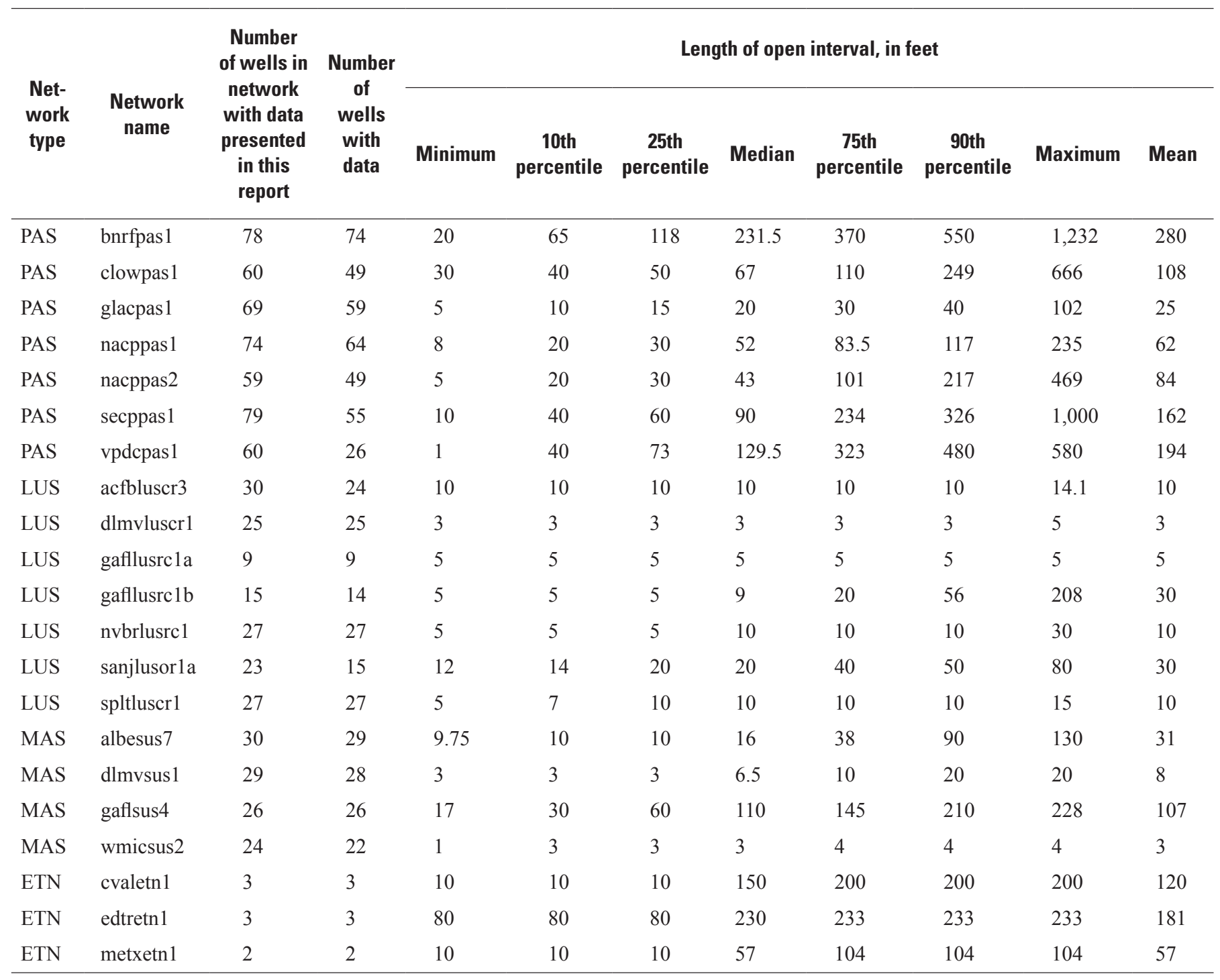





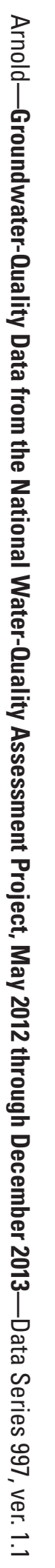

